FELIPE ROCHA

VIGILÂNCIA E CONTROLE DA RAIVA EM HERBÍVOROS SOB OS ASPECTOS DA BIOLOGIA DO Desmodus rotundus (E. GEOFFROY, 1810) E DA CIRCULAÇÃO DO VÍRUS DA RAIVA EM POPULAÇÕES SUSCEPTÍVEIS RELACIONADOS ÀS AÇÕES DO SERVIÇO VETERINÁRIO OFICIAL

São Paulo

2018 



\section{FELIPE ROCHA}

Vigilância e Controle da Raiva em Herbívoros sob os Aspectos da Biologia do Desmodus rotundus (E. Geoffroy, 1810) e da Circulação do Vírus da Raiva em Populações Susceptíveis Relacionados às Ações do Serviço Veterinário Oficial

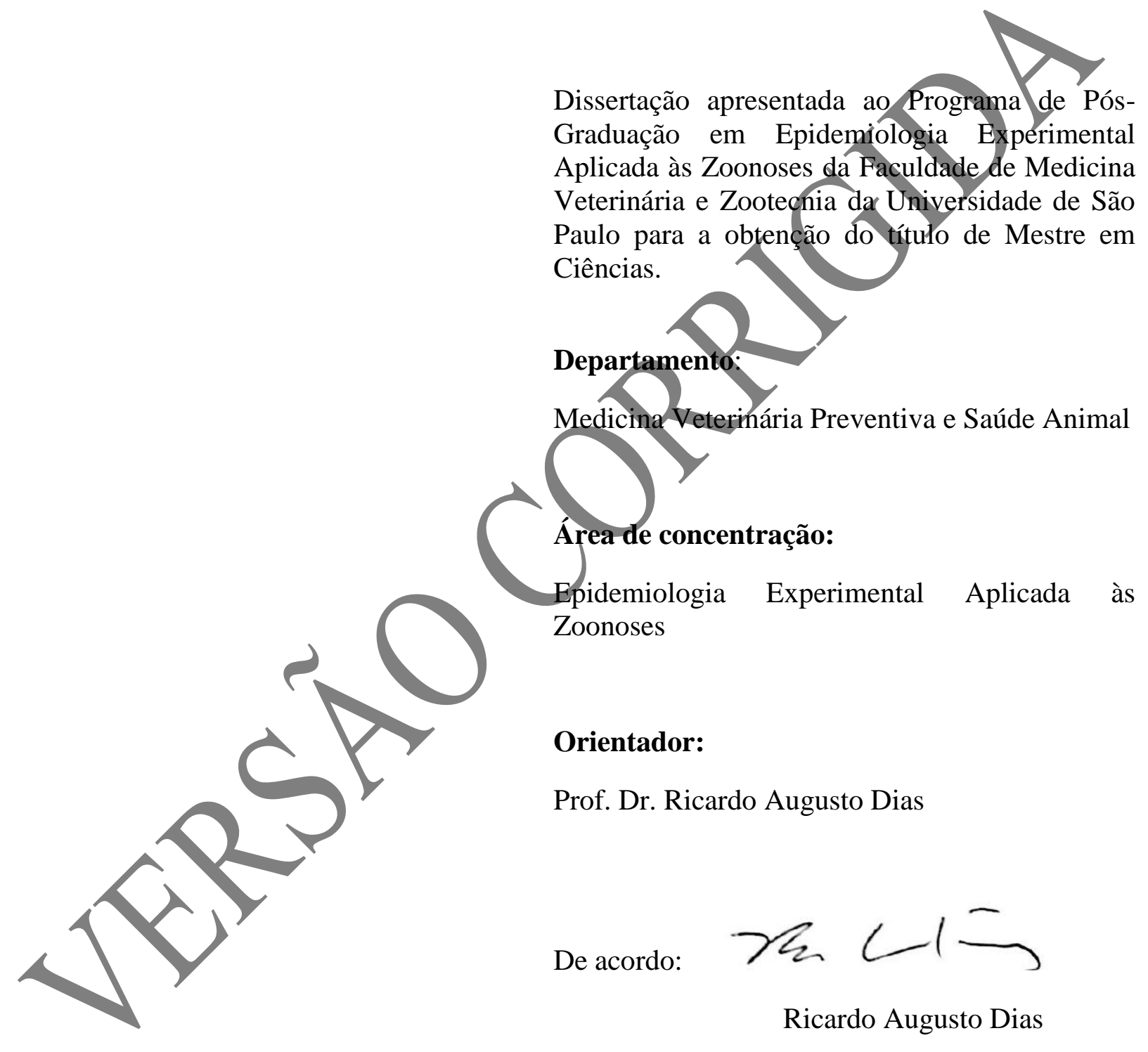

São Paulo

2018

Obs: A versão original encontra-se disponível na Biblioteca da FMVZ/USP 
Autorizo a reprodução parcial ou total desta obra, para fins acadêmicos, desde que citada a fonte.

\section{DADOS INTERNACIONAIS DE CATALOGAÇÃO NA PUBLICAÇÃO}

(Biblioteca Virginie Buff D’Ápice da Faculdade de Medicina Veterinária e Zootecnia da Universidade de São Paulo)

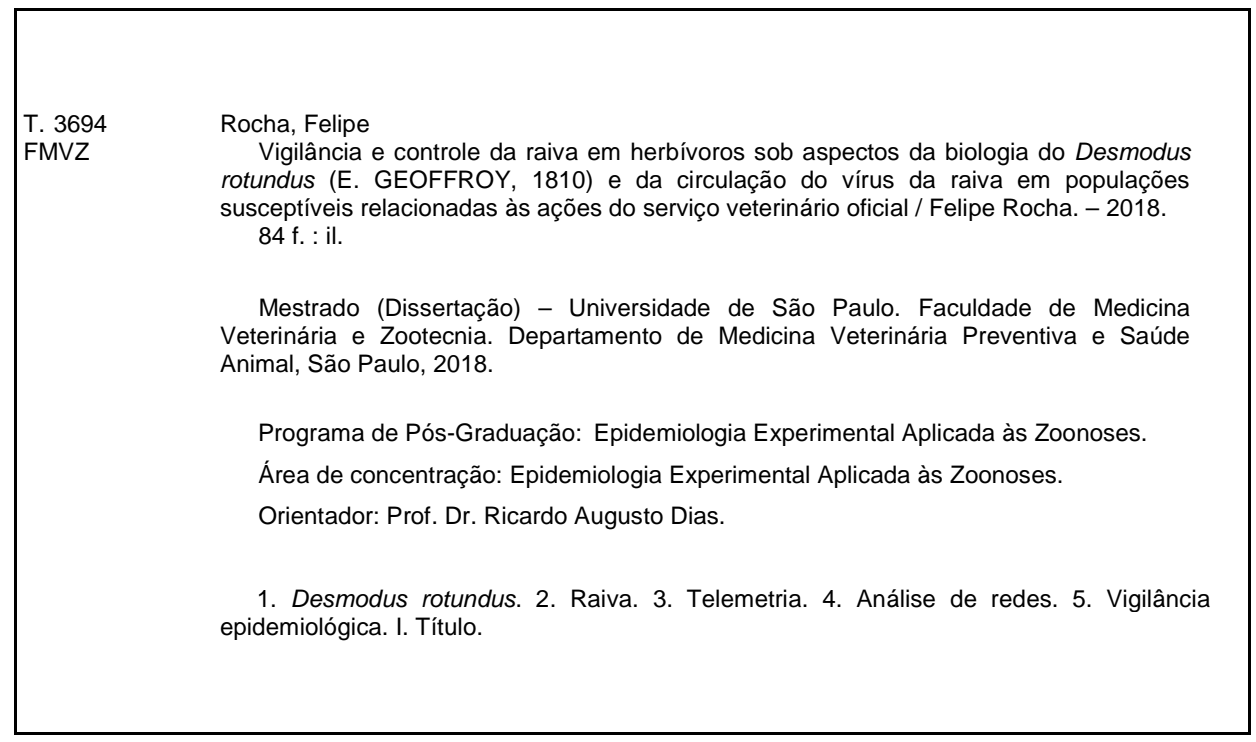

Ficha catalográfica elaborada pela bibliotecária Maria Aparecida Laet, CRB 5673-8, da FMVZ/USP. 


\section{CERTIFICADO}

Certificamos que a proposta intitulada "Biologia do Desmodus Rotundus (E. Geoffroy, 1810) e circulaçăo do vírus da raiva em populações susceptíveis de herbívoros de interesse econômico: efeitos nas ações de vigilância e controle da raiva desenvolvidas pelo serviço veterinário oficial*", protocolada sob o CEUA $n^{2} 3177210115$ (ID 001609), sob a responsabilidade de Ricardo Augusto Dias e equipe; Francisco Miroslav Ullioa Stanojlovic - que envolve a produçăo, manutençằo e/ou utilizaçăo de animais pertencentes ao filo Chordata, subfilo Vertebrata (exceto o homem), para fins de pesquisa cientifica ou ensino - está de acordo com os preceitos da Lei 11.794 de 8 de outubro de 2008, com o Decreto 6.899 de 15 de julho de 2009, bem como com as normas editadas pelo Conselho Nacional de Controle da Experimentaçăo Animal (CONCEA), e foi aprovada pela Comissăo de Ética no Uso de Animais da Faculdade de Medicina Veterinária e Zootecnia da Universidade de São Paulo (CEUA/FMVZ) na reunião de 13/10/2015.

We certify that the proposal "Desmodus rotundus(E. Geoffroy, 1810) biology and circulation of the rabies virus in susceptible populations of herbivores of economic interest: effects on surveillance and control of rabies carried by the official veterinary service*, utilizing 60 Brazilian wild species (30 males and 30 females), protocol number CEUA 3177210115 (10 001609), under the responsibility of Ricardo Augusto Dias and team; Francisco Miroslav Uiloa Stanojlovic - which involves the production, maintenance and/or use of animals belonging to the phylum Chordata, subphylum Vertebrata (except human beings), for scientific research purposes or teaching - is in accordance with Law 11.794 of October 8, 2008, Decree 6899 of July 15, 2009, as well as with the rules issued by the National Council for Control of Animal Experimentation (CONCEA), and was approved by the Ethic Committee on Animal Use of the School of Veterinary Medicine and Animal Science (University of Săo Paulo) (CEUA/FMVZ) in the meeting of $10 / 13 / 2015$.

Finalidade da Proposta: Pesquisa

Vigência da Proposta: de 03/2015 a 04/2017_Área: Medicina Veterinária Preventiva E Saúde Animal

\begin{tabular}{|c|c|c|c|c|c|c|c|}
\hline Origem: & Nắo aplicável biotério & & & & & & \\
\hline Espécie: & Espécies silvestres brasileiras & sexo: & Fêmeas & idade: & a & N: & 30 \\
\hline Linhagem: & Quirópteros & & & Peso: & a & & \\
\hline Origem: & Nằo aplicável biotério & & & & & & \\
\hline Espécie: & Espécies silvestres brasileiras & sexo: & Machos & idade: & a & N: & 30 \\
\hline Linhagem: & Quirópteros & & & Peso: & a & & \\
\hline
\end{tabular}

Registro IBAMA/Sisbio/Etc:

Método de Captura: Os morcegos serăo capturados segundo preconizado por Kunz et al. (2009).

Local do experimento:

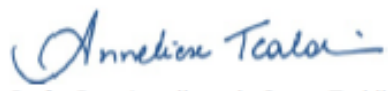

Profa. Dra. Anneliese de Souza Traldi Presidente da Comissăo de Ética no Uso de Animais Faculdade de Medicina Veterinária e Zootecnia da Universidade Faculdade de Medicina Veterinária e Zootecnia da Universidade de Săo Paulo

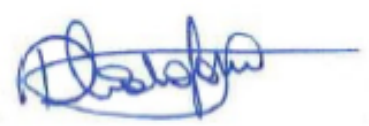

Roseli da Costa Gomes Secretária de Săo Paulo 
Ministério do Meio Ambiente - MMA

Instituto Chico Mendes de Conservaçäo da Biodiversidade - ICMBio

Sistema de Autorização e Informação em Biodiversidade - SISBIO

\section{Autorização para atividades com finalidade cientifica}

\begin{tabular}{|c|c|c|}
\hline Número: 47355-1 & Data da Emissão: 21/01/2015 15:44 & Data para Revalidação*: 20/02/2016 \\
\hline
\end{tabular}

Dados do titular

\begin{tabular}{|l|l|l|l|l|l}
\hline Nome: Ricardo Augusto Dias & CPF: $162.510 .648-38$
\end{tabular}

Título do Projeto: BIOLOGIA DO DESMODUS ROTUNDUS (E. GEOFFROY, 1810) E CIRCULAÇÃO DO VÍRUS DA RAIVA EM POPULAÇÕES SUSCEPTIVEIS DE HERBIVOROS DE INTERESSE ECONÔMCO: EFEITOS NAS AÇŌES DE VIGILÁNCIA E CONTROLE DA RAIVA DESENVOLVIDAS PELO SERVÇO VETERINÁRIO OFICIAL

\begin{tabular}{|l|l|}
\hline Nome da Instituiçäo : Faculdade de Medicina Veterinária e Zootecnia USP & CNPJ: 63.025.530/0019-33 \\
\hline
\end{tabular}

Cronograma de atividades

\begin{tabular}{|c|c|c|c|}
\hline \# & Descricaro da ativicade & Inicio (més/ano) & Fim (més/ano) \\
\hline 1 & Elarocraça de apllcativo de celular & $12 / 2014$ & 0372015 \\
\hline 2 & Seleç30 das propioned $3 d e s$ & $05 / 2015$ & $03 / 2015$ \\
\hline 3 & Sensibulzacáb dos proorietarios & $03 / 2015$ & $03 / 2015$ \\
\hline 4 & Captura e teremetria de moroggos com GPS & $04 / 2015$ & $12 / 2015$ \\
\hline$\frac{5}{5}$ & Acompanhamento de espolabcho e suspelizs de ralva em herolvoros & $04 / 2015$ & 1172016 \\
\hline 5 & Annostragen de morcegos & $05 / 2015$ & 102016 \\
\hline 7 & Anallse 006 dad06 & $70 / 2015$ & 1222017 \\
\hline
\end{tabular}

Observações e ressalvas



materials, tendo por objeto coletar dados, materials, especimes blologloos e minerals, pegas integrantes da cultura nativa e cultura popular, presente e passada

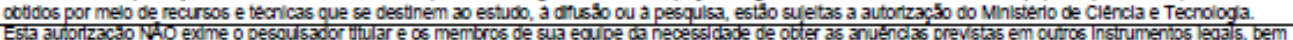

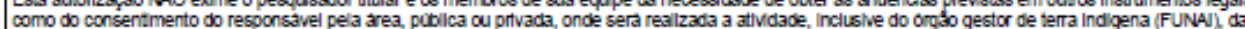

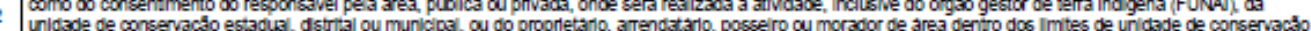
federal culo processo de reqularizaç5o fundaria encontra-se em curso.

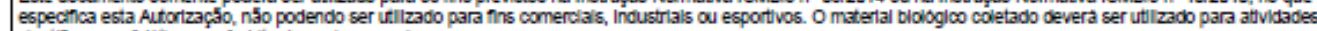
clentiflczs ou ddatcas no ambito do ensino superior.

4 Loenca para importaç5o ou exportaça de fora e fauna - CITES e nకo CITES.

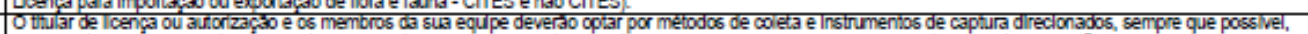

5 a gupo taxonomico de interesse, evitando a morie ou dano significativo a outros grupos; e empregar esforço de coleta ou captura que náo comprometa a viablidade



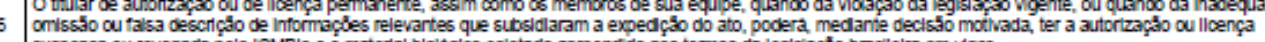

suspensa ou revogada pelo ICMElo e o material biologloc coletado acreendido nos temos da legisiaça brasleelra em vigor.

plataforma continental e na zona economica excusiva, ou ac coninecimento tradlidonal assodado ao pastimonio genetico, para fins de pesquisa clentinca,

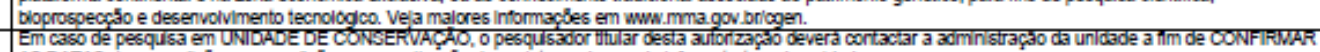



Outras ressalvas

- Caso haja atividades em cavicades naturais subterraneas a captura de morcegos com a uti zaçá de redes de nebinas devera ocorrer apenas

nas proximidades das entradas, nunca no interior das cavernas; sua entrada principal e na maior precisăo possivel, atentando para o registro do datum utilizado, do número de satélites e erro associados aos pontos coletados.

Este documento (Autorização para atividades com finalidade científica) foi expedido com base na Instruçäo Normativa n 03/2014. Através do código de autenticação abaixo, qualquer cidadão poderá verificar a autenticidade ou regularidade deste documento, por meio da página do Sisbio/lCMBio na Internet (uww.icmbio.gov.brisisbio)

Código de autenticação: 92998917

Página 1/4 
Autorização para atividades com finalidade científica

\begin{tabular}{|c|c|c|}
\hline Número: $47355-1$ & Data da Emissão: 21/01/2015 15:44 & Data para Revalidação*: 20/02/2016 \\
\hline 'De acordo com o art 28 da IN 03/2014, esta autorização tem prazo de validade equivalente ao previsto no cronograma de atividades do projeto, \\
mas deverá ser revalidada anualmente mediante a apresentaçấ do relatónio de atividades a ser enviado por meio do Sisbio no prazo de até 30 dias \\
a contar da data do aniversário de sua emissäo.
\end{tabular}

Dados do titular

\begin{tabular}{|l|l|l|l|l}
\hline Nome: Ricardo Augusto Dias & CPF: $182.510 .648-38$
\end{tabular}

Título do Projeto: BIOLOGIA DO DESMODUS ROTUNDUS (E. GEOFFROY, 1810) E CIRCULAÇÃO DO VíRUS DA RAIVA EM POPULAÇÕES SUSCEPTIVEIS DE HERBIVOROS DE INTERESSE ECONÔMICO: EFEITOS NAS AÇÕES DE VIGILANACIA E CONTROLE DA RAIVA DESENVOLVIDAS PELO SERVIÇO VETERINÁRIO OFICIAL

Nome da Instituiçäo : Faculdade de Medicina Veterinária e Zootecria USP

CNPJ: $63.025 .530 / 0019-33$

2 U membro de nacionalidade estrangelra Francisco Miroslav Ulloa Stanojowc, possul o Vnculo de Programa de bolsas ou auxilio a pesquisa patrocinado pela FAPESP, estando dispensado de autorizaçäo do Ministério da Ciência. Tecnologia e lnovaçâo.

Equipe

\begin{tabular}{|c|c|c|c|c|c|}
\hline$\#$ & Name & Funçso & CPF & Doc. Identdade & 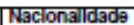 \\
\hline it & 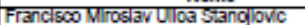 & colsodrador & $235.325 .600-28$ & V7972320 DPF-SP & Estrangera \\
\hline 2 & Gabriel Prohaska Bichettl & Colizoorador & $423.497 .798-58$ & 382297039 sSp-SP & Erasselera \\
\hline 3 & Izabel Carolina Vargas Pinto Gogone & Colsooradora & $318.099 .648-05$ & 255493897 GSP-SP & Eraslelira \\
\hline
\end{tabular}

Locais onde as atividades de campo serão executadas

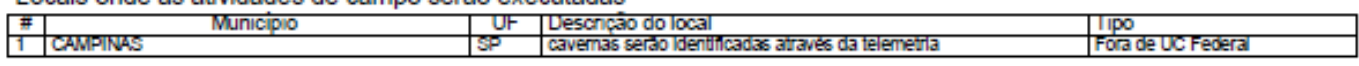

Atividades $X$ Táxons

\begin{tabular}{|c|c|c|}
\hline \# & Abvidade & Taxons \\
\hline 1 & Capotura de anlmals slvestres In stiv & Desmodus rohundus \\
\hline 2 & coletaltransoorie de amostras biolocicas In situ & Desmodus rotundus \\
\hline 3 & Marcaçăo de animais sivestres in situ & Desmodus rotundus \\
\hline
\end{tabular}

Material e métodos

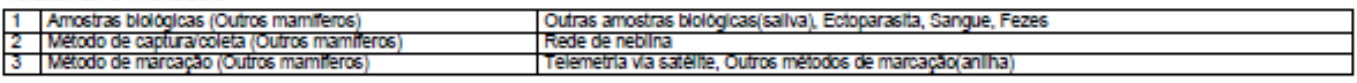

Destino do material biológico coletado

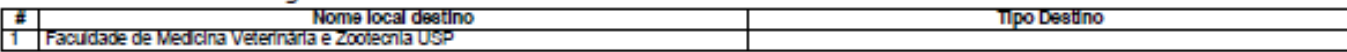

Este documento (Autorização para atividades com finalidade cientifica) foi expedido com base na Instruçäo Normativa $n^{\circ} 03 / 2014$. Através do código de autenticação abaixo, qualquer cidadão poderá verificar a autenticidade ou regularidade deste documento, por meio da página do Sisbio/lCMBio na Internet (www.icmbio.gov.brisisbio)

Código de autenticação: 92998917

Página 2/4 
Ministério do Meio Ambiente - MMA

Instituto Chico Mendes de Conservação da Biodiversidade - ICMBio

Sistema de Autorização e Informação em Biodiversidade - SISBIO

Autorização para atividades com finalidade científica

\begin{tabular}{|c|c|c|}
\hline \multicolumn{1}{|c|}{ Número: $47355-1$} & Data da Emissão: 21/01/2015 15:44 & \multicolumn{1}{c|}{ Data para Revalidação*: 20/02/2016 } \\
\hline "De acordo com o art. 28 da IN 03/2014, esta autorizaçäo tem prazo de validade equivalente ao previsto no cronograma de atividades do projeto, \\
mas deverá ser revalidada anualmente mediante a apresentação do relatório de atividades a ser enviado por meio do Sisbio no prazo de até 30 dias \\
a contar da data do aniversário de sua emissäo.
\end{tabular}

\section{Dados do titular}

\begin{tabular}{|l|l|l|l|l|l|}
\hline Nome: Ricardo Augusto Dias & CPF: $162.510 .648-38$
\end{tabular}

Título do Projeto: BIOLOGIA DO DESMODUS ROTUNDUS (E. GEOFFROY, 1810) E CIRCULAÇÃO DO VíRUS DA RAIVA EM POPULAÇÕES SUSCEPTIVEIS DE HERBIVOROS DE INTERESSE ECONÔMCO: EFEITOS NAS AÇÕES DE VIGILÁNCIA E CONTROLE DA RAINA DESENVOLVIDAS PELO SERVIÇO VETERINÁRIO OFCIAL

Nome da Instituiçäo : Faculdade de Medicina Veterinária e Zootecnia USP CNPJ: 63.025.530/0019-33

\section{Registro de coleta imprevista de material biológico}

De acordo com a Instrução Normativa $n^{\circ}$ 03/2014, a coleta imprevista de material biológico ou de substrato não contemplado na autorização ou na licença permanente deverá ser anotada na mesma, em campo específico, por ocasião da coleta, devendo esta coleta imprevista ser comunicada por meio do relatório de atividades. $O$ transporte do material biológico ou do substrato deverá ser acompanhado da autorização ou da licença permanente com a devida anotação. O material biológico coletado de forma imprevista, deverá ser destinado à instituição científica e, depositado, preferencialmente, em coleção biológica cientifica registrada no Cadastro Nacional de Coleções Biológicas (CCBIO).

\begin{tabular}{|c|c|c|c|c|}
\hline Táxon" & Qtdole. & Tpo de amostra & Qtole. & Data \\
\hline & & & & \\
\hline & & & & \\
\hline & & & & \\
\hline & & & & \\
\hline & & & & \\
\hline & & & & \\
\hline & & & & \\
\hline & & & & \\
\hline & & & & \\
\hline & & & & \\
\hline & & & & \\
\hline
\end{tabular}

Este documento (Autorizaçäo para afividades corn finalidade científica) foi expedido com base na Instruçäo Normativa n 03/2014. Através do código de autenticaçäo abaixo, qualquer cidadão poderá verificar a autenticidade ou regularidade deste documento, por meio da página do Sisbio/lCMBio na Internet (uww.icmbio.gov.brisisbio)

Código de autenticação: 92998917 
Ministério do Meio Ambiente - MMA

Instituto Chico Mendes de Conservaçäo da Biodiversidade - ICMBio

Sistema de Autorização e Informação em Biodiversidade - SISBIO

\section{Autorização para atividades com finalidade científica}

\begin{tabular}{|l|l|l}
\hline Número: 47355-1 & Data da Emissão: 21/01/2015 15:44 & Data para Revalidação*: 20/02/2016
\end{tabular}

" De acordo com o art. 28 da IN 03/2014, esta autorizacăo tem prazo de validade equivalente ao previsto no cronograma de atividades do projeto, mas deverá ser revalidada anualmente mediante a apresentaçâo do relatório de atividades a ser enviado por meio do Sisbio no prazo de até 30 dias a contar da data do aniversário de sua emissäo.

Dados do titular

\begin{tabular}{|l|l|l|l|l|l|}
\hline Nome: Ricardo Augusto Dias & CPF: $162.510 .648-38$
\end{tabular}

Título do Projeto: BIOLOGIA DO DESMODUS ROTUNDUS (E. GEOFFROY, 1810) E CIRCULAÇÃO DO VÍRUS DA RAIVA EM POPULAÇÕES SUSCEPTIVEIS DE HERBIVOROS DE INTERESSE ECONÔMICO: EFEITOS NAS AÇÕES DE VIGILÁNCIA E CONTROLE DA RAIVA DESENVOLVIDAS PELO SERVICO VETERINÁRIO OFICIAL

Nome da Instituiçäo : Faculdade de Medicina Veterinária e Zootecria USP

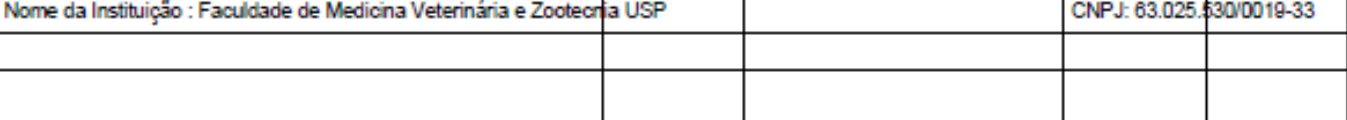

"Ident ficar o espécine no nivel taxonómico possivel.

Este documento (Autorização para atividades com finalidade científica) foi expedido com base na Instruçäo Normativa n 03/2014. Através do código de autenticaçăo abaixo, qualquer cidadão poderá verificar a autenticidade ou regularidade deste documento, por meio da página do Sisbio/lCMBio na Internet (www.icmbio.gov.brisisbio).

Código de autenticação: 92998917

Página 4/4 


\section{FOLHA DE AVALIAÇÃO}

Autor: ROCHA, Felipe

Título: Vigilância e controle da raiva em herbívoros sob aspectos da biologia do Desmodus rotundus (E. GEOFFROY, 1810) e da circulação do vírus da raiva e, populações susceptíveis relacionadas às ações do serviço veterinário oficial.

Dissertação apresentada ao Programa de Pós-Graduação em Epidemiologia Experimental Aplicada às Zoonoses da Faculdade de Medicina Veterinária e Zootecnia da Universidade de São Paulo para obtenção do título de Mestre em Ciências

Data

\section{Banca Examinadora}

Prof Dr.:

Instituição: Decisão:

Prof Dr.: Instituição: Decisão:

Prof Dr.: Instituição: Decisão: 


\section{AGRADECIMENTOS}

Ao CNPq pelo apoio financeiro ao projeto realizado.

O presente trabalho foi realizado com apoio da Coordenação de Aperfeiçoamento de Pessoal de Nível Superior - Brasil (CAPES) - Código de Financiamento 001.

À toda equipe da CDA, em especial ao Dr. Paulo Fadil, ao Dr. José Irineu Silva, à Dra. Ana Paula Belchior, ao Dr. Francisco Eugenio Souza Reis e à toda equipe do EDA de Guaratinguetá, por todo o apoio e suporte para realização deste trabalho.

À equipe do Laboratório de Biologia Molecular Aplicada e Sorologia (LABMAS), em especial ao Prof. Dr. Paulo Brandão e ao doutorando Washinton Carlos Agostino, por todo auxílio na realização deste trabalho.

Ao Danival e à toda equipe da secretaria do LEB, por toda dedicação e atenção dada a todos os alunos do departamento.

Aos amigos Daniel, Jason e José Grisi por toda ajuda e ensinamentos passados durante essa jornada, vocês me ajudaram muito.

Ao Van, ao Dan e à turma, pelos longos anos de amizade, por sempre comparecerem quando precisei de apoio.

Ao Júlio e à Monica por me darem o empurrão que precisava para iniciar esta jornada e por todos os conselhos que carrego com carinho.

Aos companheiros de campo Francisco, Vanessa e Vinícius pelas horas dentro do carro rodando pelas zonas rurais de Guaratinguetá e dentro de cavernas e bueiros em busca de morcegos.

Ao Alvaro e à Liria, por me receberam em sua casa e me tratarem como um filho.

Ao meu irmão, Fernando, por ser um exemplo de perseverança para mim.

Aos meus pais, Milton e Renata, pela vida que me deram.

À Samantha Valadas, por todo amor que me dedica.

Ao Prof. Dr. Ricardo Augusto Dias, por ter sido mais que um orientador, um irmão mais velho.

A todos que contribuíram, de forma direta ou indireta, para a conclusão desta dissertação. 


\section{RESUMO}

ROCHA, F. Vigilância e controle da raiva em herbívoros sob aspectos da biologia do Desmodus rotundus (E. GEOFFROY, 1810) e da circulação do vírus da raiva em populações susceptíveis relacionadas às ações do serviço veterinário oficial. 2018. 88 f. Dissertação (Mestrado em Ciências) - Faculdade de Medicina Veterinária e Zootecnia, Universidade de São Paulo, São Paulo, 2018.

A importância do morcego hematófago Desmodus rotundus para a manutenção do vírus da raiva no meio rural não reside unicamente em sua capacidade de transmitir esta enfermidade para animais de produção, mas também na sua capacidade de adaptação às mudanças ambientais e climáticas, concedendo-lhe uma ampla distribuição geográfica. Métodos de controle e vigilância para esta enfermidade foram criados baseando-se no conhecimento empírico acumulado sobre a transmissão do vírus pelos morcegos hematófagos. Esta abordagem, no entanto, tem se mostrado insuficiente para controlar adequadamente a doença em animais de produção, tendo sido observado um aumento no número de casos notificados nos últimos anos. No presente trabalho, foram descritos os padrões de uso do espaço por estes morcegos por meio de monitoramento por rádio-telemetria. Com base nos resultados obtidos, somados aos conhecimentos científicos disponíveis, construiu-se um modelo de transmissão incorporando determinantes geográficos e comportamentais do morcego hematófago com o intuito de direcionar e otimizar as ações de vigilância epidemiológica e controle da transmissão da raiva. Uma rede do tipo bimodal foi construída, composta pela integração entre uma rede de contato entre abrigos de morcegos hematófagos e outra, de contato entre estes abrigos e propriedades rurais criadoras de herbívoros de interesse econômico. $O$ modelo resultante demonstra maior significância da rede entre abrigos para a manutenção e transmissão do vírus, além da correlação entre topografia e espoliação. O modelo foi capaz de identificar comunidades de propriedades rurais sob risco para a ocorrência de raiva e em que comunidades de abrigos o vírus se mantem circulando. $O$ entendimento das interações entre morcegos e suas fontes de alimentação, influenciadas pelo ambiente, permite estabelecer medidas de vigilância e controle mais precisas e, em última instância, com uma menor relação de custo-benefício destas ações.

Palavras-chave: Desmodus rotundus. Raiva. Telemetria. Análise de redes. Vigilância epidemiológica. 


\section{ABSTRACT}

ROCHA, F. Rabies surveillance and control in herbivores by biological aspects of the Desmodus rotundus (E. GEOFFROY, 1810) and the rabies virus circulation in susceptible populations related to the actions of the official veterinary service. [Vigilância e controle da raiva em herbívoros sob aspectos da biologia do Desmodus rotundus (E. GEOFFROY, 1810) e da circulação do vírus da raiva em populações susceptíveis relacionadas às ações do serviço veterinário oficial.] 2018. $88 \mathrm{f}$. Dissertação (Mestrado em Ciências) - Faculdade de Medicina Veterinária e Zootecnia, Universidade de São Paulo, São Paulo, 2018.

The importance of the hematophagous bat Desmodus rotundus for the maintenance of the rabies virus in the rural environment is not only related to its ability to transmit this disease to livestock, but also in its capacity for adaptation to the environmental and climatic changes, granting them a wide geographic distribution. Control and surveillance methods for this disease were created based on the accumulated empirical knowledge about the transmission of the virus by hematophagous bats. This approach, however, has proved insufficient to adequately control the disease in livestock, with an increased number of cases reported in recent years. In the present work, the home range pattern of these bats was described through radio-telemetry monitoring. Based on the results obtained, allied with the available scientific knowledge, a transmission model was built incorporating geographic and behavioral determinants of the hematophagous bat in order to orientate and optimize the actions of epidemiological surveillance and control for the transmission of rabies. A bimodal network was constructed, composed by the integration between a network of contact between hematophagous bat roosts and a network of contact between these same roosts and farms of herbivores of economic interest. The resulting model showed greater significance of the network between roosts for the maintenance and transmission of the virus, besides the correlation between topography and spoliation. The model was able to identify farm communities at risk of rabies and in which roost communities the virus circulates. The understanding of the interactions between bats and their forage sources, influenced by the environment, allows to establish more precise surveillance and control measures and, ultimately, a lower cost-benefit ratio of these actions.

Keywords: Desmodus rotundus. Rabies. Telemetry. Network analysis. Epidemiological surveillance. 


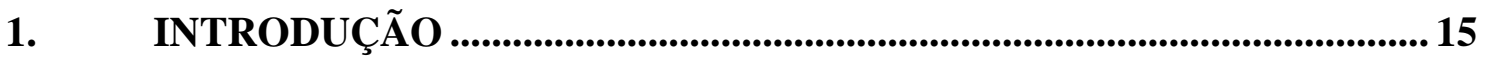

1.1. O Desmodus rotundus ..................................................................................... 15

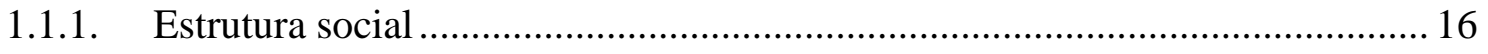

1.1.2. Seleção e uso de abrigos........................................................................... 18

1.1.3. Alimentação e hábitos de predação .................................................................. 19

1.1.4. Reprodução e desenvolvimento................................................................. 20

1.2. Desmodus rotundus e a raiva .......................................................................... 22

1.3. Controle da raiva em herbívoros domésticos................................................. 24

1.4. Sobre a dissertação .......................................................................................... 26

1.5. Objetivos....................................................................................................... 26

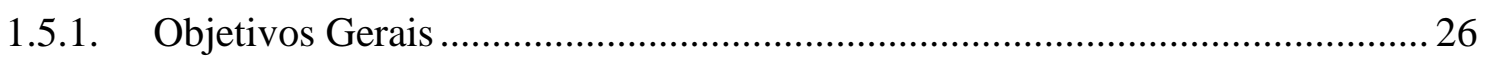

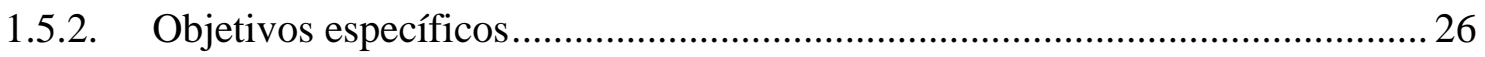

2. CAPÍTULO 1: USO DE MÉTODO DE TELEMETRIA PARA IDENTIFICAÇÃO DA ÁREA DE USO DE MORCEGOS DA ESPÉCIE Desmodus rotundus ................................................................................................... 27

2.1. Resumo ................................................................................................................ 28

2.2. Introdução ............................................................................................. 29

2.3. Materiais e métodos............................................................................................ 31

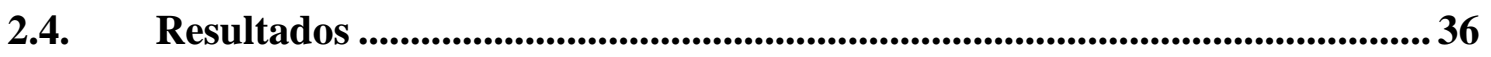

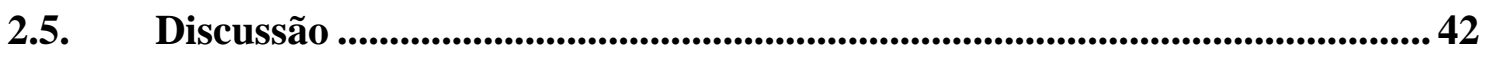



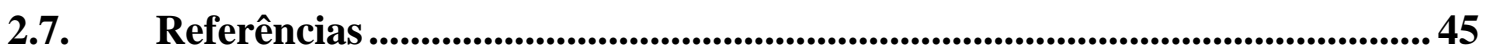

3. CAPÍTULO 2: CONSTRUÇÃo E ANÁLISE DE REDES DE CONTATO DE MORCEGOS DA ESPÉCIE Desmodus rotundus PARA A TRANSMISSÃO DO VÍRUS DA RAIVA EM AMBIENTES RURAIS ..50

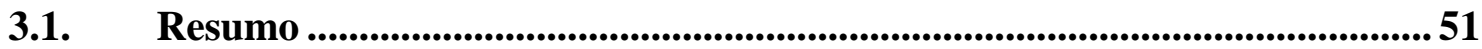

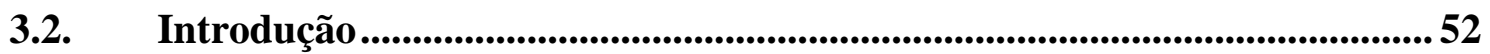

3.3. Materiais e métodos.............................................................................53

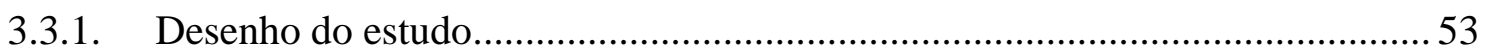

3.3.2. Metodologia para construção da rede entre abrigos e propriedades rurais ...... 54

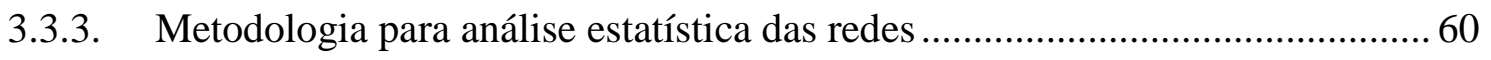

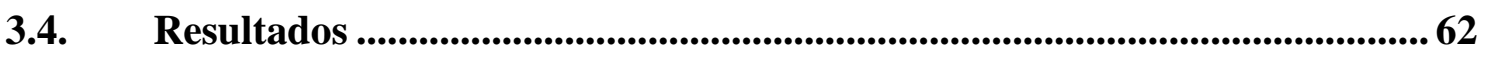




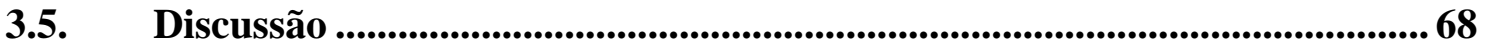

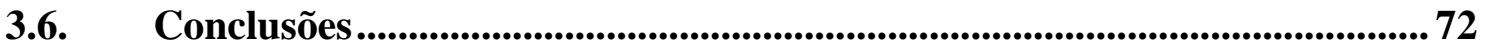

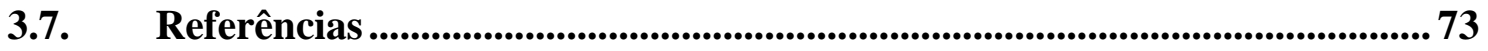

4. CONSIDERAÇÕES FINAIS................................................................. 77

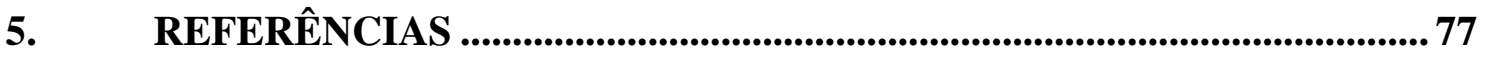




\section{INTRODUÇÃO}

\subsection{O Desmodus rotundus}

O Desmodus rotundus (Figura 1.1) é uma espécie de morcego pertencente à Ordem Chiroptera, Subordem Microchiroptera, Família Phyllostomidae e Subfamília Desmodontinae (NEUWEILER, 2000). Possui ampla distribuição na América Latina, desde o norte do México até o norte da Argentina, incluindo todo o território do Brasil (HAYES, 2018). É a espécie mais abundante dentre as três espécies hematófagas, sendo uma das espécies de morcegos mais estudadas no mundo, devido às perdas econômicas causadas pelo forrageio sanguíneo em herbívoros de interesse econômico e a transmissão da raiva para estes animais e para o homem (REIS et al., 2007).

Figura 1.1 - Imagem de um morcego Desmodus rotundus.

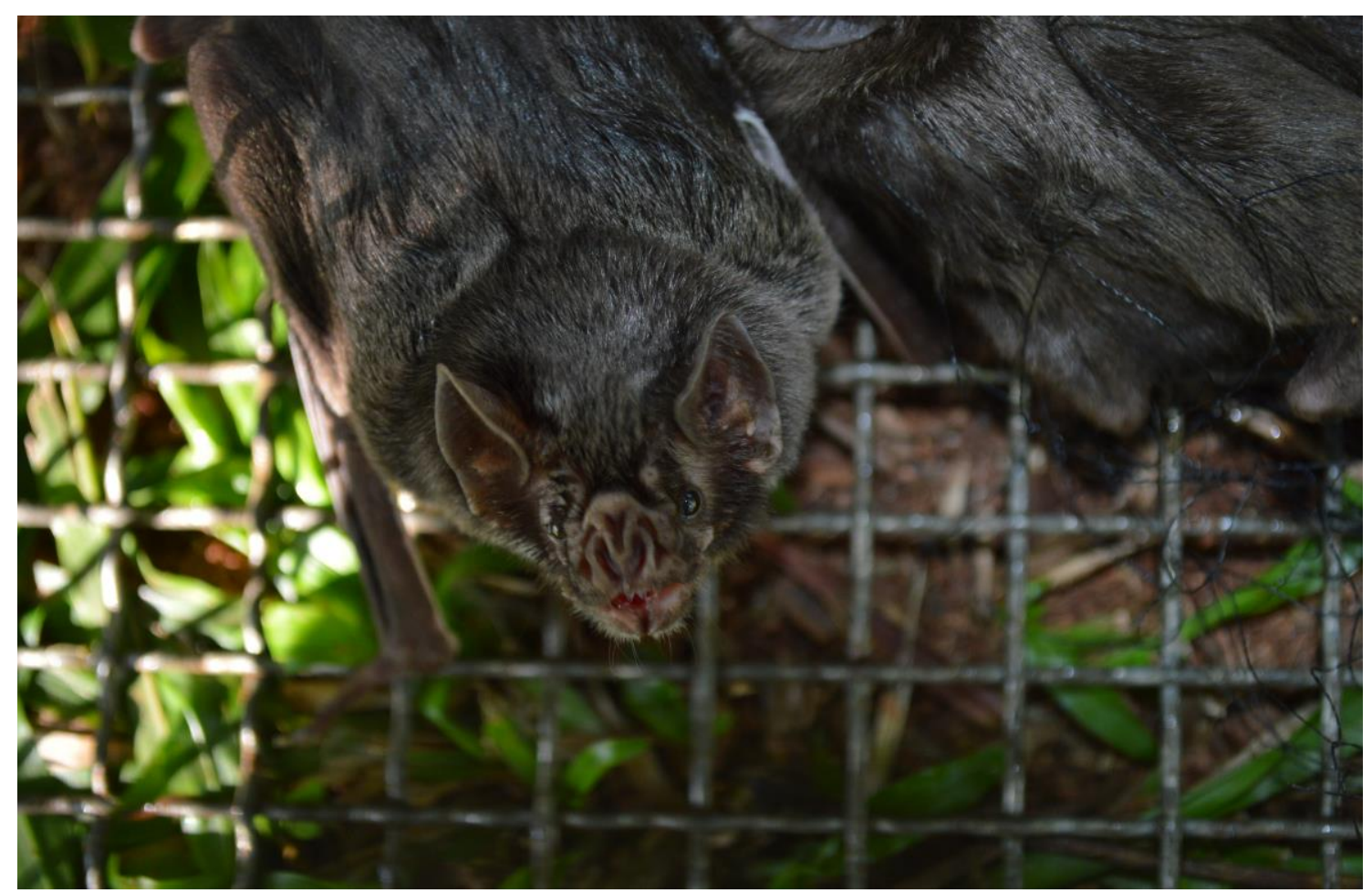

Fonte: DIAS, R. A. Lorena, Estado de São Paulo, Brasil, 2017.

Indivíduos adultos desta espécie têm envergadura de cerca de $35 \mathrm{~cm}$, pesando entre 25 e $40 \mathrm{~g}$, sendo considerados morcegos de médio porte. Sua pelagem é macia e de coloração cinza, avermelhada, dourada ou alaranjada (REIS et al., 2007). 
Agrupam-se em colônias pequenas, geralmente entre 10 a 50 indivíduos, porém colônias de mais de 100 indivíduos podem ser observadas, principalmente em áreas onde não é realizado controle populacional de morcegos (REIS et al., 2007). São animais noctívagos, com picos de atividade entre as 19 e 23 horas. No restante do tempo, ficam restritos a abrigos diurnos (REIS et al., 2007). Abrigam-se em áreas escuras e úmidas tais quais ocos de árvores, cavernas e estruturas artificiais e uma única colônia usualmente se distribui em diversos abrigos alternativos (GOMES; UIEDA, 2004; BREDT et al., 1998).

\subsubsection{Estrutura social}

Morcegos da espécie Desmodus rotundus vivem em bandos, ou comunidades, chamados de colônias em abrigos naturais (grutas, cavernas, oco de arvores) ou artificais (bueiros, casas e construções abandonadas). Os abrigos com o maior número de indivíduos são compostos primordialmente por fêmeas e alguns poucos machos adultos, além dos filhotes (GOMES; UIEDA, 2004; BREDT et al., 1998). São, portanto, abrigos reprodutivos, denominados abrigos maternidade. Isso não significa que animais que não estejam reproduzindo não habitem abrigos maternidades. A denominação abrigo maternidade é dado em referência aos abrigos de colônias que gerem filhotes, onde coabitem machos e fêmeas adultas (também denominado por harém, por haver alguns poucos machos e muitas fêmeas). Nas proximidades dos abrigos maternidade pode haver abrigos geralmente com um menor número de indivíduos, compostos exclusivamente por machos jovens que dispersaram destes abrigos maiores, após a puberdade, e geralmente expulsos pelos machos adultos dominantes. Os machos destes abrigos competem uns com os outros pelo acesso às fêmeas, repelindo machos de outros abrigos que porventura tentem copular com as fêmeas de seu harém. As fêmeas, por sua vez, podem copular não só com machos dominantes, mas também com machos de posição social mais baixa em dias subsequentes, inclusive com machos de outros abrigos (CRICHTON; KRUTZCH, 2000; NEUWEILER, 2000). 
Abrigos com fêmeas de $D$. rotundus são mais estáveis, com poucas novas fêmeas entrando no grupo, a cada dois anos. Ou seja, machos adultos trocam de grupo mais frequentemente que fêmeas. Devido ao comportamento dispersivo do macho, estes abrigos maiores consistem de machos adultos não aparentados e de fêmeas que são relacionadas através de diversas linhagens maternas. O movimento dispersivo de machos sugere que seja improvável que fêmeas em grupos sejam aparentadas através de paternidade comum. Dados genéticos indicam que o grau de parentesco entre membros de grupos de fêmeas seja de 0,2-0,3 (CRICHTON; KRUTZCH, 2000; NEUWEILER, 2000).

Supondo que numa colônia composta por uma dada população de morcegos D. rotundus eventualmente ocorram mortes de indivíduos, seja por causas naturais, predação, além de nascimentos de novos indivíduos e ainda movimentos dispersivos, tanto de entrada quanto de saída de indivíduos de/para outras colônias (BLACKWOOD et al., 2013). Este movimento dispersivo ocorre por diversas razões e é um comportamento natural entre morcegos desta espécie, podendo ser ocasionado por: (a) superpopulação de um abrigo estimulando indivíduos mais jovens à dispersarem para outro ou um novo abrigo (CARTER et al., 2018); (b) disputas entre machos pela dominância da colônia; (c) disponibilidade abrigos novos que apresentam melhores condições ambientais, estimulando deslocamentos migratórios de $D$. rotundus de outros abrigos e etc. (PIAGGIO et al., 2017). Sendo assim, mortes, nascimentos e deslocamentos migratórios de indivíduos fazem da população de morcegos $D$. rotundus uma população conceitualmente caracterizada e chamada por aberta (SILVIS et al., 2014).

Indivíduos de um mesmo abrigo estão frequentemente em contato físico e aqueles que retornam após um forrageio sanguíneo fracassado, tipicamente iniciam contato nasal-nasal com outros membros da colônia, facilitando a troca de informação olfatória (KUNZ; FENTON, 2003). Nestes casos, realizam troca recíproca de alimento (altruísmo), permitindo afirmar que estes animais possuem estrutura social bem desenvolvida e complexa (WILKINSON, 1985).

Para o $D$. rotundus, a reciprocidade é a base da comunidade, garantida pelo altruísmo. Membros do grupo voam sozinhos à noite para forrageio em suas vítimas, mas alimentam um ao outro quando retornam ao abrigo. Acredita-se que 
a limpeza (grooming) social sirva de meio para um indivíduo faminto determinar se o seu vizinho se alimentou (NEUWEILER, 2000).

\subsubsection{Seleção e uso de abrigos}

O D. rotundus é fiel a um abrigo por longos períodos (KUNZ; FENTON, 2003). Esta espécie de morcegos utiliza abrigos em cavidades, geralmente onde não ocorram modificações no ambiente, podendo, portanto, selecionar abrigos formados naturalmente ou artificialmente (GOMES; UIEDA, 2004; BREDT et al., 1998). Abrigos em cavidades são selecionados por morcegos para aumentar a proteção contra predadores e competidores, possibilitando um aumento de conservação de energia devida ao comportamento gregário de fêmeas e filhotes. A seleção do abrigo também pode ocorrer em decorrência de elementos da paisagem como proximidade da água e borda de fragmentos de mata e por proximidade com fontes de alimentação (KUNZ; FENTON, 2003).

Quando indivíduos mudam de abrigo, geralmente dirigem-se para um outro nas proximidades. Espécies tropicais e subtropicais são sedentárias e não migratórias, incluindo $\circ D$. rotundus. Apesar de não haver migração, muito comum em morcegos de áreas temperadas, pode haver dispersão, que é a movimentação em uma via, de um local para outro, geralmente (mas não sempre) para longe do local de nascimento. Machos jovens imaturos são mais propensos à dispersão que fêmeas jovens (KUNZ; FENTON, 2003).

Este comportamento é utilizado para conservação de energia, porém isto não se justificaria em trópicos. Supõe-se que nos trópicos, este comportamento se dê pela proximidade com fontes de alimento (CRICHTON; KRUTZCH, 2000).

Abrigos noturnos (digestórios) desempenham um papel importante na ecologia do forrageamento de morcegos, usados como locais de descanso entre ataques de forrageamento, permitindo a digestão e conservação de energia, retiro de predadores e clima inclemente, além de servir de local para interações sociais. Edifícios, pontes, cavernas, minas e superfícies rochosas podem servir para este fim. Estes abrigos são localizados nas proximidades das fontes de alimentação para reduzir o custo energético do retorno aos abrigos diurnos e minimizar o risco de predação. A distância da área de forrageamento e 
condições climáticas podem influenciar o momento que os indivíduos retornam ao abrigo diurno após o forrageamento (KUNZ; FENTON, 2003).

A relação dos abrigos com as áreas de forrageamento é influenciada pelo tipo de abrigo utilizado, a disponibilidade de abrigos, alimento e água, tamanho da colônia e o ciclo reprodutivo dos morcegos. Embora as áreas de uso possam ser grandes, os indivíduos frequentemente concentram sua atividade noturna em áreas localizadas, ao invés de forragear em toda a área. A distância máxima de deslocamento noturno para forrageamento é de $10 \mathrm{~km}$ (MEDINA et al., 2007). A proximidade com a fonte de alimento pode ser um importante determinante na seleção do local de abrigo. Os animais tendem a retornar para o mesmo abrigo, mesmo após a troca de áreas de forrageamento e, se abrigos disponíveis estiverem escassos, um maior deslocamento até uma fonte de alimento deve custar menos energeticamente que a busca por um novo abrigo próximo à área de forrageamento (KUNZ; FENTON, 2003).

\subsubsection{Alimentação e hábitos de predação}

O Desmodus rotundus é uma espécie estritamente hematófaga diferindo-se de todas as demais espécies de morcegos, por sua ecologia alimentar altamente especializada (KUNZ; FENTON, 2003). Estes morcegos não acumulam grandes reservas de gordura e não podem sobreviver mais de três dias sem se alimentar (FREITAS et al., 2013), sendo assim, estes reduzem o perigo da fome e morte por inanição através de um comportamento altruísta em resposta a um padrão de comportamento implorativo, desenvolvido por indivíduos que falharam no forrageio (KUNZ; FENTON, 2003). Os indivíduos que se alimentaram regurgitam parte da dieta não somente para seus filhotes, mas também para outros membros adultos da colônia (NEUWEILER, 2000).

Podem se deslocar por até $10 \mathrm{~km}$ em um único sentido para forragear (MEDINA et al., 2007), supostamente na dependência da combinação de audição passiva e dicas infravermelhas para a localização de uma presa dormindo, além do local apropriado na vítima para 0 ataque. A visão provavelmente desempenha um papel determinante na orientação, porém o $D$. rotundus também utiliza uma gama de outras dicas sensoriais (olfatórias, acústicas e infravermelhas) no forrageio (CAMPBELL et al., 2002). 
Para se aproximarem e morderem suas presas sem serem detectados, utilizam comportamentos de locomoção não usuais dentre os morcegos, movendo-se furtivamente no solo e escalando a presa rapidamente. Durante o forrageio noturno, o $D$. rotundus pousa perto ou diretamente na vítima, podendo correr ou saltar rapidamente, graças a adaptações anatômicas dos membros anteriores e principalmente posteriores, evitando reflexos defensivos da vítima.

O morcego localiza uma região altamente vascularizada, umidifica uma área com saliva, pressiona a sua mandíbula protuberante e seus dentes angulados aparentes para baixo e, em um ataque rápido, corta um pedaço de pele (NEUWEILER, 2000). A ferida, que alcança a derme, sangra continuamente por um tempo considerável, pois o morcego continuamente a estimula com sua língua áspera queratinizada, abrindo novos capilares. Além disso, a saliva contém substâncias que previnem a coagulação, fazendo com que ferida continue a sangrar, por atuação do ativador de plasminogênio, que previne a coagulação através de fibrinólise (NEUWEILER, 2000).

\subsubsection{Reprodução e desenvolvimento}

O sistema reprodutivo do $D$. rotundus pode ser considerado de grupos multimachos/multi-fêmeas ao longo do ano (CRICHTON; KRUTZCH, 2000). O D. rotundus tem os períodos mais extremos de gestação (205 dias) e lactação (10 meses) dentre todas as espécies de morcegos (KUNZ; FENTON, 2003). Um único filhote é gerado por gestação e gêmeos raramente são gerados (Figura 1.2). Para as espécies hematófagas, as mudanças de estação climática e disponibilidade de alimento podem ser determinantes do ciclo reprodutivo, como acontece para as demais espécies de morcegos (NEUWEILER, 2000). O D. rotundus apresenta um padrão reprodutivo classificado como poliestral multimodal contínuo, ou seja, a fêmea pode entrar no cio até quatro vezes por ano, com cio pós-parto e sincronia entre fêmeas, assim os filhotes nascem na mesma época, geralmente na época mais quente e chuvosa do ano (CRICHTON; KRUTZCH, 2000; REIS et al., 2007). Verão por exemplo no Estado de São Paulo ee todo o ano em regiões como Norte, Nordeste e Centro-Oeste do Brasil. 
A gestação custa à fêmea de $D$. rotundus surpreendentemente pouca energia. Os embriões de morcegos desenvolvem-se vagarosamente, se comparados a outros mamíferos. No segundo mês de vida, o filhote começa a receber alimento regurgitado pela mãe, sendo carregado por ela, inclusive durante o voo, até os cinco meses, quando então torna-se independente (REIS et al., 2007). D. rotundus é uma espécie longeva, chegando a 18 anos em vida livre, um período não excepcional entre os morcegos (KUNZ; FENTON, 2003).

Figura 1.2 - Filhote de Desmodus rotundus agarrado ao teto da mãe em abrigo no interior de cabana abandonada.

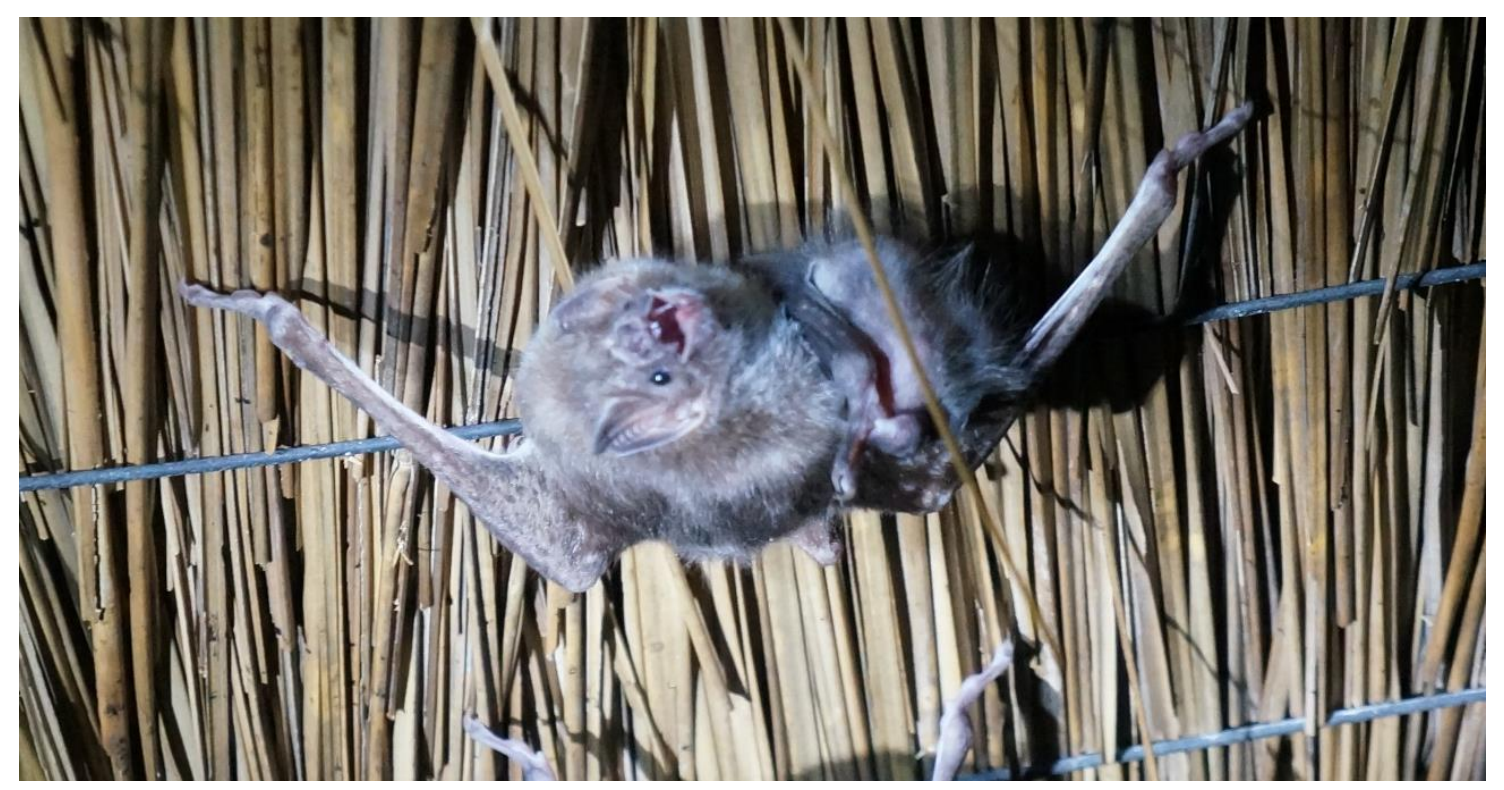

Fonte: POMPEI, J. C. Departamento de Rocha, Uruguai, 2016.

No nascimento, filhotes de morcego são proporcionalmente maiores que o de outros mamíferos, comparando-se períodos de gestação. Um filhote de $D$. rotundus pesa cerca de $7 \mathrm{~g}$ no nascimento, ou seja, cerca de 1/6 do peso de um animal adulto (CRICHTON; KRUTZCH, 2000). Os recém-nascidos possuem um bom controle neuromuscular, utilizado-o imediatamente logo no primeiro dia de vida para agarrar-se à pelagem da mãe ou ao teto do abrigo. A produção de leite e a troca de energia alcança o pico próximo ao desmame. As fêmeas prenhes se juntam no período diurno em abrigos maternidade para parir e cuidar dos filhotes. 
O primeiro vôo ocorre quando o filhote atinge $75 \pm 20 \%$ do peso vivo dos adultos, com 4-6 semanas de idade, sendo um evento de alto risco, pela inexperiência de técnicas de voo e orientação (KUNZ; FENTON, 2003). Os primeiros voos se dão ao redor do abrigo e, neste período crítico, a mãe os alimenta por regurgitação. Os machos não participam na criação dos filhotes (NEUWEILER, 2000). A maturidade sexual é atingida lentamente, entre um e dois anos (CRICHTON; KRUTZCH, 2000).

\subsection{Desmodus rotundus e a raiva}

O desflorestamento reduz a disponibilidade de abrigos naturais e a perda de habitat proporciona um enorme impacto na densidade e distribuição de quirópteros (KUNZ; FENTON, 2003), influenciando inclusive a transmissão de doenças para animais de produção e humanos. Além disso, a introdução de espécies invasoras, como javalis, pode aumentar a disponibilidade de presas para os morcegos hematófagos, aumentando sua densidade populacional e a probabilidade de contatos infecciosos (PEDROSA et al., 2015).

Morcegos possuem características-chave que contribuem para uma maior ocorrência de agentes transmissíveis que em outros grupos de mamíferos: voam, alguns são muito abundantes, amplamente distribuídos e muitos são altamente gregários. Por estas razões, o papel do morcego na evolução de patógenos, propagação e disseminação de agentes infecciosos é significativa. Algumas características adicionais da história de vida dos morcegos os tornam particularmente vulneráveis à carga de doenças infecciosas: longevidade, início tardio da maturidade sexual e baixa fecundidade para animais de seu porte (KUNZ; FENTON, 2003).

O interesse no estudo da ecologia de doenças infecciosas em populações de morcegos não se refere somente ao entendimento dos detalhes da maneira com que patógenos infecciosos são mantidos e como impactam em suas populações, mas também para questionar como os morcegos evoluíram novas estratégias para enfrentar doenças infecciosas. De fato, morcegos desempenham um papel proeminente como reservatórios de doenças infecciosas (KUNZ; FENTON, 2003). 
Atualmente, 25 famílias de vírus são conhecidas por infectar vertebrados, sendo 10 delas associadas a morcegos, a maioria vírus do tipo RNA (somente um vírus DNA, da família Herpesviridae, no Novo Mundo). A Ordem Mononegavirales (vírus de cadeia negativa e RNA segmentado) contém três famílias possivelmente associados ou bem documentada em morcegos: Filoviridae, Paramyxoviridae e Rhabdoviridae. Ao menos um vírus de cada família pode ser classificado como agente emergente letal para humanos e outros animais. Exemplos: vírus Marburg e Ebola (Filoviridae); Hendra, Menengle e Nipah (Paramyxoviridae) e raiva (Rhabdoviridae) (KUNZ; FENTON, 2003).

Historicamente, desde 1911 (CARINI, 1911), o vírus da raiva foi considerado o agente etiológico em todos os casos de encefalite viral em que: (A) Inoculação em animais de laboratório com material cerebral de um caso tenha produzido encefalite por raiva; (B) Corpúsculo de Negri (inclusões eosinofílicas intracitoplasmática) tenham sido encontrados em esfregaços de material cerebral ou; (C) Anticorpos marcados com fluorescência para nucleoproteína (proteína N) viral tenha sido detectado em inclusões intracitoplasmáticas em neurônios infectados.

No final dos anos 1970, entretanto, vírus relacionados à raiva, porém distintos, foram identificados. O gênero Lyssavirus (lyssa, do grego, raiva) foi criado para envolver vírus que produzem encefalite raivosa em camundongos e reativos a anticorpos para proteína $\mathrm{N}$ do vírus da raiva, mas que pudessem ser diferenciados por reduzida reatividade cruzada no teste de neutralização viral com anticorpos para a glicoproteína $G$ do vírus e, em alguns casos, por uma falha vacinal. A identificação definitiva das espécies virais do gênero Lyssavirus é baseada na análise de sequências de nucleotídeos (KUNZ; FENTON, 2003).

Em 1967, em estudos observacionais, a prevalência de anticorpos anti-vírus rábico em morcegos sadios ou assintomáticos não excedeu $1 \%$, mas em moribundos, foi de 55\% (CONSTANTINE, 1967; CONSTANTINE et al., 1968). Com estes resultados, formulou-se a hipótese de imunidade adquirida e que indivíduos imunodeficientes mantinham o vírus nas populações coloniais. Além disso, foi sugerido que morcegos desenvolvessem infecções latentes e que se recuperavam da raiva (KUNZ; FENTON, 2003). 
Se houver imunidade adquirida à raiva, sugere-se que haja um mecanismo alternativo para a manutenção do vírus em uma população sem diminuições cíclicas da população, embora isto tenha sido considerado improvável em diversos trabalhos sobre manutenção do vírus em populações de vida livre. Se houvessem altas prevalências de anticorpos neutralizantes, poderia-se explicar porque mortalidades relacionadas à raiva não são observadas frequentemente (KUNZ; FENTON, 2003).

Faltam dados sobre latência, ou seja, o estado em que o ácido nucléico está presente na célula, mas transcrição e tradução são reprimidas a baixos níveis, além do período de incubação estendido do vírus da raiva em morcegos. Porém, existem hipóteses sobre a dormência deste vírus em tecido adiposo marrom e do estresse como reativador do vírus, pelo aumento da produção de cortisol. Sobre as rotas alternativas para a transmissão do vírus da raiva, também faltam dados sobre o papel de aerossóis e da urina, porém, sugere-se que recémnascidos tornem-se infectados através de mordedura ou lambedura logo após o nascimento, mas não antes. Mesmo que alguns estudos tenham sugerido infecções transplacentárias, a frequência é desconhecida.

Do ponto de vista da ecologia da doença, a transmissão vertical não é um mecanismo importante na manutenção enzoótica da raiva. Não há estudo que comprove a eliminação a longo termo do vírus da raiva por morcegos. Devido ao fato de o vírus da raiva ter sido encontrado em glândulas salivares e saliva de Desmodus rotundus somente em estados terminais de infecção e após a replicação cerebral, conclui-se que o $D$. rotundus sobreviva longos períodos sem ser afetado clinicamente por infecção por raiva no sistema nervoso central.

\subsection{Controle da raiva em herbívoros domésticos}

O Programa Nacional de Controle da Raiva dos Herbívoros (PNCRH) teve suas normas técnicas aprovadas pela Instrução Normativa 5 de 01 de março de 2002 (BRASIL, 2002). O Manual Técnico do PNCRH foi aprovado pela Portaria SDA 168 de 27 de setembro de 2005 (BRASIL, 2005). O PNCRH tem como objetivo a redução da prevalência da raiva nas populações de herbívoros de interesse econômico através da vacinação de herbívoros em situações 
específicas, estratégias de controle de transmissores, vigilância epidemiológica e educação em saúde, com responsabilidades compartilhadas entre o Ministério da Agricultura, Pecuária e Abastecimento (MAPA), os serviços veterinários oficiais e laboratórios credenciados.

A raiva é uma doença de notificação compulsória, ou seja, proprietários devem informar ao serviço veterinário oficial suspeitas de doenças nervosas em herbívoros, espoliação (mordedura) por morcegos hematófagos e a existência de abrigos desses animais em suas propriedades rurais. O serviço veterinário, por sua vez, deve prestar atendimento imediato à suspeita, coletando material, realizando controle da população de morcegos hematófagos, se necessário, e educação sobre a vacinação contra a raiva. A vacina, quando preconizada, deve conter vírus inativado, em dose de $2 \mathrm{ml}$, aplicada por via intra-muscular ou subcutânea. Sua indicação é compulsória quando da ocorrência de focos em bovinos e equídeos com idade superior a 3 meses, em um raio de $12 \mathrm{~km}$ a partir do foco primário.

O cadastro e monitoramento de abrigos de Desmodus rotundus é realizado pelos serviços veterinários oficiais, que realizam esta atividade, principalmente durante a atuação nos focos, sendo a busca ativa por abrigos realizada principalmente nos Estados de São Paulo e Espírito Santo. Os abrigos são georeferenciados e eventualmente são realizadas capturas de Desmodus rotundus, com tratamento dos animais com pasta vampiricida e envio de espécimes para diagnóstico de raiva (MAPA, 2009). 


\subsection{Sobre a dissertação}

Esta dissertação está dividida em dois capítulos. O capítulo 1, "Uso de método de telemetria para identificação de padrões comportamentais de morcegos da espécie Desmodus rotundus", trata sobre o trabalho de campo desenvolvido para determinar os padrões de uso de fontes de alimentação pelos morcegos, utilizando rádio-telemetria. Os achados do capítulo 1 forneceram premissas para as análises desenvolvidas no capítulo 2, “Construção e análise de redes de contato de morcegos da espécie Desmodus rotundus para transmissão da raiva em ambientes rurais", que trata sobre 0 desenvolvimento de modelo de transmissão da raiva entre morcegos hematófagos e herbívoros de interesse econômico.

\subsection{Objetivos}

\subsubsection{Objetivos Gerais}

Desenvolvimento de um modelo de transmissão da raiva entre morcegos da espécie Desmodus rotundus e herbívoros de interesse econômico a fim de aperfeiçoar as ações de vigilância e controle da raiva.

\subsubsection{Objetivos específicos}

- Identificação de padrões de uso de fontes de alimentação pelo Desmodus rotundus (Capítulo 1);

- Construção de um modelo de redes de contato entre abrigos de Desmodus rotundus e propriedades rurais baseado em determinantes comportamentais e geográficos identificados previamente (Capítulo 2). 
2. CAPÍTULO 1: USO DE MÉTODO DE TELEMETRIA PARA IDENTIFICAÇÃO DA ÁREA DE USO DE MORCEGOS DA ESPÉCIE 


\subsection{Resumo}

O papel desempenhado pelos morcegos Desmodus rotundus é determinante para a manutenção e transmissão do vírus da raiva ao homem e aos herbívoros de interesse econômico, impactando a saúde pública e a produção agropecuária. A importância do $D$. rotundus reside não só na capacidade de transmitir o vírus da raiva, mas também na sua capacidade de se adaptar às mudanças ecológicas provocadas pelo homem, concedendo-lhes uma ampla distribuição geográfica. O desmatamento, a intensificação da pecuária e a antropização reduziram o número de presas silvestres, oferecendo em troca uma nova e abundante fonte de abrigo e alimento para o morcego vampiro. Uma melhor compreensão dos aspectos biológicos, dos hábitos predatórios e da interação estre essa espécie de morcegos com o meio ambiente que os cerca resultaria no aprimoramento da metodologia de controle seletivo, visando a redução dos impactos da doença. Sendo assim, este trabalho propoem estudo descritivo utilizando método de acompanhamento das atividades diárias de morcegos desta espécie no município de Guaratinguetá, Estado de São Paulo, Brasil. O uso de método de telemetria identificou padrões de área de uso que poderiam tornar mais precisos os serviços veterinários oficiais dos programas de controle da raiva. Os resultados demonstram que a topografia do terreno e a distância entre abrigos e propriedades rurais são também determinantes para a seleção de presas de gado em áreas rurais.

Palavras-chave: Desmodus rotundus. Raiva. Telemetria. Ecologia. Topografia. 


\subsection{Introdução}

A raiva é uma enfermidade aguda do sistema nervoso, progressiva, causada por um vírus RNA da família Rhabdoviridae, do gênero Lyssavirus. Todas as espécies de mamíferos são suscetíveis à enfermidade, transmitida principalmente através da mordedura de animais infectados, via saliva (WHO, 2013). O papel desempenhado pelos morcegos da espécie Desmodus rotundus é determinante para a manutenção e transmissão do vírus da raiva para 0 homem e para herbívoros de interesse econômico (REIS et al., 2007), causando prejuízos à saúde pública e à produção agropecuária. No Brasil, durante o período de 2012 a 2016, foram realizados 18.858 atendimentos pós-exposição para raiva por acidentes ou ataques envolvendo morcegos (SEMINÁRIO DE VIGILÂNCIA E CONTROLE DA RAIVA NO ESTADO DE SÃO PAULO, 2017). Já as perdas econômicas no setor agropecuário causadas pelo vírus, estima-se que, durante o período de 1993 a 2002, chegam a US $\$ 50$ milhões na América Latina (BELOTTO et al., 2005).

O D. rotundus é uma espécie de morcego pertencente à Ordem Chiroptera, Subordem Microchiroptera, Família Phyllostomidae e Subfamília Desmodontinae (NEUWEILER, 2000) cuja fonte de alimentação é o sangue de aves e mamíferos domésticos ou selvagens (GREENHALL, 1988). Formam colônias que podem variar de 20 a mais de 100 indivíduos (UIEDA, 1987) e abrigam-se ocos de árvores, edificações, pontes, cavernas, minas e superfícies rochosa como abrigos diurnos para realização de digestão e conservação de energia, como retiro contra predadores e clima inclemente, além de servir de local para interações sociais (BREDT et al., 1998).

Indivíduos de um mesmo abrigo estão frequentemente em contato físico e aqueles que retornam após o forrageio sanguíneo tipicamente iniciam contato nasal-nasal com os membros, facilitando a troca de informação olfatória. Além disso, realizam troca recíproca de alimento, comportamento denominado de altruísmo recíproco, quando um indivíduo regurgita uma fração da sua ingesta para outro. Este hábito de lambedura entre os indivíduos garante não somente o acesso a alimento aos indivíduos que não se alimentaram durante o repasto noturno, mas também a coesão social da colônia (WILKINSON et al., 2016). O hábito de limpeza do corpo por outro indivíduo da colônia, chamado de 
"grooming social" é observado nos $D$. rotundus com uma frequência 14 vezes maior que em outras espécies de morcegos, sendo considerada uma característica adaptativa ligada ao altruísmo recíproco e à coesão social (CARTER; LEFFER, 2015). Por estes motivos, pode-se afirmar que a estrutura social desta espécie é bem desenvolvida e complexa (KUNZ; FENTON, 2003).

A importância do $D$. rotundus não reside unicamente na capacidade de transmitir a enfermidade, mas também em sua capacidade de adaptação às mudanças ecológicas provocadas pelo homem, garantindo-lhes ampla distribuição geográfica - desde o norte do México até o Uruguai (HAYES; PIAGGIO, 2018). Durante o período Pré-Colombiano das Américas, o morcego vampiro forrageava em presas silvestres em meio às florestas tropicais. Porém o desmatamento, a intensificação da pecuária e edificações diminuíram a oferta de animais silvestres, oferecendo por sua vez aos morcegos-vampiros uma nova e abundante fonte de abrigo e alimentação (BELWOOD; MORTON, 2014).

A expansão da população de $D$. rotundus está ligada a maior facilidade ou acessibilidade detes morcegos por herbívoros de interesse econômico em comparação a mamíferos nativos. Estes animais domésticos são constantemente atacados durante a noite em áreas próximas aos abrigos destes morcegos (VOIGT; KELM, 2006; MIALHE, 2014), provavelmente porque os herbívoros de interesse econômico são uma fonte de alimentação mais previsível que animais silvestres de vida livre. Esta alteração de presa selvagem para uma presa doméstica e introduzida caracteriza uma adaptação evolutiva dos morcegos hematófagos que determinou, em última instância, a transmissão do vírus da raiva aos animais domésticos.

Por conta destes fatos, o programa de controle da raiva em herbívoros domésticos é baseado no controle seletivo da população dos transmissores ( $D$. rotundus) pelo serviço oficial de defesa agropecuária (MAPA, 2009). Este programa contempla uma série de ações de vigilância, prevenção e resposta à focos de raiva, incluindo ações como a identificação de novos abrigos e revisitação de abrigos conhecidos de morcegos $D$. rotundus que estejam atacando e transmitindo raiva para rebanhos de animais e pessoas, captura e administração de pasta com warfarina (fármaco anti-coagulante) no dorso dos morcegos, para que, durante o grooming social, outros indivíduos da colônia ingiram a pasta e sejam intoxicados pelo fármaco (MAPA, 2009). Este método 
poderia causar a morte indiscriminada de indivíduos das colônias, podendo desestruturá-las, aumentando as chances de disputas por abrigos e fêmeas e, em última instância, a probabilidade de contatos infecciosos entre os morcegos (CONDORI-CONDORI et al., 2018).

O melhor entendimento sobre os aspectos biológicos, os comportamentos sociais e os hábitos de predação desta espécie de morcegos resultariam no aperfeiçoamento de metodologias já empregadas de controle seletivo populacional, com vistas à diminuição de impactos causados pela enfermidade. Parâmetros tais como escolha de rebanhos a serem predados, tempo de forrageamento, escolha de abrigos e rotina de vida de morcegos da espécie $D$. rotundus auxiliariam programas de controle da raiva em herbívoros domésticos, otimizando o emprego de recursos e a eficácia da metodologia. O objetivo deste trabalho é identificar padrões de comportamento que poderiam elucidar ou acrescentar hipóteses para auxiliar os serviços oficiais na execução dos programas de controle da raiva.

\subsection{Materiais e métodos}

O presente trabalho trata-se de um estudo descritivo, portanto, foram realizadas campanhas de trabalho à campo com o objetivo de acumular informação sobre abrigos diurnos de $D$. rotundus, informações biométricas, determinação dos sexos dos indivíduos capturados, monitoramento da circulação do vírus da raiva, agressões a herbívoros em propriedades rurais e determinação da rede entre os abrigos utilizados pelos $D$. rotundus e as propriedades rurais criadoras de herbívoros de interesse econômico.

O município de Guaratinguetá, no Estado de São Paulo, foi selecionado como área de estudo, em decorrência da disponibilidade de informações pregressas sobre ocorrência da raiva em herbívoros, de mordeduras de morcegos em herbívoros e monitoramentos de abrigos de $D$. rotundus. Ressalta-se que esta área é extremamente antropizada, podendo-se considerar, como únicas fontes de alimentação disponíveis aos $D$. rotundus, os herbívoros domésticos.

Inicialmente, realizou-se uma campanha-piloto durante o período de 19 a 22 de setembro de 2016 a fim de testar os equipamentos e a metodologia 
empregada. Posteriormente, foram realizadas cinco campanhas para obtenção dos dados:

- $1^{\text {a }}$ campanha: de 09 a 20 de janeiro de 2017;

- 2ampanha: de 24 a 28 de abril de 2017 ;

- 3 ${ }^{\mathrm{a}}$ campanha: de 24 a 28 de julho de 2017;

- 4⿳亠丷厂 campanha: de 25 a 29 de setembro de 2017;

- 5a campanha: no dia 07 de fevereiro de 2018.

Os abrigos de $D$. rotundus a serem monitorados foram determinados a partir do cadastro da Coordenadoria de Defesa Agropecuária (CDA) e completados pela equipe de trabalho, durante visitas a campo. Foram denominados abrigos ativos aqueles em que havia a presença de $D$. rotundus. Nestes, foram realizados esforços de captura diurna (caso fosse possível percorrer toda a sua extensão e fechar suas saídas, como bueiros) ou captura noturna (caso não fosse possível adentrá-los ou determinar todas as suas saídas). A equipe era formada por, ao menos três pesquisadores. Para as capturas diurnas, a equipe adentrou o abrigo equipada com puçá e gaiola para contenção dos $D$. rotundus com o intuito de capturar o maior número de indivíduos possível daquela colônia, se possível todos. Morcegos de espécies não hematófagos não foram alvo de captura. Em capturas noturnas, preconizou-se esforço com 4 horas de duração (das 20 às 00 horas), utilizando redes de neblina tipo ATX (KUNZ et al., 2009).

Independentemente do tipo de captura realizada, os seguintes parâmetros foram obtidos para cada $D$. rotundus capturado:

- Sexo: observação dos órgãos genitais (para fêmeas, também foram observados sinais de prenhez ou lactação);

- Faixa etária: observação da consolidação das epífises-diáfises da articulação metacarpo-falangeal através da transluminescência, com o uso de uma lanterna (KUNZ et al., 2009);

- Medidas biométricas: medição da envergadura e antebraço direito, com o auxílio de uma fita métrica e paquimetro, respectivamente;

- Peso: medido com o auxílio de uma balança portátil de $100 \mathrm{~g}$.

Estas informações foram anotadas em uma ficha individual. Uma amostra de saliva foi coletada em cada animal capturado, com um swab (KUNZ et al., 2009) (Figura 2.1). Estas amostras foram congeladas até serem levadas ao Laboratório 
de Zoonoses Virais da FMVZ-USP, para diagnóstico molecular do vírus da raiva.

O seguinte protocolo foi utilizado para conservação das amostras:

- Realização de esfregaço na cavidade oral com suabe esterilizado, utilizandose um por morcego, liberado o animal após a coleta;

- Corte da haste do suabe e colocação da extremidade utilizada para o esfregaço em tubo tipo Eppendorf (1 tubo/suabe);

- Conservação sob-refrigeração a $4^{\circ} \mathrm{C}$ para seu posterior encaminhamento ao laboratório.

Figura 2.1 - Procedimento de coleta de amostra de saliva de um morcego Desmodus rotundus.

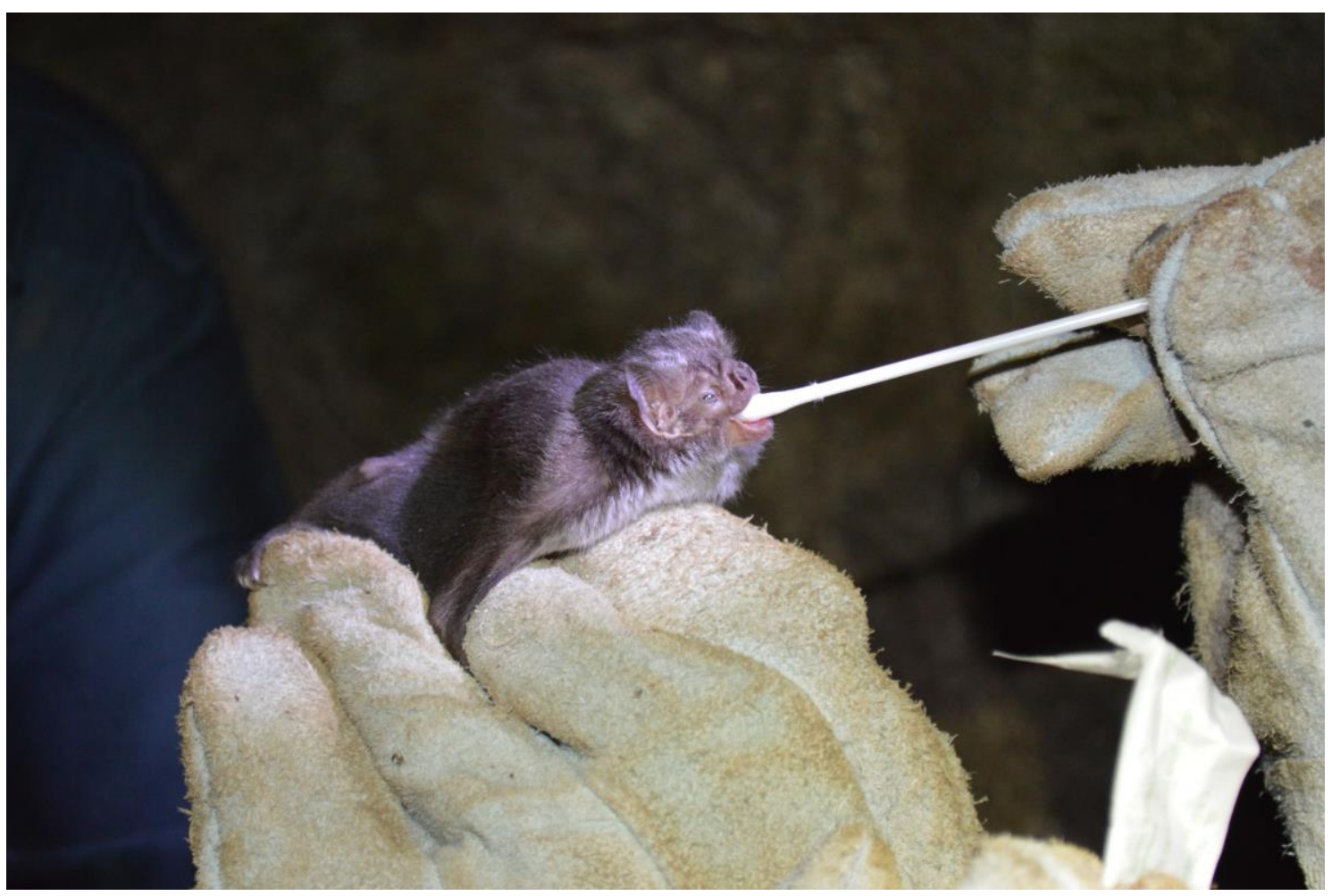

Fonte: DIAS, R. A. Lorena, Estado de São Paulo, Brasil, 2017.

As amostras de saliva foram entregues ao Laboratório de Virologia do Departamento de Medicina Veterinária Preventiva e Saúde Animal da Faculdade de Medicina Veterinária e Zootecnia da Universidade de São Paulo, que foram testadas para raiva por meio da transcriptase reversa PCR, RT-PCR (MACEDO et al., 2006).

Cada animal capturado recebeu uma anilha metálica numerada no antebraço direito, com coloração específica para cada abrigo. A marcação com anilha era feita a cada campanha nos animais não marcados, sendo as recapturas 
anotadas também na ficha individual. Para estimar a abundância e a dinâmica populacional da população de indivíduos que compõem os abrigos, foi utilizado o modelo de cálculo de populações de Cormack-Jolly-Seber para populações abertas (POLLOCK; ALPIZAR-JARA, 2005). Para tal, os dados foram calculados utilizando-se o software R com o pacote "RMark" (R, 2017; PACKAGE RMAK, 2017). Foram gerados modelos considerando-se as diferentes covariáveis (sexo, peso, faixa etária), tendo sido escolhido o modelo com a maior qualidade de ajuste através do Critério de Informação de Akaike (AIC).

Em cada abrigo, ao menos cinco morcegos capturados tiveram um rádiotransmissor miniaturizado (VHF) (Figura 2.2A). A seleção dos morcegos que seriam utilizados para receberem os rádios se deu por sexo e peso, ou seja, femeas e os machos de maior peso. Estes rádios pesavam $\sim 1 \mathrm{~g}$, com comprimento de $11 \mathrm{~mm}$, largura de $5 \mathrm{~mm}$ e $3 \mathrm{~mm}$ de altura, fixados na região dorsal com cola instantânea (AMELON et al., 2009) (Figura 2.3). As baterias destes rádio-transmissores possuíam vida útil de 60 dias, transmitindo um sinal a cada cinco minutos. Dispunha-se de 50 rádio-transmissores para 0 monitoramento telemétrico. Os sinais emitidos pelos rádios foram captados por receptores VHF (Figura 2.2B) instalados nas propriedades rurais monitoradas da região de estudo. O receptor possuía uma antena para captação de sinal e um processador capaz de armazenar informações dos sinais emitidos pelos transmissores de rádio instalados nos morcegos. Segundo o fabricante (Axabixo®) e após testes com os rádio-transmissores, os sinais emitidos poderiam ser captados a até $100 \mathrm{~m}$ de distância.

Os receptores foram instalados junto aos currais de pernoite dos rebanhos e em possíveis locais de passagem dos $D$. rotundus, como por exemplo, bordas de mata e rios. Além das propriedades, os abrigos de origem dos morcegos capturados também recebiam um receptor. Os receptores eram verificados diariamente quanto às baterias e as informações registradas. Dispunha-se de 10 receptores de sinal VHF, que eram utilizados nas propriedades rurais e abrigos, de forma escalonada por até três noites consecutivas, de modo a cobrir um raio de até $5 \mathrm{~km}$ ao redor de cada abrigo ativo (LORD, 1993). Os dados de telemetria foram usados na produção de mapas temáticos, utilizando-se o programa de computador QGIS 2.18.7 (QGIS, 2017). 
Figura 2.2 - Equipamentos de telemetria utilizados durante a pesquisa: (A) rádio-transmissores miniaturizados e $(B)$ receptores.

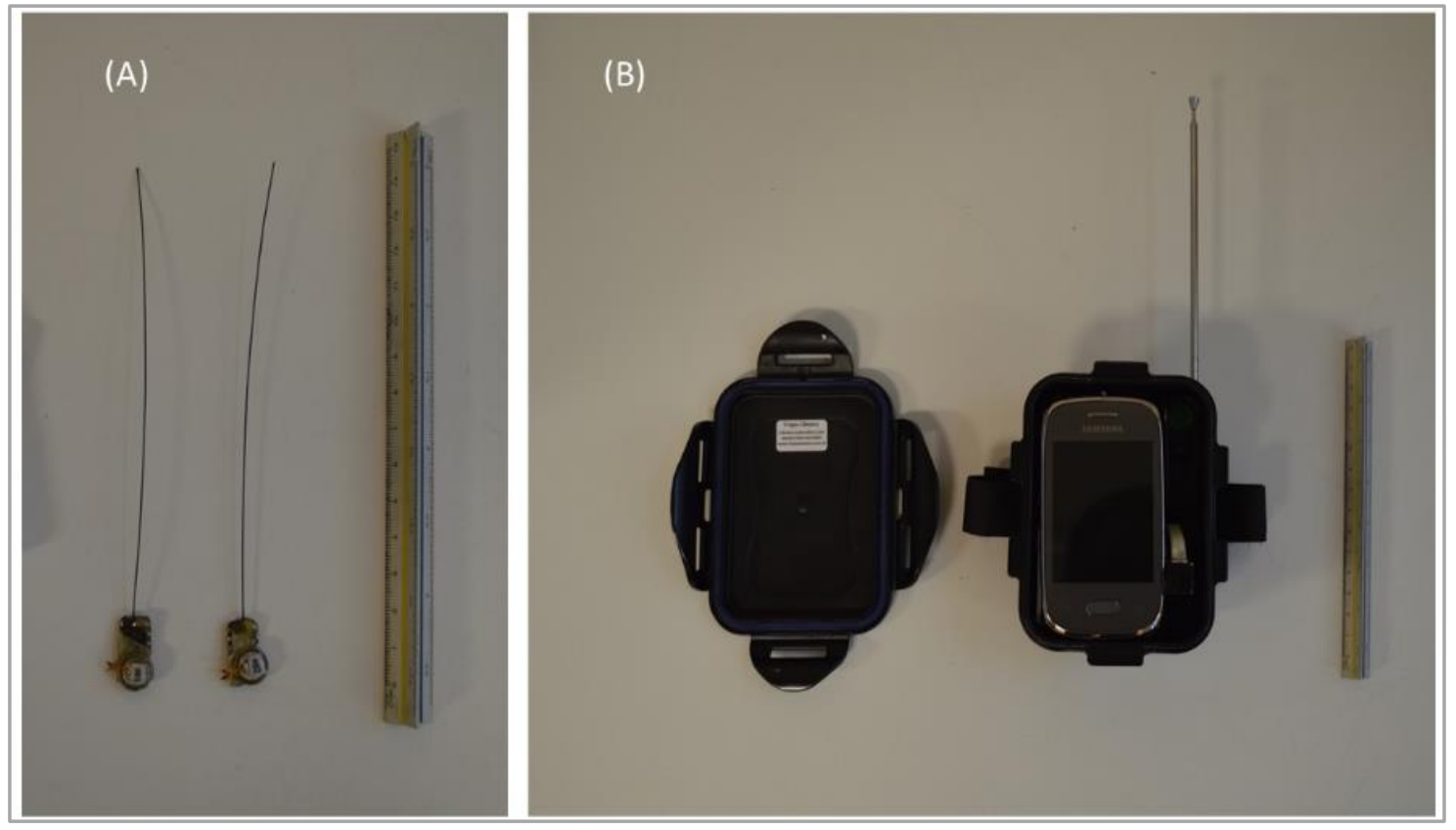

Observação: A régua de referência tem $15 \mathrm{~cm}$.

Figura 2.3 - Fixação do rádio-transmissor no dorso de um morcego Desmodus rotuntus.

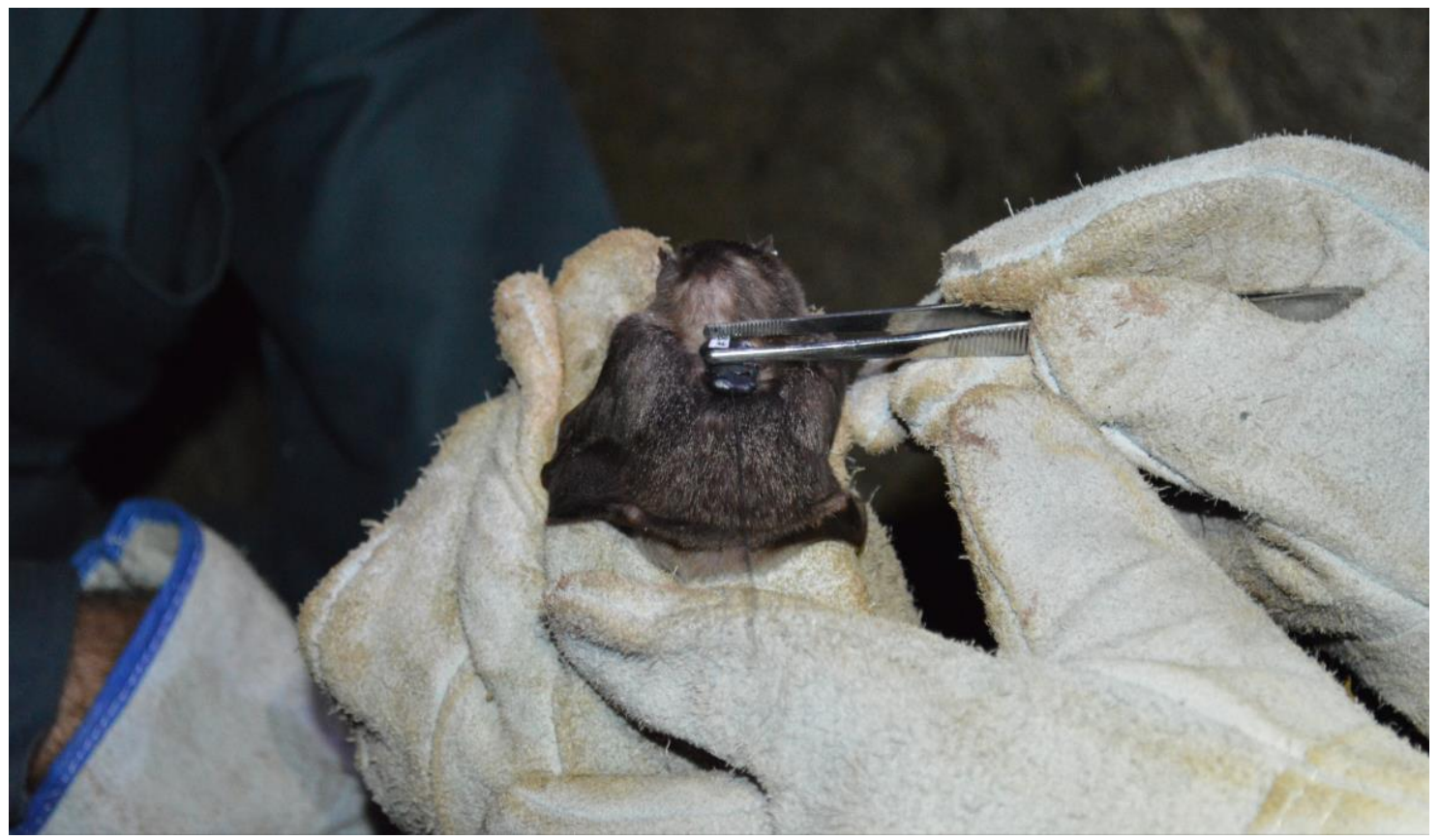

Fonte: DIAS, R. A. Lorena, Estado de São Paulo, Brasil, 2017.

As propriedades rurais foram selecionadas com base no cadastro da CDA e completados pela equipe de trabalho, durante visitas a campo. As propriedades rurais foram visitadas no início do projeto, ocasião em que os proprietários foram sensibilizados sobre o estudo de registro da frequência de espoliação 
(mordedura) de herbívoros de interesse econômico (bovinos, bubalinos, equídeos, ovinos, caprinos e suínos). Para o registro destas informações (número de animais espoliados e frequência por animal) foram registrados por meio de uma ficha contendo questões e tabelas para completude dos proprietários ao identificar agressões e/ou animais com sintomas neurológicos compatíveis com a raiva.

\subsection{Resultados}

A região de estudo compreendeu uma área de $200 \mathrm{~km}^{2}$ (Figura 2.4). Durante o período de estudo, foram visitados sistematicamente 37 propriedades rurais e 11 abrigos na área de estudo, a cada campanha de campo. Um dos abrigos não havia sido cadastrado pela CDA, tendo sido descoberto pela equipe de campo com o auxílio dos proprietários rurais da região. As informações gerais sobre as atividades e dados coletados durante as campanhas podem ser visualizadas na Tabela 2.1.

Tabela 2.1 - Número de propriedades rurais visitadas, número de receptores, abrigos de morcegos $D$. rotundus cadastrados pela CDA, número de rádios-transmissores instalados nos morcegos e o total de sinais registrados, por campanha.

\begin{tabular}{ccccccc}
\hline Campanha & $\begin{array}{c}\text { Proprieda } \\
\text { des rurais } \\
\text { visitadas }\end{array}$ & $\begin{array}{c}\text { Receptores } \\
\text { VHF }\end{array}$ & $\begin{array}{c}\text { Abrigos } \\
\text { monitorados }\end{array}$ & $\begin{array}{c}\text { D. rotundus } \\
\text { capturados }\end{array}$ & $\begin{array}{c}\text { Radio- } \\
\text { transmissores } \\
\text { instalados }\end{array}$ & $\begin{array}{c}\text { Total de sinais } \\
\text { registrados nos } \\
\text { receptores }\end{array}$ \\
\hline $\mathbf{1}$ & 16 & 07 & 11 & 07 & 05 & 02 \\
$\mathbf{2}$ & 15 & 08 & 09 & 22 & 13 & 106 \\
$\mathbf{3}$ & 32 & 06 & 09 & 15 & 10 & 246 \\
$\mathbf{4}$ & 26 & 07 & 07 & 15 & 14 & 14 \\
$\mathbf{5}$ & - & - & 03 & 19 & - & -
\end{tabular}

Observação: (-) Representa atividade não executada durante a campanha.

Dentre os abrigos visitados, foram identificados dois abrigos (Abrigos $\mathrm{A}$ e $\mathrm{B}$ ) com presença constante de morcegos $D$. rotundus. Todas as amostras submetidas ao laboratório, para diagnóstico da raiva, resultaram negativas. Os sinais de rádios capturados pelas antenas nas propriedades rurais foram todos oriundos de morcegos destes dois abrigos citados (Figura 2.2). 
Figura 2.4 - Mapa da área de estudo, com a localização dos abrigos visitados e as propriedades rurais onde radios receptors de sinal VHF foram instalados.
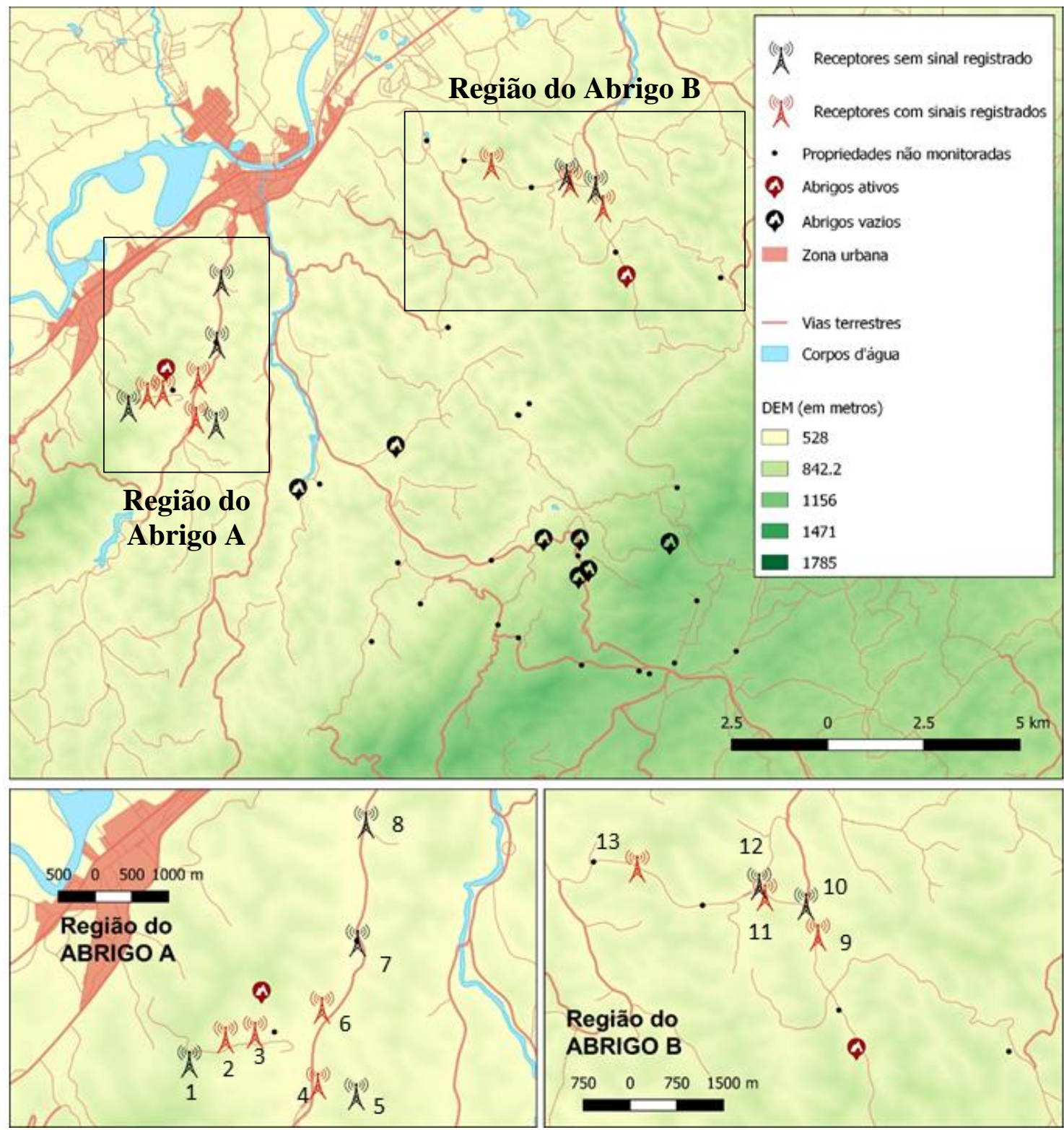

Observação: "Receptores sem sinal registrados" as propriedades rurais monitoradas com receptor de rádio VHF que não registraram sinais; "Receptores com sinais registrados" as propriedades rurais monitoradas com receptor de rádio VHF que registraram sinais; "Propriedades não monitoradas" propriedades rurais que não foram instalados receptores de rádio VHF.

O Abrigo A (Região A) tratava-se de uma gruta localizada no interior de um remanescente florestal de uma pequena propriedade rural. Durante as campanhas, foram capturados neste abrigo $01,19,15,15$ e 13 morcegos sucessivamente. Na $1^{\text {a }}$ campanha, a captura foi realizada em fonte de alimentação (redes armadas ao redor de um piquete contendo cinco bezerros 
bovinos constantemente agredidos), na qual apenas um $D$. rotundus foi capturado. A partir da $2^{\mathrm{a}}$ Campanha, as capturas passaram a ser realizadas diretamente no abrigo (gruta). A rede de neblina era instalada na primeira câmara da gruta, em "L", uma vez que era difícil o acesso às porções mais internas desta.

O Abrigo B (Região B) tratava-se de um bueiro para escoamento de água de uma represa. Neste caso, como era possível ter total acesso ao abrigo e fechar as saídas do bueiro antes do início do trabalho, os animais foram capturados durante o dia, pela manhã, utilizando-se de puçás. Durante as $1^{\underline{a}}, 2^{\underline{a}}$ e $5^{\underline{a}}$ Campanhas, foram capturados neste abrigo, sucessivamente, 05, 03 e 06 morcegos $D$. rotundus. Nas $3^{\mathrm{a}}$ e $4^{\mathrm{a}}$ Campanhas, nenhum morcego desta espécie foi observado, porém tendo sido observados morcegos de outras espécies. Para este abrigo, pode-se considerar que os números de $D$. rotundus contados constituem o censo populacional.

O Abrigo C trata-se de dois fornos de carvão abandonados dentro de uma propriedade rural de eucaliptos. Apenas durante a $2^{\mathrm{a}}$ campanha capturamos um indivíduo da espécie $D$. rotundus (sendo que haviam dois no total), em todas as demais campanhas não identificamos mais morcegos da espécie procurada habitando tal abrigo. Entretanto, morcegos de outras espécies foram identificados abrigando-se no recinto. Sendo assim, o abrigo em questão não será utilizado para as inferências e discussões apresentadas neste trabalho.

Conforme apresentado na Tabela 2.1, o Abrigo A foi o abrigo com ocupação constante e maior abundância de morcegos $D$. rotundus. Entretanto, o acesso às câmeras mais profundas da gruta era difícil, impossibilitando a visualização e estimação da população de $D$. rotundus que ali se abrigavam.

Utilizando-se das quantidades de indivíduos capturados e recapturados em cada campanha, identificamos sexo como provável medida variável para sobrevida e detecção (Figura 2.5).

Em ambos os casos, encontramos constância nos valores, sendo assim, aplicamos sobrevida e detecção como processos constantes. Os resultados para o modelo de Jolly-Seber apontam abundância total estimada para a colônia de 119 indivíduos durante a $2^{\mathrm{a}}$ captura, 149 indivíduos para a $3^{\mathrm{a}}$ captura e 129 indivíduos para a $4^{\mathrm{a}}$ captura. Os intervalos de confiança apontaram abundância mínima de 89 e máxima de 156 indivíduos para a $2^{\text {a }}$ captura, mínima de 94 e 
máxima de 182 indivíduos para a 3aㅡ captura e mínima de 84 e máxima de 184 indivíduos para a $4^{\text {a }}$ captura (Figura 2.3). OS cálculos e resultados foram realizados e obtidos através do uso do pacote RMark $(R, 2017)$ para o software estatístico R [PACKAGE RMARK, 2017].

Figura 2.5 - Gráfico da estimativa populacional para o Abrigo A.

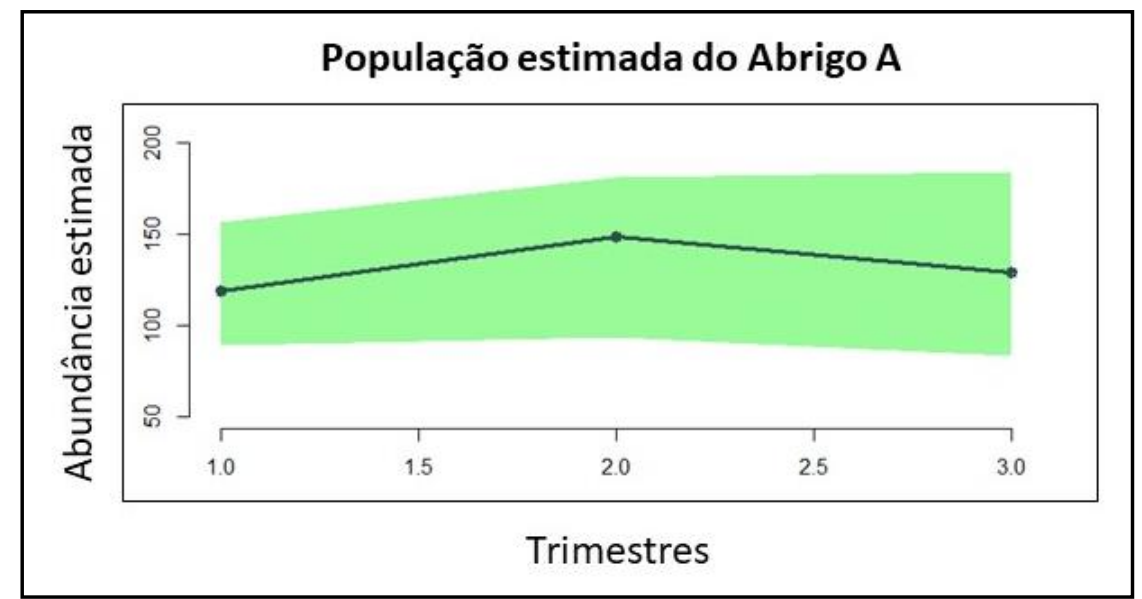

Os receptores de sinais de rádios foram instalados em propriedades rurais com herbívoros domésticos até $5 \mathrm{~km}$ de distância destes abrigos, sendo instalados próximos de locais onde os animais passavam a noite ou, de acordo com depoimentos de proprietários, nos locais onde os animais eram agredidos. As propriedades rurais que tiveram receptores de sinal de rádio foram destacadas com números (Tabela 2.2), formando dois agrupamentos no entorno dos abrigos ativos: Receptores de 01 a 08 compõem a área do Abrigo $A$, enquanto que os Receptores 09 a 13 compõem a área do Abrigo B. Sinais de rádio associados aos morcegos do Abrigo $\mathrm{A}$ foram registrados pelos Receptores 02, 0304 e 06. Um único receptor era instalado em cada propriedade rural, com exceção dos Receptores 04 e 05, que foram instaladas em uma mesma propriedade rural, porém em locais diferentes. Os Receptores 09, 11 e 13 registraram sinais referentes à rádio-transmissores instalados nos morcegos capturados no Abrigo B. Os Receptores 01, 05, 07, 08, 10 e 12 não registraram sinais de passagem dos rádio-transmissores.

$\mathrm{Na}$ Tabela 2.2, pode-se observar todos os morcegos que tiveram rádiotransmissores instalados. Além dos morcegos apresentados na Tabela 2.2 foram capturados outros $D$. rotundus, que por sua vez foram anilhados, pesados, 
aferidos parâmetros biométricos e em seguida soltos, sem a instalação do rádiotransmissor. Analisando a Figura 2.2 e a Tabela 2.2, é possível identificar qual morcego gerou o registro captado por um determinado receptor.

Nota-se que os morcegos que emitiram os sinais que foram captados pelos Receptores 11 e 13, instalados em duas propriedades rurais distintas não serão visualizados na Tabela 2.2. Isso se deve ao fato de que os sinais de rádio sofreram alteração e interferência, afetando o registro nas antenas, portanto, não foi possível identificar com exatidão qual morcego teve passagem registrada, apenas que algum dos animais com rádio-transmissor passou pelo local. Sendo assim, mesmo não sabendo qual deles emitiu o sinal registrado nos Receptores 11 e 13, sabemos que um dos animais marcados com o rádio-transmissor gerou sinal captado pelos receptores, e que este(s) veio (vieram) do Abrigo B.

Tabela 2.2 - Relação dos registros de rádios-transmissores instalados em morcegos Desmodus rotundus na área de estudo.

(continua)

\begin{tabular}{|c|c|c|c|c|c|c|c|}
\hline $\begin{array}{l}\text { Anilha de } \\
\text { metal }\end{array}$ & $\begin{array}{l}\text { Local de } \\
\text { captura }\end{array}$ & $\begin{array}{c}\text { Data de } \\
\text { captura } \\
\text { (dd/mm/aa) }\end{array}$ & $\begin{array}{c}\text { Radio } \\
\text { instalado }\end{array}$ & $\begin{array}{l}\text { Total de } \\
\text { registros }\end{array}$ & $\begin{array}{l}\text { Receptor do } \\
\text { registro }\end{array}$ & $\begin{array}{l}\text { Data de } \\
\text { registro } \\
\text { (dd/mm/aa) }\end{array}$ & $\begin{array}{l}\text { Horário de } \\
\text { registro }\end{array}$ \\
\hline Vermelho 01 & Abrigo B & $10 / 01 / 17$ & \# 04 & 01 & 09 & $11 / 01 / 17$ & $03: 54 h$ \\
\hline Vermelho 02 & Abrigo B & $10 / 01 / 17$ & \# 21 & & & $\ldots$ & \\
\hline Vermelho 03 & Abrigo B & $10 / 01 / 17$ & \# 23 & & & $\ldots$ & \\
\hline Vermelho 04 & Abrigo B & $10 / 01 / 17$ & \# 24 & & & $\ldots$ & \\
\hline Vermelho 05 & Abrigo B & $10 / 01 / 17$ & \# 25 & & & $\ldots$ & \\
\hline Vermelho 06 & Abrigo B & $24 / 04 / 17$ & \# 37 & & & $\ldots$ & \\
\hline Vermelho 07 & Abrigo B & $24 / 04 / 17$ & \# 27 & 02 & 09 & $25 / 04 / 17$ & $22: 00 h$ às $22: 06 \mathrm{~h}$ \\
\hline Vermelho 08 & Abrigo B & $24 / 04 / 17$ & \# 34 & & & $\ldots$ & \\
\hline Amarelo 02 & Abrigo A & $25 / 04 / 17$ & \# 36 & 01 & 03 & $27 / 04 / 17$ & $22: 22 \mathrm{~h}$ \\
\hline Amarelo 04 & Abrigo A & $25 / 04 / 17$ & \# 44 & 97 & 03 & $26 / 04 / 17$ & $01: 19 \mathrm{~h}$ às $04: 47 \mathrm{~h}$ \\
\hline Amarelo 09 & Abrigo A & $25 / 04 / 17$ & \# 43 & & & $\ldots$ & \\
\hline Amarelo 10 & Abrigo A & $25 / 04 / 17$ & \# 40 & 01 & 03 & $26 / 04 / 17$ & 03:53h \\
\hline Amarelo 13 & Abrigo A & $25 / 04 / 17$ & \# 26 & & & $\ldots$ & \\
\hline Amarelo 14 & Abrigo A & $25 / 04 / 17$ & \# 06 & & & $\ldots$ & \\
\hline Amarelo 15 & Abrigo A & $25 / 04 / 17$ & \# 39 & & & $\ldots$ & \\
\hline Amarelo 16 & Abrigo A & $25 / 04 / 17$ & \# 31 & & & $\ldots$ & \\
\hline Amarelo 17 & Abrigo A & $25 / 04 / 17$ & \# 08 & & & $\ldots$ & \\
\hline Amarelo 18 & Abrigo A & $25 / 04 / 17$ & \# 33 & & & $\ldots$ & \\
\hline Laranja 02 & Abrigo A & $25 / 07 / 17$ & \# 42 & & & $\ldots$ & \\
\hline
\end{tabular}


(conclusão)

\begin{tabular}{|c|c|c|c|c|c|c|c|}
\hline $\begin{array}{c}\text { Anilha de } \\
\text { metal }\end{array}$ & $\begin{array}{l}\text { Local de } \\
\text { captura }\end{array}$ & $\begin{array}{c}\text { Data de } \\
\text { captura } \\
\text { (dd/mm/aa) }\end{array}$ & $\begin{array}{c}\text { Radio } \\
\text { instalado }\end{array}$ & $\begin{array}{l}\text { Total de } \\
\text { registros }\end{array}$ & $\begin{array}{l}\text { Receptor do } \\
\text { registro }\end{array}$ & $\begin{array}{c}\text { Data de } \\
\text { registro } \\
\text { (dd/mm/aa) }\end{array}$ & $\begin{array}{l}\text { Horário de } \\
\text { registro }\end{array}$ \\
\hline Laranja 03 & Abrigo A & $25 / 07 / 17$ & \# 47 & $\ldots$ & & & \\
\hline Laranja 04 & Abrigo A & $25 / 07 / 17$ & \# 48 & 52 & 06 & $26 / 07 / 17$ & $02: 01 \mathrm{~h}$ às $05: 21 \mathrm{~h}$ \\
\hline Laranja 06 & Abrigo A & $25 / 07 / 17$ & $\# 49$ & 01 & 04 & $27 / 07 / 17$ & $23: 36 h$ \\
\hline \multirow[b]{2}{*}{ Laranja 07} & & & & 02 & 06 & $27 / 07 / 17$ & $23: 18 \mathrm{~h}$ às $23: 20 \mathrm{~h}$ \\
\hline & Abrigo A & 25/07/17 & \# 50 & 09 & 06 & $28 / 07 / 17$ & $04: 46 h$ às $04: 56 h$ \\
\hline \multirow[t]{4}{*}{ Laranja 08} & Abrigo A & $25 / 07 / 17$ & \# 35 & 01 & 06 & $26 / 07 / 17$ & $02: 41 \mathrm{~h}$ \\
\hline & & & & 01 & 06 & $26 / 07 / 17$ & 04:01h \\
\hline & & & & 118 & 03 & $26-27 / 07 / 17$ & $23: 00 h$ às $04: 29 h$ \\
\hline & & & & 15 & 06 & $26 / 07 / 17$ & $20: 40 h$ às $22: 14 \mathrm{~h}$ \\
\hline \multirow[t]{2}{*}{ Laranja 11} & Abrigo A & $25 / 07 / 17$ & $\# 17$ & 01 & 06 & $26 / 07 / 17$ & $00: 48 \mathrm{~h}$ \\
\hline & & & & 12 & 06 & $27 / 07 / 17$ & $19: 41 \mathrm{~h}$ às $20: 24 \mathrm{~h}$ \\
\hline Laranja 12 & Abrigo A & $25 / 07 / 17$ & \# 16 & $\cdots$ & & & \\
\hline Laranja 13 & Abrigo A & $25 / 07 / 17$ & \# 29 & $\ldots$ & & & \\
\hline \multirow[t]{2}{*}{ Laranja 14} & Abrigo A & $26 / 09 / 17$ & \# 19 & $\ldots$ & & & \\
\hline & & & & 01 & 04 & $27 / 09 / 17$ & $00: 58 \mathrm{~h}$ \\
\hline \multirow[t]{2}{*}{ Laranja 15} & Abrigo A & $26 / 09 / 17$ & \# 15 & 01 & 04 & $27 / 09 / 17$ & 05:07h \\
\hline & & & & 01 & 04 & $28 / 09 / 17$ & $01: 53 h$ \\
\hline Laranja 16 & Abrigo A & $26 / 09 / 17$ & \# 09 & 01 & 04 & $27 / 09 / 17$ & 01:10h \\
\hline Laranja 17 & Abrigo A & $26 / 09 / 17$ & \# 20 & 01 & 04 & $27 / 09 / 17$ & $02: 04 \mathrm{~h}$ \\
\hline Laranja 18 & Abrigo A & $26 / 09 / 17$ & \# 41 & & & $\ldots$ & \\
\hline \multirow[t]{2}{*}{ Laranja 19} & Abrigo A & $26 / 09 / 17$ & \# 07 & & & $\cdots$ & \\
\hline & & & & 01 & 04 & $27 / 09 / 17$ & $02: 02 \mathrm{~h}$ \\
\hline \multirow{3}{*}{ Laranja 20} & & & & 01 & 04 & $28 / 09 / 17$ & $02: 12 h$ \\
\hline & Abrigo A & 26/09/17 & \# 02 & 01 & 04 & $28 / 09 / 17$ & $04: 25 h$ \\
\hline & & & & 01 & 02 & $28 / 09 / 17$ & $02: 13 \mathrm{~h}$ \\
\hline Verde 01 & Abrigo A & $26 / 09 / 17$ & \# 12 & & & $\ldots$ & \\
\hline \multirow{2}{*}{ Amarelo 02} & & & & 01 & 04 & $27 / 09 / 17$ & $02: 56 h$ \\
\hline & Abrigo A & 26/09/17 & \# 14 & 02 & 04 & $27 / 09 / 17$ & $03: 17 \mathrm{~h}$ às $03: 21 \mathrm{~h}$ \\
\hline Amarelo 03 & Abrigo A & $26 / 09 / 17$ & \# 18 & 01 & 04 & $27 / 09 / 17$ & $01: 26 \mathrm{~h}$ \\
\hline Amarelo 16 & Abrigo A & $26 / 09 / 17$ & \# 11 & & & $\ldots$ & \\
\hline Laranja 03 & Abrigo A & $26 / 09 / 17$ & \# 10 & 01 & 04 & $27 / 09 / 17$ & 03:07h \\
\hline Laranja 07 & Abrigo A & $26 / 09 / 17$ & $\# 46$ & & & $\ldots$ & \\
\hline Laranja 11 & Abrigo A & $26 / 09 / 17$ & \# 38 & & & $\ldots$ & \\
\hline
\end{tabular}




\subsection{Discussão}

O processo para obtenção dos registros dos rádio-transmissores pelos receptores dependeu da captura dos $D$. rotundus e instalação dos rádiotransmissores no dorso dos animais, mas, além disso, da instalação apropriada dos receptores de sinal VHF nas propriedades rurais em locais que maximizassem a probabilidade de obtenção de sinais emitidos pelos rádiotransmissores. Considerando-se o raio de $100 \mathrm{~m}$ para detecção do sinal VHF emitido por um rádio-transmissor por um receptor instalado em uma fonte de alimentação (área de deteç̧ão), a velocidade de deslocamento em voo do $D$. rotundus de $13 \mathrm{~km} / \mathrm{h}$, a baixa altura de voo, a cerca de $1 \mathrm{~m}$ do solo (PIAGGIO et al., 2017) e a frequência de emissão do sinal VHF pelo rádio-transmissor de 5 min, a probabilidade de captação do sinal emitido por um rádio transmissor seria de, no máximo, $20 \%$, tendendo a $0 \%$ conforme a rota de voo tangenciasse a área de detecção do receptor. Além disso, considerando-se que no máximo 10 receptores foram instalados simultaneamente ao redor de cada abrigo, somando uma área sob monitoramento telemétrico de $31,42 \mathrm{~km}^{2}$ e que a distância Euclidiana máxima para repasto noturno do $D$. rotundus é de $10 \mathrm{~km}$ (LORD, 1993; MEDINA et al., 2007; MAPA, 2009), a área de forrageamento seria de $31.415,93 \mathrm{~km}^{2}$. Desta forma, a área sob monitoramento seria de, no máximo, $0,001 \%$. Pode-se inferir, baseando-se nestas aproximações, que a probabilidade de detecção dos sinais dos rádio-transmissores instalados nos morcegos seria muito baixa.

As limitações na recepção do sinal de rádio deveram-se em grande parte pelo próprio rádio-transmissor. Deve-se lembrar que um $D$. rotundus adulto pesa até $45 \mathrm{~g}$, e pode consumir até um terço de seu peso vivo em sangue (NEUWEILER, 2000), sendo o voo seu principal meio de locomoção. O rádio-transmissor deveria ser leve o bastante para não interferir no voo do morcego, porém que tivesse potência para a emissão de sinais em um período razoável de tempo, aliado ao tamanho da bateria utilizada. A frequência da emissão do sinal de rádio pelo transmissor, estipulada junto ao fabricante em $5 \mathrm{~min}$, antes do início das campanhas de campo, deu-se por que antes da realização do projeto-piloto, planejava-se capturar os morcegos nas fontes de alimentação e instalar os 
receptores nos abrigos, o que se mostrou inviável, pelas limitações logísticas no campo. Mesmo com tais limitações, foi possível monitorar, em dois dos três abrigos onde foram observados $D$. rotundus, todas as propriedades rurais criadoras de herbívoros em uma distância Euclidiana de $5 \mathrm{~km}$ a partir de cada abrigo. Em ambos os casos, tanto os registros de mordeduras por morcegos nos herbívoros, quanto de sinais de VHF captados pelos receptores foram obtidos a uma distância menor, ou seja, concentraram-se próximos aos abrigos.

Ressalta-se que, diferentes dos morcegos do Abrigo A, que foram capturas com uso de rede de neblina na área externa ao abrigo, os morcegos do Abrigo B foram capturados por meio de puças no interior do abrigo, o que provalmente causou algum tipo de estresse nos morcegos que os fizeram abandonar temporariamente 0 abrigo. Esta seria a razão para não ter sido identificado nenhum morcego desta espécie no Abrigo B durante as Campanhas 3 e 4.

Observou-se uma possível relação entre a altitude do abrigo e a altitude dos rebanhos predados, além da distância. Dois receptores (01 e 05), situados a sudoeste e sudeste do Abrigo A, mesmo que mais próximos (considerando a distância Euclidiana) do abrigo e possuindo grandes rebanhos (com relação aos rebanhos das imediações do Abrigo A), estavam localizados a altitudes maiores que as do abrigo. Todos as propriedades rurais onde houve registro de rádio no receptor, estavam situados a altitudes inferiores à do abrigo. Na propriedade rural onde foi instalado o Receptor 01, mesmo não tendo registrados sinais de nenhum rádio-transmissor, o proprietário alegou que alguns animais foram constantemente mordidos por morcegos, porém estes animais são mantidos em um curral próximo do Abrigo $A$, à mesma altitude deste. Com relação ao Receptor 05, que foi instalado atrás de uma elevação do terreno em uma pastagem onde os bovinos pernoitavam, o proprietário relatou que nesta área não havia mordeduras por morcegos, ocorrendo somente em uma área mais próxima ao Abrigo A, onde foi instalado o Receptor 04. Este receptor registrou sinais de rádio-transmissores, corroborando a hipótese de provável relação entre a topografia e a localização dos rebanhos de herbívoros predados. Desta forma, a área de maior risco para ocorrência de mordeduras estaria à distâncias mais próximas e em altitudes inferiores às do abrigo.

$O D$. rotundus precisa alimentar-se em intervalos menores que três dias, caso contrário poderia morrer por inanição (NEUWEILER, 2000). Sendo assim, no 
início da noite, quando despertando, estão famintos e precisam alimentar-se. Havendo fontes de alimentação a altitudes inferiores, os morcegos utilizariam assim a própria gravidade como forma de alcançarem presas o mais rápido possível com menor gasto energético. O que não aconteceria caso tivesse que atacar animais em localidades topográficas superiores, pois teriam de utilizar as poucas reservas de energia disponível para suplantar a gravidade para alcançar suas presas. Portanto, deve haver uma impedância tal na busca por fontes de alimentação a altitudes superiores à do abrigo, que somente seria enfrentada pelos morcegos famintos caso não houvessem fontes de alimentação abaixo ou se a competição com co-específicos fosse elevada.

Apesar do $D$. rotundus poder ingerir até metade de seu peso vivo durante um repasto sanguíneo (NEUWEILER, 2000), seria possível inferir que o animal gastaria ainda mais energia tendo de vencer a gravidade de volta ao abrigo com tamanho peso extra para alçar voo. Entretanto, após o repasto, os morcegos podem, antes de voltar aos seus abrigos de origem, parar nos chamados "abrigos digestórios" (BREDT et al., 1998). Este abrigo têm a função de servir como ponto de descanso para os morcegos hematófagos, onde podem absorver os nutrientes e a água do sangue ingerido, necessária para manter sua homeostase e excretar grande parte da água e do ferro não utilizados. Vale lembrar que os morcegos tendem a ser sedentários, voltando aos seus abrigos de origem, e que a absorção dos nutrientes e água se dá em cerca de meia hora (NEUWEILER, 2000). Então, descansado, tendo excretado grandes volumes de água e ferro dispensáveis, o $D$. rotundus retornaria para o abrigo mais leve e com mais energia, contra a gravidade. Este comportamento poderia se caracterizar como uma das mais conhecidas e simples leis que regem a natureza, a lei do mínimo esforço (SHADMEHR; HUANG; AHMED, 2016).

\subsection{Conclusões}

O uso do método de telemetria para o serviço oficial, utilizando os equipamentos disponíveis hoje, não trariam benefícios ao sistema de vigilância de morcegos hematófagos para controle da raiva. Os custos inerentes aos equipamentos e com recursos humanos necessários para colher informações 
úteis não valeria o esforço. Entretanto, para questões de estudo da biologia desta espécie de morcegos, a telemetria trouxe achados relevantes.

Ficou evidente a relação entre topografia com a escolha das propriedades rurais a serem agredidas, além de evidenciar questões comportamentais sobre a tentativa de se evitar disputas, havendo rotação para predação, sem que haja animais de uma mesma colônia predando simultaneamente uma mesma fonte de alimentação. Os resultados deste trabalho indicam a realização de um estudo para verificar a correlação que existiria entre topografia e comportamento de predação.

\subsection{Referências}

AMELON S. K.; DALTON D. C.; MILLSPAUGH J. J.; WOLF S. A. Radiotelemetry. Kunz H., Parsons S. (eds.), 2009. Ecological and behavioral methods for the study of bats, 2 ed., Johns Hopkins University Press, Baltimore, Maryland.

BELOTTO A.; LEANES L. F.; SCHNEIDER M. C.; TAMAYO H.; CORREA E. Overview of rabies in the Americas. Virus Research, v. 111, n. 4, p. 5-12, 2005.

BELWOOD, J. J.; MORTON, P.A. Vampires: The real story. Viruses, v. 6, p. 1911-1928, 2014.

BLACKWOOD J. C., STREICKER D. G., ALTIZER S., ROHANI P. Resolving the roles of immunity, pathogenesis, and immigration for rabies persistence in vampire bats. Proc. Natl. Acad. Sci. U S A, v. 110 (51), p. 20837-20842, 2013.

BREDT A., ARAUJO F. A., CAETANO J. R. J., RODRIGUES M. G. R., YOSHIKAWA M., SILVA M. M. S. Morcegos em áreas urbanas e rurais: Manual de manejo e controle. Brasilia: Ministerio da Saude, Fundação Nacional de Saude, p. 72, 1998. 
CARTER G. G.; LOGSDON R.; ARNOLD B. D.; MENCHACA A.; MEDELLIN R. A. Adult Vampire Bats Produce Contact Calls When Isolated: Acoustic Variation by Species, Population, Colony, and Individual. PloS ONE, 2012.

CARTER G.; LEFFER L. Social grooming in bats: are vampire bats exceptional? PloS ONE, 2015.

CARTER G. G., FORSS S., PAGE R. A., RATCLIFFE J. M. Younger vampire bats (Desmodus rotundus) are more likely than adults to explore novel objectives. PloS ONE, 13(5), 2018.

CONDORI-CONDORI R. E., STREICKER D. G., CABEZAS-SANCHEZ C., VELASCO-VILLA A. Enzootic and epizootic rabies associated with vampire bats, Peru. Emerging Infectious Diseases, v. 24, n. 5, 2018.

Controle da raiva dos herbívoros. Ministério da Agricultura, Pecuária e Abastecimento, Secretaria de Defesa Agropecuária. Manual Técnico, Brasília, Distrito Federal, 2009.

GREENHALL A. M. Feeding behavior. In: Greenhall A. M., Schmidt U. (eds) Natural history of vampire bats. CRC Press. Florida, p. 111-131, 1988.

HAYES M. A., PIAGGIO A. J. Assessing the potential impacts of a changing climate on the distribution of a rabies virus vector. PloS ONE. 2018.

KUNZ T. H., FENTON M. B. Bat ecology. The University of Chicago Press. Chicago, 2003.

KUNZ T. H.; HODGKISON R.; WEISE C. D. Methods of capturing and handling bats. Kunz H., Parsons S. (eds.), 2009. Ecological and behavioral methods for the study of bats, 2 ed., Johns Hopkins University Press, Baltimore, Maryland.

LORD, R. D. A taste for blood: The highly specialized vampire bat will dine on nothing else. Wildlife Conservation, v. 96, p. 32-38, 1993. 
MACEDO, C. I.; CARNIELI JR., P.; BRANDÃO, P. E.; ROSA, E. S. T.; OLIVEIRA, R. N.; CASTILHO, J. G.; MEDEIROS, R.; MACHADO, R. R.; OLIVEIRA, R. C.; CARRIERI, M. L.; KOTAIT, I. Diagnosis of human rabies cases by polymerase chain reaction of neck-skin samples. The Brazilian Journal of Infectious Diseases, v. 10, n. 5, p. 341-345, 2006.

MEDINA A. M., HARVEY C. A., MERLO D. S., VÍLCHEZ S., HERNÁNDEZ B. Bat Diversity and Movement in an Agricultural Landscape in Matiguas, Nicaragua. Biotropica, v. 39(1), p. 120-128, 2007.

MIALHE, P. J. Preferential prey selection by Desmodus rotundus (E. Geoffroy, 1810, Chiroptera, Phyllostomidae) feeding on domestic herbivores in the municipiality of São Pedro - SP. Brazilian Journal of Biology, v. 74, n. 3, p. 579584, 2014.

NEUWEILER G. The biology of bats. Oxford University Press. New York, New York, 2000.

PIAGGIO A. J., RUSSEL A. L., OSORIO I. A., RAMÍREZ A. J., FISCHER J. W., NEUWLAD J. L., TIBBLES A. E., LEUCONA L., MCCRACKEN G. F. Genetic demography at the leading edge of the distribution of a rabies virus vector. Ecology and Evolution, v. 7, p. 5343-5351, 2017.

POLLOCK K. H., ALPIZAR-JARA R. Classical Open-population CaptureRecapture Models. Amstrup S. C., McDonald T. L., Manly B. F. J. (eds.), 2005. Handbook of capture-recapture analysis, Princeton University Press, Princeton, New Jersey.

QGIS Desktop, 2017. Versão 2.18.7.

R. Versão 3.4.3, 2017.

R Code for Mark Analysis, Package 'Rmark'. Versão 2.2.4, 2017. 
REIS N. R.; PERACCHI A. L.; PEDRO W. A.; LIMA I. P. Morcegos do Brasil. Universidade Estadual de Londrina. Londrina, 2007.

SÁNCHEZ-HERNÁNDEZ C.; ROMERO-ALMARAZ M. L.; WOOTEN M. C.; SCHNELL G. D.; KENNEDY M. L. Speed in flight of common vampire bats (Desmodus rotundus). The Southwestern Naturalist, v. 51, n. 3, p. 422-425, 2006.

SEMINÁRIO DE VIGILÂNCIA E CONTROLE DA RAIVA NO ESTADO DE SÃO PAULO. 10 ed. 2017. São Paulo. Situação Epidemiológica da Raiva no Brasil. Disponível em: http://www.saude.sp.gov.br/resources/institutopasteur/pdf/wrd/2017/palestras/situacaoepidemiologicadaraivanobrasil2017andreperes02out17.pdf. Acessado em 24 de Abril de 2018.

SILVIS, A.; FORD, W. M.; BRITZKE, E. R.; JOHNSON, J. B. Association, roost use and simulated disruption of Myotis septentrionalis maternity colonies. Behavioural processes, v. 103, p. 283-290, 2014.

SHADMEHR R., HUANG H. J., AHMED A. A. A representation of effort in decision-making and motor control. Current Biology, n. 26, p. 1929-1934, 2016.

UIEDA W. Morcegos hematófagos e a raiva em herbívoros no Brasil. Anais do seminário de Ciências da Faculdades Integradas de Uberaba nov 5-9. Uberaba, Brazil, Minas Gerais: FIUBE. P. 13-29, 1987.

VOIGT C. C.; KELM D. H. Host preference of the common vampire bat (Desmodus rotundus; Chiroptera) assessed by stable isotopes. Journal of Mammalogy, v. 87, i. 1, p. 1-6, 2006.

WILKINSON G. S. The social Organization of the common vampire bat I: pattern and cause of association. Behaviol Ecology and Sociobiology, v. 17, n. 2, p.111-121, 1985. 
WILKINSON G. S., CARTER G. G., BOHN K. M., ADAMS D. M. Non-kin cooperation in bats. Phil. Trans. R. Soc. B, v. 371, 2016.

WHO Expert Consultation on Rabies, 2 ed. WHO Technical Report Series, no. 982. World Health Organization, 2013. 
3. CAPÍTULO 2: CONSTRUÇÃO E ANÁLISE DE REDES DE CONTATO DE MORCEGOS DA ESPÉCIE Desmodus rotundus PARA A TRANSMISSÃO DO VÍRUS DA RAIVA EM AMBIENTES RURAIS 


\subsection{Resumo}

A importância do morcego hematófago da espécie Desmodus rotundus para a transmissão da raiva do meio silvestre ao meio rural não reside unicamente em sua capacidade de transmitir esta enfermidade, mas também na sua capacidade de adaptação às mudanças ambientais e climáticas, concedendoIhe uma ampla distribuição geográfica. Métodos de controle e vigilância para esta enfermidade foram então criados baseando-se no conhecimento empírico acumulado sobre a transmissão no ambiente rural. Sendo assim, apoiando-se em evidências científicas disponíveis e observações de campo, um modelo de transmissão incorporando determinantes geográficos e comportamentais do morcego hematófago foi proposto com o intuito de direcionar e otimizar as ações de vigilância epidemiológica e controle da transmissão da raiva. Este modelo foi construído por meio do método de análise de rede, do tipo bimodal, composta pela integração entre uma rede de contato entre abrigos de morcegos hematófagos e outra, de contato entre abrigos e propriedades rurais criadoras de herbívoros de interesse econômico. O modelo resultante demonstra maior significância da rede entre abrigos para a manutenção e transmissão do vírus, além da relação entre topografia e predação. O modelo foi capaz de identificar comunidades de propriedades rurais sob risco de ocorrência de raiva e em que comunidades de abrigos o vírus se mantem circulando. $O$ entendimento das interações entre morcegos e suas fontes de alimentação, influenciadas pelo ambiente, permite estabelecer medidas de vigilância e controle mais precisas e, em última instância, com uma menor relação de custo-benefício destas ações.

Palavras-chave: Desmodus rotundus. Raiva. Análise de redes. Rede de transmissão. 


\subsection{Introdução}

O morcego hematófago da espécie Desmodus rotundus tornou-se o principal responsável pela manutenção e transmissão do vírus da raiva do meio silvestre ao meio rural (CALISHER et al., 2006). A importância desta espécie de morcego não reside apenas em sua capacidade de transmitir a doença, devido à seus hábitos alimentares e sociais, mas também na sua capacidade de adaptação às mudanças ambientais e climáticas, concedendo-lhes uma ampla distribuição geográfica, do norte do México ao Uruguai (HAYES; PIAGGIO, 2018).

Métodos de controle e vigilância para a raiva foram então criados baseandose no conhecimento empírico acumulado sobre como a transmissão ocorre no ambiente rural por intermédio de morcegos hematófagos. Desde a publicação do manual técnico do PNCRH (MAPA, 2009), um sistema de vigilância baseado em risco vem sido implementado, com a incorporação de modelos qualitativos de risco (DIAS et al., 2011; BRAGA et al., 2014). Entretanto, esta metodologia vem se mostrando susceptível à falha de obtenção de informações básicas pelo sistema de vigilância da raiva, devido à grande heterogeneidade dos serviços veterinários oficiais. Além disso, pouca ênfase tem sido dada à ecologia de agentes transmissíveis em morcegos. Os dados de prevalência são atualmente compilados de sistemas de vigilância passiva e poucos estudos observacionais foram desenvolvidos a campo (KUNZ; FENTON, 2003).

Sendo assim, apoiando-se em evidências observadas em trabalhos prévios e observações de campo (descritas no capítulo anterior), um modelo de transmissão incorporando determinantes geográficos e comportamentais do morcego hematófago foi proposto com o intuito de direcionar e otimizar as ações de vigilância epidemiológica e controle da transmissão da raiva. Este modelo foi construído por meio do método de análise de redes, uma metodologia analítica bem fundamentada e muito utilizada na área da saúde (GRISI FILHO, 2012).

O conceito de redes é utilizado para verificar, por exemplo, como a movimentação de animais e/ou pessoas pode influenciar na introdução e expansão de enfermidades, os riscos ao sistema produtivo e a traçar estratégias de controle (GREEN; GREGORY; MUNRO, 2009). Uma rede é um conjunto de nós conectados entre si através de arestas, sendo os nós a representação de indivíduos ou unidades epidemiológicas e as arestas as interações entre estes. 
Estas redes podem ainda englobar comunidades, que são conjuntos de nós relacionados entre si de maneira significativa, compartilhando características (NEWMAN, 2006). Este tipo de análise poderia ser empregado para melhor entender a raiva, poderia auxiliar aos serviços oficiais à tornarem seus métodos de controle mais efetivos e acima de tudo, poderia trazer maior clareza sobre como colônias de morcegos $D$. rotundus, propriedades rurais, comunidades humanas e o ambiente que os cerca estão relacionados, conectados e interagindo entre si.

O objetivo deste trabalho é a construção de redes de contato entre abrigos de morcegos da espécie $D$. rotundus e propriedades rurais criadoras de herbívoros de interesse econômico e outros abrigos de morcegos da mesma espécie. Determinantes topográficos foram atribuídos à estas redes de forma a explorar a dispersão e manutenção do vírus da raiva nestes ambientes de forma mais abrangente, com a formação de comunidades, ou nichos ecológicos.

\subsection{Materiais e métodos}

\subsubsection{Desenho do estudo}

Para verificar como a topografia tem influência na determinação das fontes de alimentação de morcegos da espécie $D$. rotundus utilizou-se de análises espaciais. A área de estudo foi selecionada em continuidade a trabalhos prévios realizado na região, onde características comportamentais dos morcegos foram observadas (descritas no capítulo anterior). Além disso, esta é uma das regiões mais trabalhadas e estudadas pela CDA na vigilância de abrigos de morcegos hematófagos para controle da raiva em herbívoros. Desta forma, as premissas deste trabalho são:

1. Limite máximo de vôo para forrageio $=10 \mathrm{~km}$ (LORD, 1993; MEDINA et al., 2007; MAPA, 2009);

2. Morcegos tendem a forragear em fontes de alimentação localizadas a cotas de nível mais baixas que seus abrigos de origem (capítulo anterior). Desta forma, um coeficiente de friç̧ão (dificuldade para os morcegos irem 
se alimentar e voltarem aos abrigos) é dado pela inclinação entre o abrigo e a propriedade rural (POLO et al., 2015).

Os dados de abrigos cadastrados, focos de raiva e propriedades rurais cadastradas foram cedidos pela Coordenadoria de Defesa Agropecuária do Estado de São Paulo (CDA). Os 260 abrigos da área de estudo foram registrados em decorrência de busca ativa, sendo revisitados pelo menos uma vez ao ano pelos técnicos da CDA no período entre 2013 e 2017. As ocorrências de focos de raiva são provenientes do sistema de vigilância passiva do Programa Estadual de Controle da Raiva de Herbívoros. A localização das propriedades rurais é proveniente do cadastro de propriedades rurais do Estado de São Paulo, mantido e atualizado pela CDA, no ano de 2015. O modelo de elevação digital da área de estudo foi obtido no banco de dados U.S. Geological Survey.

Duas redes distintas foram construídas, uma relacionando abrigos de Desmodus rotundus e propriedades rurais, e outra relacionando a conexão entre abrigos, uma vez que morcegos de diferentes abrigos interagem entre si, seja para a disputa por fêmeas, para reprodução ou ainda para a disputa de melhores abrigos (CARTER; LEFFER, 2015; WILKINSON, 1985; WILKINSON et al., 2016; KUNZ; FENTON, 2013). Estas duas redes são distintas com dois tipos de nós, propriedades rurais e abrigos, porém compartilham um mesmo tipo de nó: os abrigos, sendo assim, teremos a construção de uma rede bimodal (ZHOU et al., 2007). A rede entre abrigos e propriedades rurais é do tipo direcionada, enquanto que a rede entre abrigos é do tipo não-direcionada (GRISI FILHO, 2012).

\subsubsection{Metodologia para construção da rede entre abrigos e propriedades rurais}

$\mathrm{Na}$ rede entre abrigos e propriedades rurais, tanto os abrigos quanto as propriedades rurais foram representados como nós com mesmo peso e as arestas, representando as conexões, tiveram peso atribuído por determinantes topográficos.

Antes da construção da rede de abrigos, foram identificadas as áreas de uso de cada abrigo, a fim de determinar quais propriedades rurais poderiam ser utilizadas como fontes de alimentação para cada abrigo. À titulo de melhor compreensão da construção das áres de uso e da rede, atribuiu-se o nome 
"Objeto" para o conjunto de polígonos, pontos e informações georreferenciados processados. O fluxo para construção destes pode ser visualizado na Figura 3.1.

Figura 3.1 - Fluxograma de construção da rede entre abrigos e propriedades rurais.

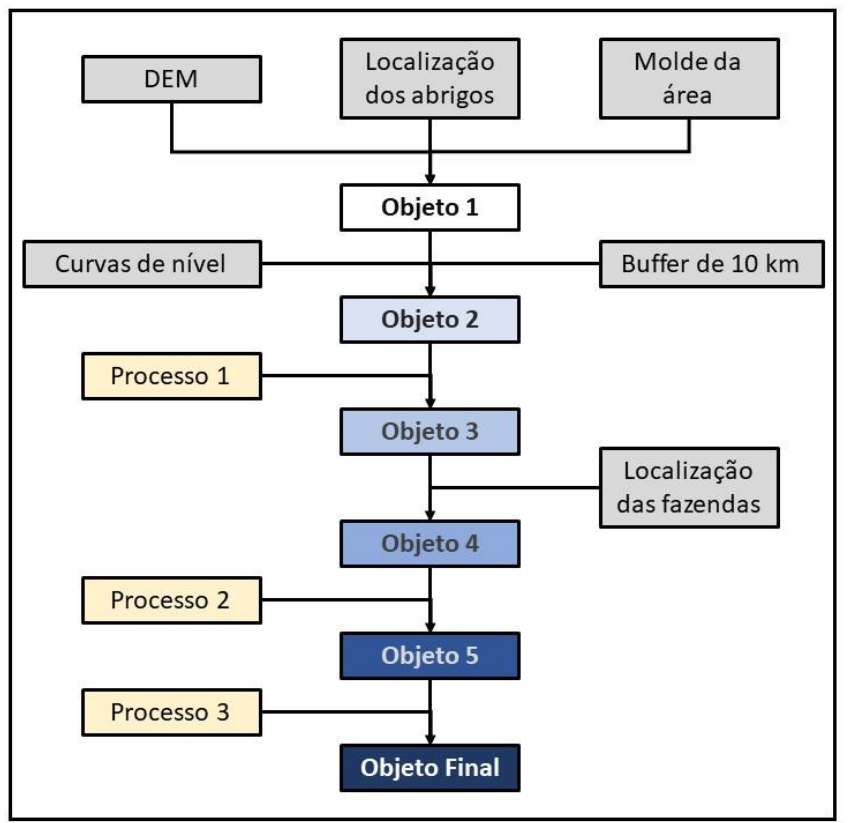

Dados base: DEM da região, coordenadas dos abrigos

e molde da área de estudo;

Objetos:

1. Mapa compilando contorno da área em estudo, elevação digital do terreno e localização dos abrigos;

2. Objeto 1 com adição de curvas de nível da elevação do terreno com uma área de 10 quilômetros ao redor de cada abrigo;

3. Objeto 2 com adição das "áreas de influência" de cada abrigo;

4. Objeto 3 com adição das fazendas da área de estudo;

5. Objeto 4 com adição de informação sobre à que "áreas de uso" pertence cada fazenda.

Processos:

1. Formação das "áreas de influência";

2. Contagem de quantas e quais fazendas estão dentro da "área de influência" de cada abrigo;

3. Formação da rede de abrigos e fazendas.

Objeto Final: Mapa contendo rede de interação entre abrigos e fazenda.

Criou-se um objeto único (Objeto 1) contendo informações para determinar a área de uso de cada abrigo: Camada do modelo digital de elevação (acrônimo em inglês, DEM) do terreno da área de estudo, camada com o limite dos municípios que compõem a área de estudo e camada com a localização dos abrigos registrados durante o período de 2013 a 2017 pela equipe de controle de raiva em herbívoros da CDA.

A partir do modelo de elevação digital, foram obtidos polígonos dados pela elevação menor ou igual à cota de elevação de cada abrigo (Objeto 2). Estes polígonos foram então editados, a uma distância de até $10 \mathrm{~km}$ a partir do abrigo correspondente, a fim de gerar as áreas de influência para os 260 abrigos cadastrados na área de estudo (Processo 1). O resultado foi o mesmo mapa contendo a delimitação da área de estudo, os pontos dos abrigos, o modelo de elevação digital e as áreas de influência de cada abrigo (Objeto 3).

Sobre as áreas de uso dos abrigos, adicionou-se pontos correspondentes às coordenadas das propriedades rurais criadoras de herbívoros de interesse econômico, cadastradas pela CDA, durante o ano de 2015 (Objeto 4). Por meio de ferramentas de contagem de pontos em polígonos, contou-se em quantas e 
a quais áreas de uso cada propriedade rural estava contida (Processo 2). Este processo adicionou à camada de propriedades rurais a informação de qual(quais) área(s) de uso uma dada propriedade rural pertence, uma vez que cada área de uso estava identificada de acordo com o abrigo correspondente (Objeto 5). Desta forma é possível saber inclusive quais os abrigos potencialmente atendidos por cada propriedade rural para forrageio.

Por fim, foram criadas as conexões entre propriedades rurais e abrigos, sendo cada propriedade rural conectada ao abrigo correspondente à área de influência em que estava contida (Processo 3). Caso uma dada propriedade rural estivesse contida dentro de áreas de influência de diferentes abrigos, criaram-se várias conexões, cada qual com seu abrigo correspondente (Objeto Final). Todo este processo resultou em um objeto contendo as conexões entre abrigos e possíveis propriedades rurais utilizadas como fonte de alimentação. Estas análises foram feitas no programa de computador GEPHI versão 0.9.2 (GEPHI, 2017). As Figuras 3.2A e 3.2B ilustram a construção da área de influência de um abrigo como exemplo através de uma visão aérea da topografia e por um corte vertical do terreno, respectivamente.

Levando-se em consideração as premissas apontadas anteriormente, foram calculadas medidas e valores para caracterização da rede entre abrigos de $D$. rotundus e propriedades rurais: (a) acessibilidade entre cada abrigo e propriedades rurais em sua área de uso; (b) capacidade de suporte provável de cada abrigo; (c) número potencial de morcegos utilizando cada fonte de alimentação; (d) grau de influência de entrada de cada nó (propriedade rural) e (e) detecção e delimitação de comunidades na rede. Na criação da rede (itens b, c, d e e), atribuiu-se um peso às arestas (conexões entre abrigos e propriedades rurais), dado pela acessibilidade existente entre $\mathrm{o}$ abrigo e a fonte de alimentação. 
Figura 3.2A: Visão aérea da área de uso do abrigo 63.

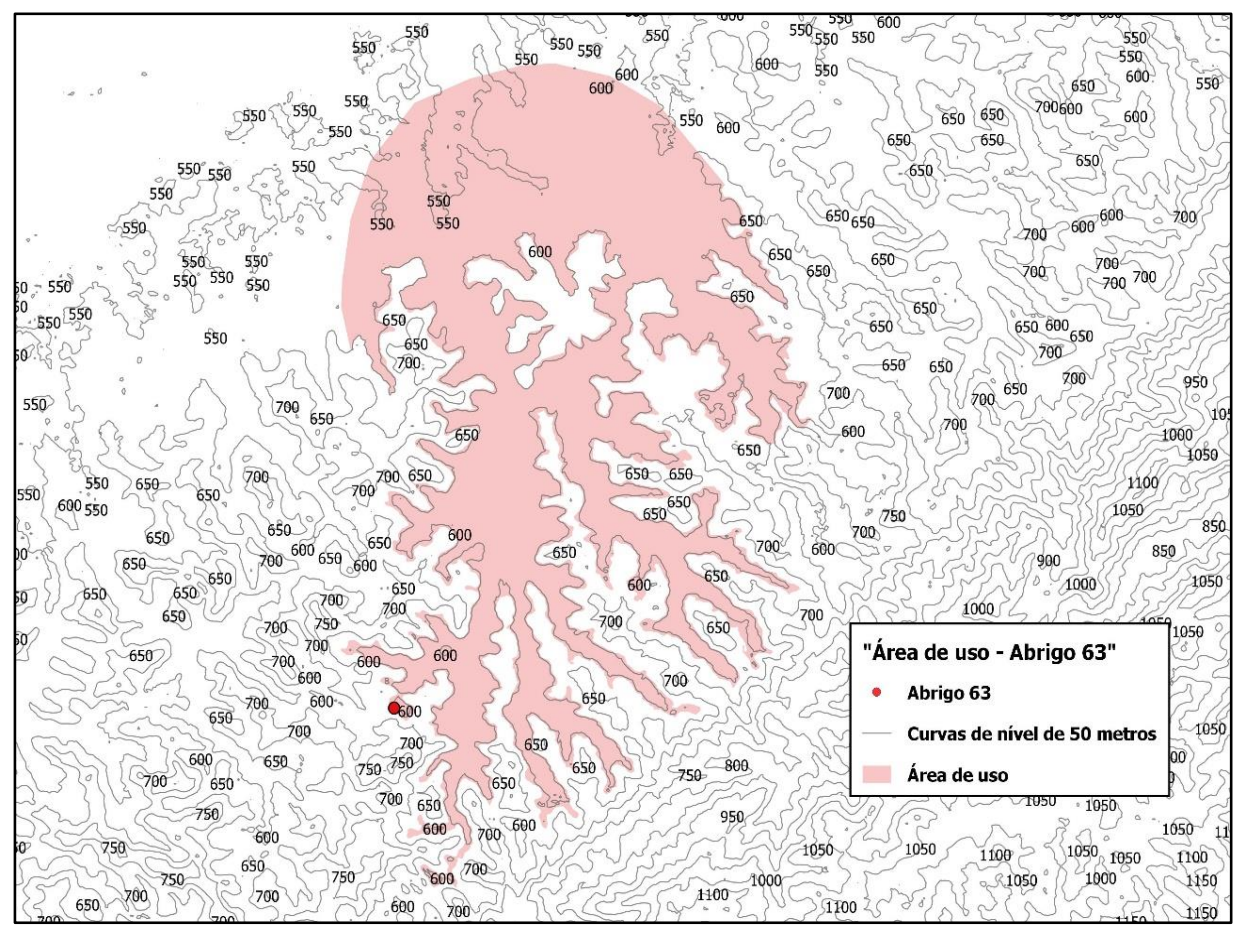

Figura 3.2B: Corte vertical da área de uso do abrigo 63.

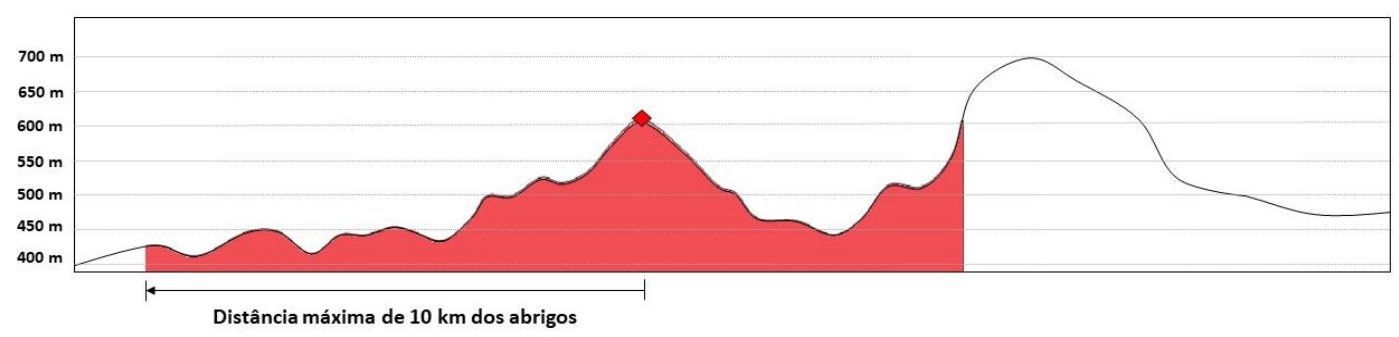

Figura 3.3 - Fluxograma dos resultados obtidos a partir da rede entre abrigos e propriedades rurais.

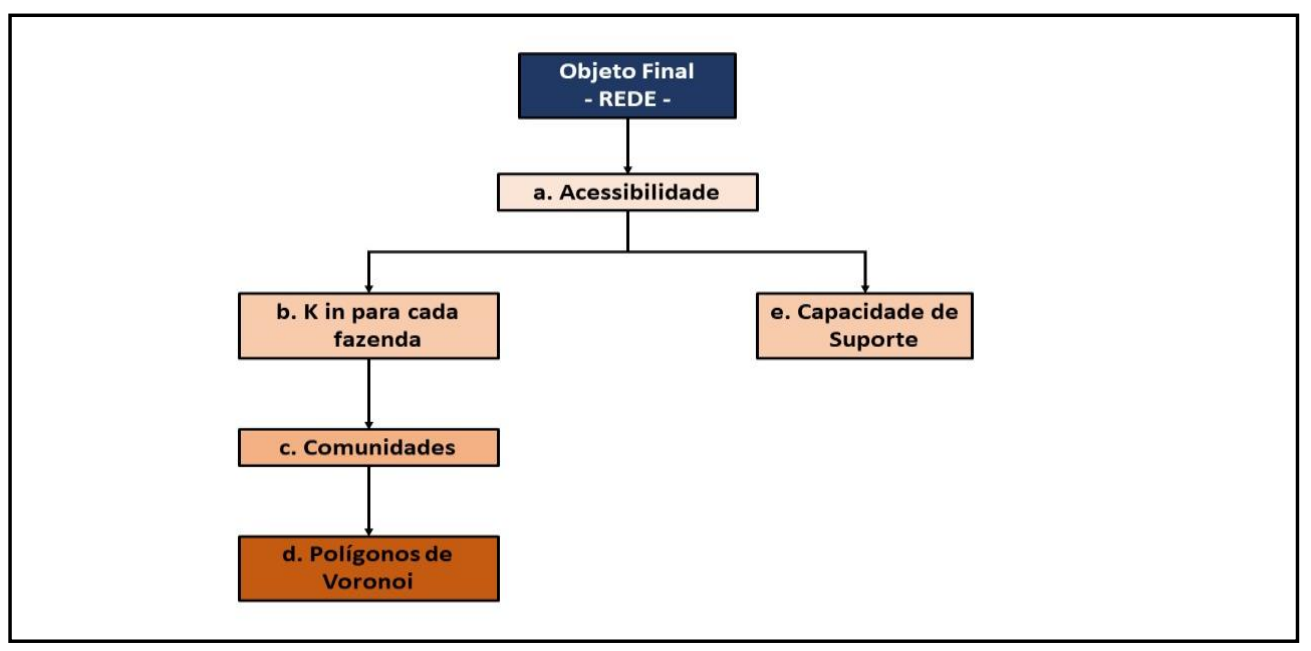




\subsubsection{Acessibilidade}

Este parâmetro refere-se à dificuldade com a qual cada fonte de alimentação é alcançada por morcegos hematófagos a partir de um abrigo. O cálculo foi baseado no modelo de área de influência flutuante em dois passos, proposto por Radke e Mu (2009) e modificado por Polo et al. (2015). O primeiro passo do modelo é o cálculo do peso de competição Gaussiano $\left(W_{i j}\right)$ entre os abrigos $i \mathrm{e}$ as propriedades rurais $j$ :

$$
W_{i j}=\frac{1}{\sum_{j \in\left\{d_{i j}<10 \mathrm{~km}\right\}} N_{i j}}
$$

$d_{i j}$ é a distância entre um abrigo e uma propriedade rural na área de influência e $N_{i j}$ é o número de propriedades rurais na área de influência do abrigo $i$.

O peso de competição Gaussiano determina que a demanda por uma dada propriedade rural é afetada pela proximidade com outras propriedades rurais. Assim, para um abrigo $i$, haverá uma maior acessibilidade entre propriedades rurais na sua área de influência devido à demanda reduzida nas propriedades rurais. $O W_{i j}$ será igual a 1 se somente uma propriedade rural estiver presente em sua área de influência e diminui conforme o número de propriedades rurais alternativas aumenta.

O segundo passo é o cálculo da impedância Gaussiana $\left(G_{i j}\right)$ para cada aresta da rede de contato:

$$
G_{i j}=\frac{e^{-\beta\left(\frac{d_{i j}{ }^{2}}{d_{0}}\right)^{2}}-e^{-\beta}}{1-e^{-\beta}}
$$

sendo $\beta$ o coeficiente de friç̧ão, representando a dificuldade do deslocamento do abrigo até a fonte de alimentação, ou seja, a inclinação, dada pela diferença entre a elevação do abrigo e a propriedade rural dividido pela distância Euclideana entre estes pontos.

O terceiro passo é o cálculo da razão entre propriedades rurais e abrigos, ou seja a razão entre oferta (capacidade de fornecer alimento das propriedades rurais aos morcegos) e demanda (população de morcegos a se alimentar por noite) $\left(R_{j}\right)$ : 


$$
R_{j}=\frac{S_{j}}{\sum_{i \in\left\{d_{i j}<10 k m\right\}}\left(P_{i} * G_{(d i j, d o *} * W_{i j}\right)}
$$

sendo $S_{j}$ a capacidade da propriedade rural $j$ de alimentar morcegos do abrigo $i$, dado pelo número de propriedades rurais, e $P_{i}$ a população de morcegos potencialmente atendida de um abrigo $i$, multiplicado pelo número de abrigos com conexão com esta dada propriedade rural. Para os fins deste trabalho, o valor de $R_{j}$ será fixado em 1 (um), ou seja, toda propriedade $j$ teria capacidade de suprir a totalidade de morcegos que compoem a população de um abrigo $i$.

O quarto e último passo é buscar todas as propriedades rurais nas áreas de influência de cada abrigo $i$.

$$
A_{i}=\sum_{i \in\left\{d_{i j}<10 k m\right\}} W_{i j} R_{j} G_{\left(d_{i j}, d_{0}\right)}
$$

Estes cálculos foram realizados no programa de computador QGIS versão 2.18.7 (QGIS, 2017).

\subsubsection{Detecção e delimitação de comunidades}

Para a determinação das comunidades entre abrigos e propriedades rurais, atribuiu-se o valor de acessibilidade como peso de cada aresta da rede. Todos os nós receberam o mesmo peso. Empregou-se método de Louvain para detecção de comunidades (BLONDEL et al., 2008), mantendo valor de resolução em 1. Este cálculo foi realizado no programa de computador GEPHI versão 0.9.2 (GEPHI, 2017). Finalmente, foram determinados polígonos de Voronoi para cada propriedade rural (REEM, 2010), sendo que os polígonos correspondentes a cada comunidade foram agrupados, originando a delimitação espacial contínua de cada comunidade de propriedades rurais, dada pelos abrigos. Este procedimento foi realizado no programa de computador QGIS versão 2.18.7 (QGIS, 2017).

Após a construção da rede entre abrigos e propriedades rurais, criou-se a rede entre abrigos. Ao comparar as elevações de abrigos ora classificados como maternidade e de machos pela CDA, observou-se que nas proximidades de abrigos de machos, os abrigos maternidades localizavam-se tanto a elevações 
maiores quanto menores. Desta forma, a aproximação utilizada para a determinação da rede de abrigos e propriedades rurais, considerando fontes de alimentação a elevações iguais ou inferiores à dos abrigos correspondentes, não seria aplicável.

Sugere-se que na disputa por fêmeas, os morcegos machos possam recorrer a abrigos de fêmeas em elevações acima das dos seus abrigos de origem. Com a localização em coordenadas dos abrigos, traçou-se um círculo com raio de 10 $\mathrm{km}$ a partir de cada abrigo, sendo as conexões formadas com todos os abrigos dentro de sua respectiva área (LORD, 1993; MEDINA et al., 2007; MAPA, 2009). O peso atribuído a cada conexão foi o mesmo. Abrigos centrais, com maior número de vizinhos, possuiriam um maior número de conexões e por consequente um maior grau de entrada na rede entre abrigos. Para construção desta rede foi utilizado o software QGIS versão 2.18.7 (QGIS, 2017).

Após a criação da rede de conexões entre abrigos vizinhos, foi possível realizar o cálculo do grau de entrada para cada nó (abrigo) e grau médio (GRISI FILHO, 2012):

$$
\begin{aligned}
& K_{\text {in }, i}=\sum_{j=1}^{n} a_{i j} \\
& K_{\text {out }, i}=\sum_{j=1}^{n} a_{i j} \\
& {\left[K_{\text {in }}\right]=\left[K_{\text {out }}\right]=\frac{[K]}{2}}
\end{aligned}
$$

As comunidades foram determinadas adotando mesma metodologia empregada para detecção de comunidades na rede entre abrigos e propriedades rurais, utilizando-se o programa GEPHI versão 0.9.2 (GEPHI, 2017).

\subsubsection{Metodologia para análise estatística das redes}

Com o objetivo de testar as hipóteses levantas, alguns testes estatísticos foram realizados no programa $\mathrm{R}$ para caracterizar e melhor analisar as redes formadas. Inicialmente, os graus de entrada para as propriedades rurais e os graus médios para os abrigos foram separados por comunidade e submetidos ao teste de Shapiro-Wilk para verificar se as observações estam distribuídas de forma normal. Em seguida, o teste de Bonferroni foi realizado cruzando os graus 
médios por comunidade com o intuito de verificar semelhança entre as distribuições de cada comunidade.

Outras variáveis oriundas das redes construídas foram analisadas: altitude dos abrigos; altitude das propriedades rurais; quantidade de propriedades rurais conectadas a cada abrigo; ocorrência de raiva em propriedades rurais; ocorrência de casos de raiva em propriedades rurais dentro das áreas de uso de cada abrigo e; total de casos de raiva que ocorreram dentro das áreas de uso de cada abrigo.

Na tabela 3.1 é possível verificar quais testes foram empregados para verificar correlação entre estas variáveis variáveis. O objetivo da realização destes testes era verificar se havia algum fator de confusão influenciando os resultados das redes e verificar se há relação entre a topografia dos abrigos e das propriedades rurais para o comportamento de escolha do local para predação. O tipo de teste foi escolhido baseado nos tipos de variáveis correlacionadas.

Tabela 3.1 - Relação de testes estatísticos aplicados às redes. A tabela apresenta quais as variáveis testadas e o tipo (quantitativa ou qualitativa) justificando o teste estatístico empregado.

\begin{tabular}{lll}
\hline Variáveis & Tipo & Teste estatístico \\
\hline Altitude dos abrigos & Quantitativa & Regressão linear \\
K dos abrigos & Quantitativa & \\
Altitude dos abrigos & Quantitativa & Regressão linear \\
Número de fazendos conectadas a cada abrigo & Quantitativa & \\
K dos abrigos & Quantitativa & \\
Total de ocorrência de raiva dentro de cada área & Quantitativa & Regressão linear \\
de uso & & \\
K dos abrigos & Quantitativa & Regressão linear \\
Número de fazendos conectadas a cada abrigo & Quantitativa & \\
Altitude das propriedades rurais & Quantitativa & Regressão linear \\
K in das propriedades rurais & Quantitativa & \\
Altitude dos abrigos & Quantitativa & Teste T \\
Ocorrência de raiva dentro de cada área de uso & Qualitativa & \\
K dos abrigos & Quantitativa & Teste T \\
Ocorrência de raiva dentro de cada área de uso & Qualitativa & Teste T \\
Número de fazendos conectadas a cada abrigo & Quantitativa & Qualitativa \\
Ocorrência de raiva dentro de cada área de uso & Quantitativa & Teste T \\
Altitude das propriedades rurais & Qualitativa & \\
Ocorrência de raiva dentro de cada área de uso & Quantitativa & \\
K in das propriedades rurais & Qualitativa & \\
Ocorrência de raiva nas propriedades rurais & & Teste \\
\hline
\end{tabular}




\subsection{Resultados}

No banco de dados havia um total de 260 abrigos de morcegos $D$. rotundus e 1.644 propriedades rurais na área de estudo. A rede entre abrigos e propriedades rurais conectou os 260 abrigos a 1.557 propriedades rurais através de 7.355 arestas (conexões). Cada abrigo estava em média conectado à 28,28 propriedades rurais (varianda de 01 a 139 conexões), enquanto que cada propriedade rural estava em média conectado à 4,37 abrigos (varianda de 01 a 18 conexões). Foram obtidas 14 comunidades de propriedades rurais e abrigos de morcegos, utilizando-se o valor de accessibilidade como peso das arestas.

A rede entre abrigos resultou em 1.922 conexões, sendo que cada abrigo estava conectado, em média, a 7,48 outros abrigos (variando de 01 a 24 conexões). Por sua vez, estes abrigos foram agrupados em 9 comunidades.

$\mathrm{Na}$ Figura 3.4 estão representadas as áreas de uso dos abrigos, na região estudada. As redes entre abrigos e entre abrigos e propriedades rurais podem ser visualizadas nas Figuras 3.5. A localização dos casos de raiva na região, que estariam relacionados às comunidades tanto de propriedades rurais quanto a de abrigos são apresentados na Figura 3.6. 
Figura 3.4 - As áreas de uso dos abrigos cadastrados da área de estudo

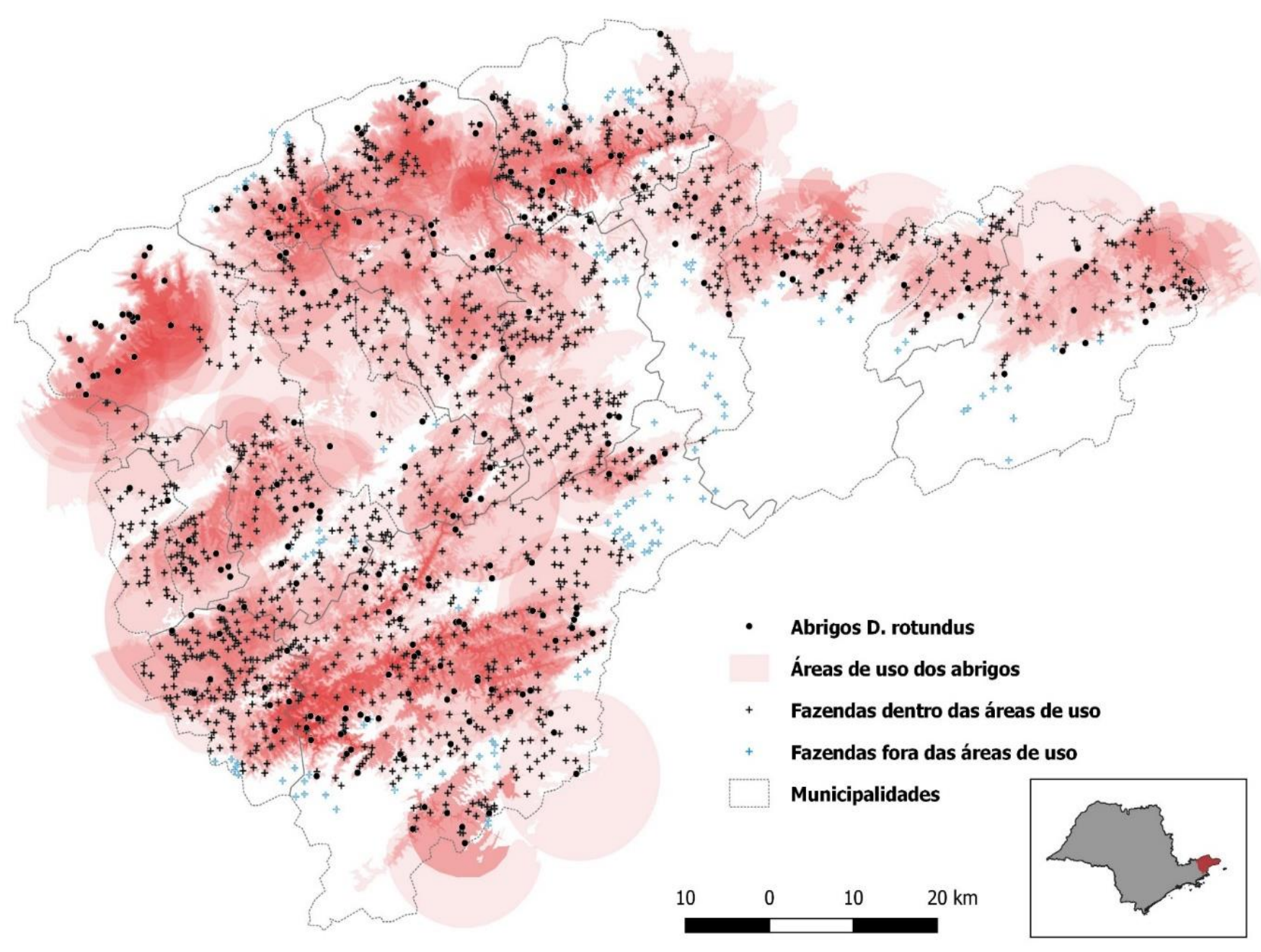

Observação: As áreas de uso estão representas pela tonalidade vermelha. Maior intensidade da cor representa maior sobreposição de áreas de uso. 
Figura 3.5 - As redes entre abrigos e entre abrigos e propriedades rurais com as áreas de uso (rede bipartida)

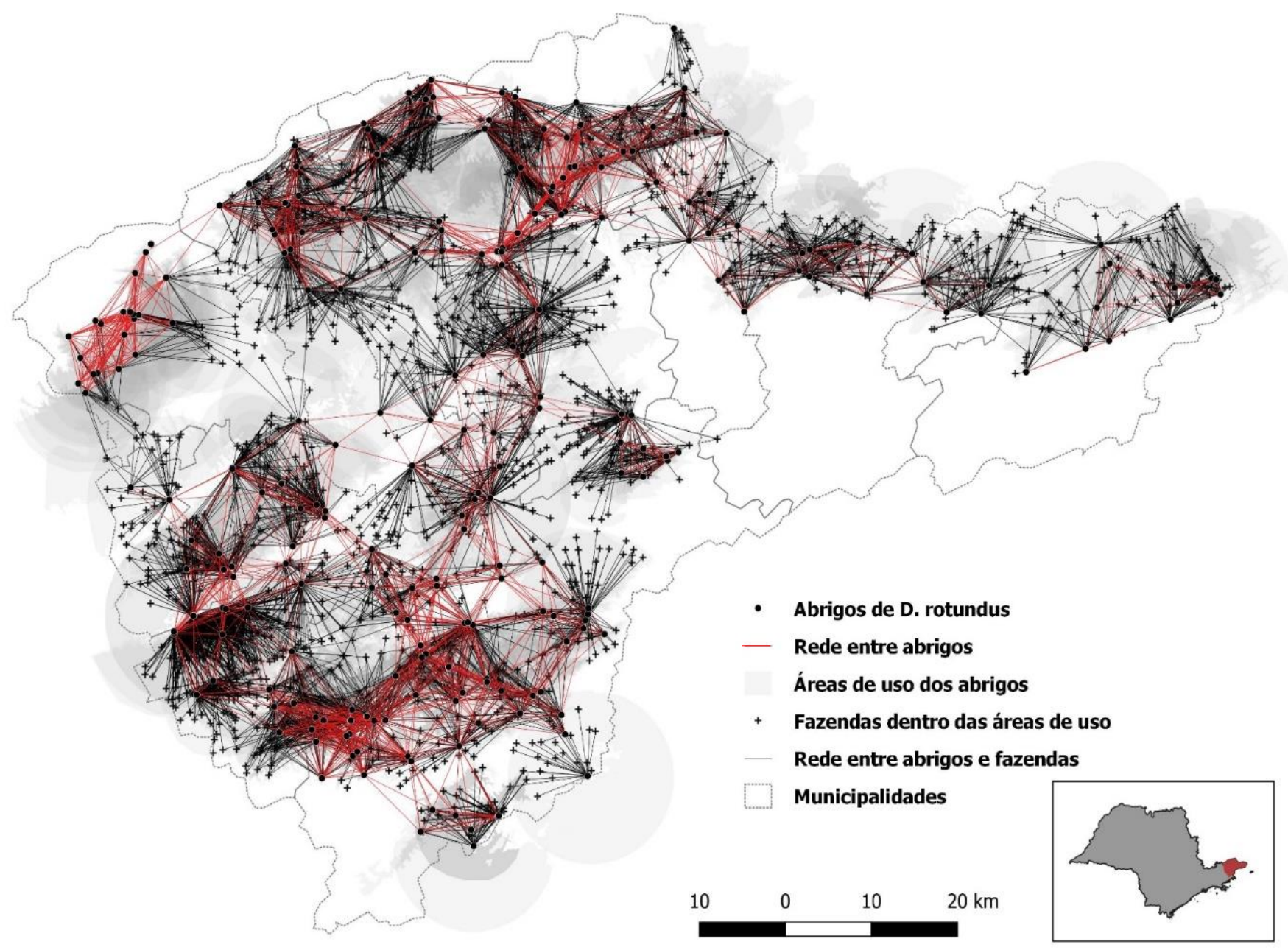

Observação: As áreas de uso estão representas pela tonalidade cinza. Maior intensidade da cor representa maior sobreposição de áreas de uso. 
Figura 3.6 - Comunidades de abrigos e propriedades rurais com as ocorrências de raiva em herbívoros

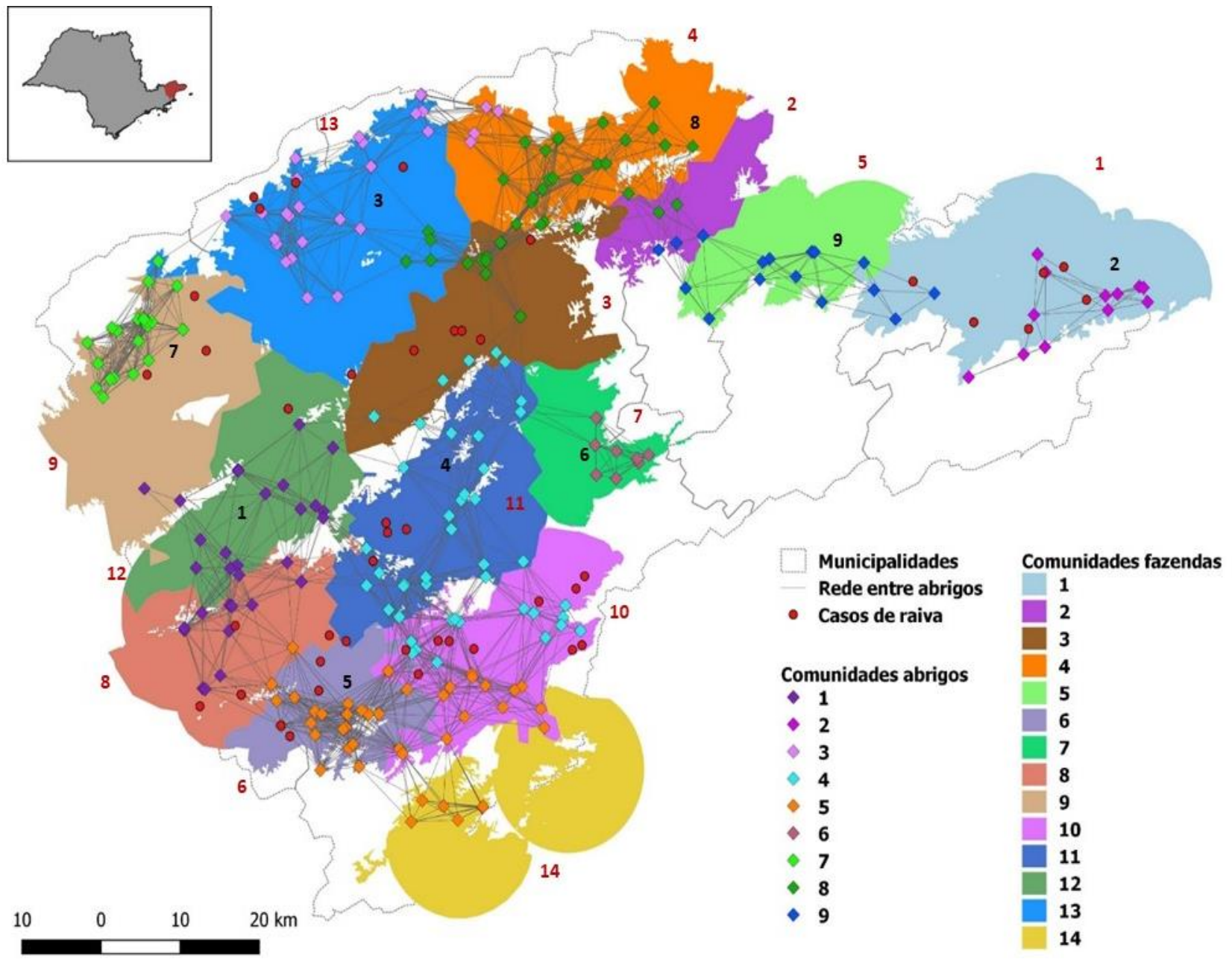

Observação: Os números em vermelho indicam as comunidades de propriedades rurais e os números em preto indicam as comunidades de abrigos, ambos correspondentes à legenda. 
$\mathrm{Na}$ Figura 3.7A são apresentados os valores de grau de entrada para as propriedades rurais da rede entre abrigos e propriedades rurais. Na Figura 3.7B são apresentados os valores de grau médio para os abrigos da rede entre abrigos.

Figura 3.7A - Boxplot do grau de entrada das propriedades rurais por comunidade.
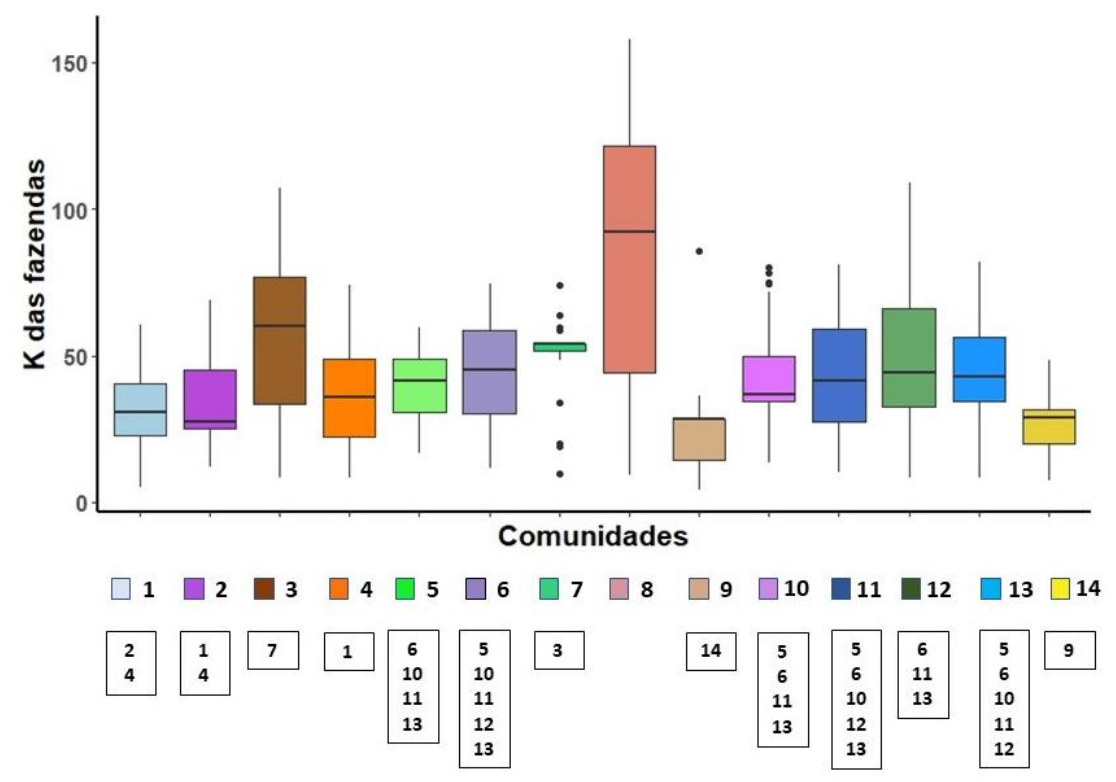

Figura 3.7B - Boxplot do grau médio dos abrigos por comunidade de abrigo.

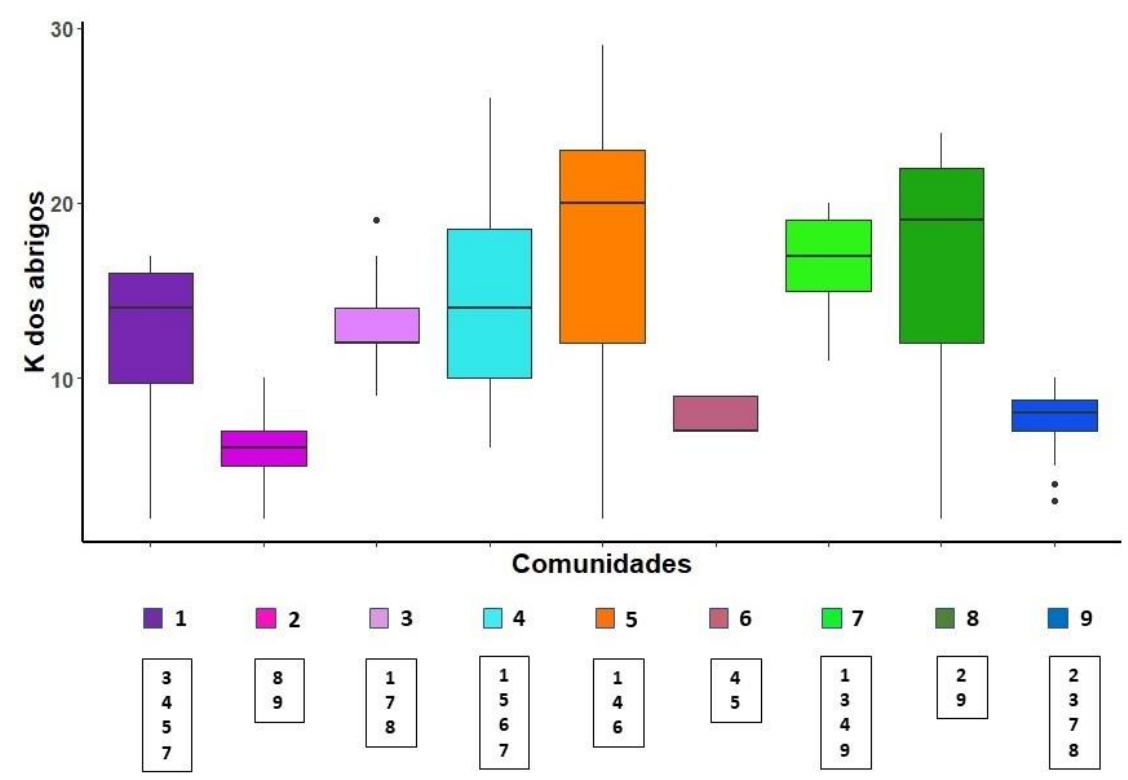

Observação: Os números indicados nas caixas abaixo de cada boxplot indicam quais comunidades possuem graus iguais ao da comunidade indicada. 
Nota-se que, na comunidade de propriedades rurais, a comunidade 08 tem 0 maior grau mediano, seguido pelas 03 e 07 . Com relação à comunidade de abrigos, praticamente não desponta nenhuma, pois a comunidade que tem 0 maior grau mediano (comunidade 05) é igual às comunidades 01, 04 e 06 (essa possui um dos menores graus medianos). Não há uma correlação do grau da comunidade de abrigos às comunidades de propriedades rurais sobrepostas, ou seja, elevados graus em comunidades de abrigos não são acompanhados por elevados graus nas comunidades sobrepostas.

Com relação à rede de abrigos, nota-se que as comunidades 05,07 e 08 possuem maiores graus médios, enquanto que na rede de propriedades rurais e abrigos, a comunidade 08 possui maior grau de entrada. Entretanto, a comunidade de abrigos 05 está sobreposta às comunidades 06 e 10 de propriedades rurais, a comunidade de abrigos 07 está sobreposta às comunidades 09 e 13 das propriedades rurais e, por fim, a comunidade de abrigos 08 está sobreposta às comunidades 03, 04 e 13.

Os casos de raiva ocorreram nas comunidades de propriedades rurais 01,03 , $06,08,09,10,11,12$ e 13. Apenas quatro comunidades de propriedades rurais não tiveram ocorrências de raiva (comunidades 02, 04, 05 e 07). As comunidades de abrigos 01, 02, 03, 04, 05, 07, 08 e 09 estão sobrepostas as estas comunidades de propriedade rural com ocorrência de raiva foram as comunidades. Apenas a comunidade 05 de abrigos não está sobreposta à uma comunidade de propriedades rurais com ocorrência de raiva.

Quanto às análises estatísticas aplicadas aos parâmetros das redes, os resultados com respectivos valores de significância podem ser visualizados na Tabela 3.2. Foi observada correlação positiva entre: (a) a altitude das propriedades rurais e o valor de grau de entrada destas, (b) a altitude dos abrigos com o grau médio dos abrigos da rede entre abrigos e (c) o grau médio de abrigos com a ocorrência de raiva dentro das respectivas áreas de uso.

Além disso, foi observada correlação positiva entre (a) a altitude dos abrigos e o número de propriedades rurais conectadas a estes abrigos, (b) o grau médio dos abrigos e o total de ocorrência de casos de raiva ocorrendo dentro da área de uso destes abrigos e, por fim, (c) o número de propriedades rurais conectadas a cada abrigo com a ocorrência de raiva dentro da área de influência de cada abrigo. 
Tabela 3.2 - Resultados dos testes estatísticos aplicados aos parâmetros das redes.

\begin{tabular}{|c|c|c|}
\hline Variáveis & Teste estatístico & p Value \\
\hline $\begin{array}{l}\text { Altitude dos abrigos } \\
\text { K dos abrigos }\end{array}$ & Regressão linear & 0.4547 \\
\hline $\begin{array}{l}\text { Altitude dos abrigos } \\
\text { Número de fazendos conectadas a cada abrigo }\end{array}$ & Regressão linear & $3.59^{*} e-08$ \\
\hline $\begin{array}{l}\text { K dos abrigos } \\
\text { Total de ocorrência de raiva dentro de cada área de uso }\end{array}$ & Regressão linear & $1.86^{*} e-06$ \\
\hline $\begin{array}{l}\text { K dos abrigos } \\
\text { Número de fazendos conectadas a cada abrigo }\end{array}$ & Regressão linear & 0.2521 \\
\hline $\begin{array}{l}\text { Altitude das propriedades rurais } \\
\mathrm{K} \text { in das propriedades rurais }\end{array}$ & Regressão linear & 0.00564 \\
\hline $\begin{array}{l}\text { Altitude dos abrigos } \\
\text { Ocorrência de raiva dentro de cada área de uso }\end{array}$ & Teste t & 0.001376 \\
\hline $\begin{array}{l}\text { K dos abrigos } \\
\text { Ocorrência de raiva dentro de cada área de uso }\end{array}$ & Teste t & 0.005364 \\
\hline $\begin{array}{l}\text { Número de fazendos conectadas a cada abrigo } \\
\text { Ocorrência de raiva dentro de cada área de uso }\end{array}$ & Teste $t$ & $3.56^{\star} e-05$ \\
\hline $\begin{array}{l}\text { Altitude das propriedades rurais } \\
\text { Ocorrência de raiva nas propriedades rurais }\end{array}$ & Teste $\mathrm{t}$ & 0.8166 \\
\hline $\begin{array}{l}\text { K in das propriedades rurais } \\
\text { Ocorrência de raiva nas propriedades rurais }\end{array}$ & Teste $\mathrm{t}$ & 0.9207 \\
\hline
\end{tabular}

\subsection{Discussão}

Em comparação aos outros Estados brasileiros, São Paulo é o que gera a maior quantidade de informação relacionada à abrigos de morcegos $D$. rotundus e, além disso, a área de estudo, além de ser historicamente endêmica para a raiva em herbívoros, é uma região já estudada e trabalhada pela CDA e pesquisadores (DIAS et al., 2011; FERRARI et al., 2011).

Os morcegos da espécie $D$. rotundus tendem a forragear nas propriedades rurais mais próximas dos abrigos, devido ao seu comportamento sedentário, 
apesar de poderem alcançar distâncias de até $10 \mathrm{~km}$ a partir de seus abrigos (LORD, 1993; MEDINA et al., 2007; MAPA, 2009). No tocante à definição das áreas de uso para forrageamento, um raio de $10 \mathrm{~km}$ de distância foi utilizado, entretanto, a tendência de forrageamento nas fontes de alimentação mais próximas foi representada pela acessibilidade, que considerou não somente a distância, mas também a diferença de altitude entre um dado abrigo e as propriedades rurais. Desta forma, uma maior acessibilidade foi atribuída aos abrigos cujas propriedades rurais em sua área de uso estavam mais próximas e a uma menor diferença de altitude. Por outro lado, quanto maior a densidade de propriedades dentro da área de uso do abrigo, maior a oferta de fontes de alimento alternativas, resultando em menor acessibilidade.

A acessibilidade foi o parâmetro utilizado para atribir-se valor as interações entre abrigos de morcegos e propriedades rurais. Este parâmetro é muito explorado para estudar a interação e utilização de serviços de saúde pela população (Polo et al., 2015). Dentre os determinantes da acessibilidade, a razão oferta de alimento e morcegos hematófagos $(R j)$ recebeu valor 1 (um), ou seja, cada propriedade rural teria animais para alimentar uma colônia como um todo. Tal saída foi utilizada uma vez que não há conhecimento suficiente para determinar a quantidade de morcegos que cada herbívoro doméstico teria condições de alimentar, sendo assim, a acessibilidade foi determinada pelo fator de competição e oferta de propriedades rurais (Wij) e pela dificuldade de alcançar a propriedade saindo de um abrigo (Gij).

Os resultados indicam que não há uma correlação do grau da comunidade de abrigos às comunidades de propriedades rurais sobrepostas, ou seja, elevados graus em comunidades de abrigos não são acompanhados por elevados graus nas comunidades sobrepostas. Isso indica que a localização do abrigo determina o quão relacionado com os abrigos vizinhos ele será, mas não a maior disponibilidade de fontes de alimentação.

O grau médio dos abrigos apresentou associação com a ocorrência de raiva dentro da área de influência destes mesmos abrigos por meio de teste t. 0 mesmo foi observado para o grau médio dos abrigos com o total de casos de raiva ocorrendo dentro das áreas de influência de cada abrigo, indicando que quanto maior o grau dos abrigos para a rede entre abrigos, maior o número de casos de raiva ocorrendo na área de influência deste abrigo. Estas associações 
indicam maior importância da rede entre abrigos para manutenção e transmissão do vírus da raiva que a rede entre abrigos e propriedades rurais, como esperado, biologicamente. As demais associações realizadas também apontam para esta interpretação.

Quanto maior a altitude de um abrigo, maior o número de propriedades rurais que contidas dentro dela. O mesmo pode ser observado na correlação positiva entre a altitude do abrigo e a ocorrência de raiva dentro de suas respectivas áreas de influência. Esta ultima correlação estaria mais ligada ao fato do número de propriedades rurais dentro da área de influência do abrigo que à alguma real influência da altitude na transmissão da raiva, também como esperado biologicamente.

Outra correlação significativa foi o número de propriedades rurais conectadas a um abrigo com a ocorrência de raiva na área de influência deste abrigo. Ou seja, quanto mais propriedades rurais conectadas a um abrigo, maior a probabilidade de transmissão do vírus para populações de herbívoros de interesse econômico.

O tamanho dos abrigos foi dado atribuindo-se o peso das arestas (conexões) para cálculo do tamanho populacional. A oferta de fontes de alimentação dentro da área de influência de um determinado abrigo é determinante para estimação do tamanho populacional do abrigo, ou seja, quanto mais propriedades rurais e mais próximas do abrigo, maior a oferta de alimento e consequentemente, maior a população de $D$. rotundus que potencialmente viveria neste abrigo. O mesmo vale para o inverso: se um dado abrigo possuir poucas propriedades rurais em sua área de influência ou se estas estiverem distantes do abrigo, menor a seria a população de $D$. rotundus potencialmente vivendo neste abrigo. Vale ressaltar que esta capacidade de suporte potencial pode ser modulada pelo tipo de abrigo (natural ou artificial) e para tal, seria necessário um estudo para a determinação deste parâmetro, no campo.

Através da rede entre abrigos e propriedades rurais e formação de comunidades seria possível identificar propriedades rurais sobre maior risco para ocorrência de raiva dada a confirmação de circulação viral em uma dada comunidade de abrigos. Seria ainda possível, sob um sistema de vigilância ativo, priorizar a busca pela informação de agressões por morcegos hematófagos, nas propriedades rurais. O modelo mostra que propriedades rurais pertencentes a 
uma mesma comunidade estariam sob o mesmo risco de ocorrência de raiva, caso o vírus passe a circular na comunidade de abrigos que influencia a comunidade de propriedades rurais.

A rede entre abrigos e propriedades rurais poderiam ainda ser utilizada no sentido oposto. $O$ alicerce de construção desta rede é a formação de áreas de influência de abrigos. Na ocorrência de agressões em determinada propriedade rural, a exploração topográfica de curvas em mesmo nível ou superiores à da propriedade rural poderiam diminuir a área de procura por potenciais abrigos ativos de $D$. rotundus, orientando e otimizando a busca por abrigos não cadastrados e, por consequência, por fontes de transmissão do vírus da raiva.

A rede de abrigos poderia auxiliar a identificar nós (abrigos) cruciais (hubs) e de maior influência sobre a rede, cujo controle focalizado poderia interromper a circulação viral e impedir a dispersão do vírus. Sobre este ponto, a capacidade de suporte potencial quando aliada à rede entre abrigos, poderia não apenas determinar os abrigos de maior influência para a rede, como ainda estimar a população potencialmente encontrada nele. Isso auxiliaria muito na determinação da quantidade de morcegos que deveriam ser capturados com o intuito de promover o controle populacional daquele abrigo.

Não foi determinada a área contínua das comunidades de abrigos, pois o sistema de vigilância se dá nas propriedades rurais e na ocorrência de agressões e da raiva, então, a circulação da enfermidade nas comunidades de abrigos foi inferida pela sobreposição entre as duas redes.

O controle populacional de morcegos hematófagos é hoje, aliado à vacinação, o método de prevenção mais utilizado contra a raiva em herbívoros de interesse econômico. Entretanto, este controle deve ser preciso afim de impedir uma dispersão ainda maior do vírus piorando o cenário existente (BLACKWOOD et al., 2013). Como exemplificado no Capítulo 1, quaisquer mudanças ambientais, sejam nos nós da rede entre abrigos ou nos nós da entre entre abrigos e propriedades rurais, alteraria significativamente a rede. A rede tem, portanto, uma característica dinâmica, influenciada pelos nós e pelo ambiente que os cerca, que pode se refletir nas redes como um todo, nas comunidades e, em última instância, na transmissão da raiva.

A rede entre abrigos e propriedades rurais é do tipo direcionada, uma vez que apenas os nós representando os abrigos movimenta animais para as 
propriedades rurais, sendo estes os morcegos hematófagos. Para a rede entre abrigos entretanto, construímos uma rede não-direcionada. Porém, é de entendimento comum que os morcegos hematófagos realizam constantes movimentações entre os abrigos (NEUWEILER, 2000; KUNZ; FENTON, 2003), por exemplo, machos que deixam seus abrigos maternidades para formarem colonias satélites com outros machos, que por sua vez tentaram continuadamente regressar ao seu abrigo de origem ou a outros abrigos maternidades próximos para realizarem cópula. Sendo assim, a rede entre abrigos deveria ser do tipo direcionada, sendo influência por determinantes ainda não muito explorados.

Tais determinantes poderiam ser influênciados, por exemplo, pela oferta de alimento na área de uso do abrigo e número de abrigos vizinhos indicando seu grau de influência na rede. Sendo assim, abrigos maternidades seriam aqueles maior número de propriedades rurais em sua área de uso ou maior número de abrigos conectados à ele, ou ainda, determinado por uma associação destes.

Seria pertinente a continuação deste trabalho, incorporando determinantes relacionados aos aspectos biológicos do agente causador da doença e de aspectos ecológicos das interações entre morcegos hematófagos para manutenção do vírus, com o intuito de construção de um modelo de transmissão em redes de contato, capaz de prever situações e cenários para ocorrência e dispersão da raiva.

\subsection{Conclusões}

A análise de redes baseada na topografia e acessibilidade pode ser utilizada como método para análise de risco para ocorrência de mordeduras e casuística de raiva. Tal modelo permitirá a incorporação de um nível de precisão elevado na vigilância e no controle da raiva em herbívoros de interesse econômico.

O modelo construído permite identificar abrigos de maior importância para a rede entre abrigos responsável pela manutenção e transmissão do vírus da raiva, identificar as comunidades de propriedades rurais sob maior risco para ocorrência da raiva, auxiliar a direcionar a identificação de novos abrigos e por 
consequência, otimizar o controle e a prevenção da raiva em herbívoros de interesse econômico.

A incorporação destes modelos de redes a determinantes epidemiológicos da doença e do vírus da raiva poderiam originar um modelo matemático com um nível ainda maior de precisão, abrangendo a dinâmica da transmissão e dispersão do vírus da raiva entre populações de $D$. rotundus e destes para populações de herbívoros de interesse econômico.

\subsection{Referências}

BLACKWOOD, J. C.; STREICKER, D. G.; ALTIZER, S.; ROHANI, P. Resolving the roles of immunity, pathogenesis, and immigration for rabies persistence in vampire bats. Proc. Natl. Acad. Sci. U S A, v. 110 (51), p. 20837-20842, 2013.

BLONDEL; V.; GUILLAUME; J.; LAMBIOTTE; R.; MECH; E. Fast unfolding of communities in large networks. J Stat Mech, Theory Exp, 2008. Disponível em: http://findcommunities.googlepages.com.

BRAGA; G. B.; GRISI-FILHO; J. H. H.; LEITE; B. M.; SENNA; E. F.; DIAS; R. A. Predictive qualitative risk model of bovine rabies occurrence in Brazil. Prev Vet Med, v. 113, p. 536-546, 2014.

CARTER G.; LEFFER L. Social grooming in bats: are vampire bats exceptional? PIOS ONE, 2015.

CALISHER; C.; CHILDS; J.; FIELD; H.; HOLMES; K.; SCHOUNTZ; T. Bats: important reservoir hosts of emerging viruses. Clin Microbiol Rev, v. 19(3), p. 531-545, 2006.

Controle da raiva dos herbívoros. Ministério da Agricultura, Pecuária e Abastecimento, Secretaria de Defesa Agropecuária. Manual Técnico, Brasília, Distrito Federal, 2009. 
DIAS; R. A.; NOGUEIRA FILHO; V. S.; GOULART; C. S.; TELLES; I. C. O.; MARQUES; G. H. F.; FERREIRA; F.; AMAKU; M.; FERREIRA NETO; J. S. Modelo de risco para a circulação do vírus da raiva em herbívoros no Estado de São Paulo, Brasil. Rev Panam Salud Publica, v. 30(4), p. 370-376, 2011.

FERRARI, J. J. F.; BARROS, M. A.; GOMES, M. N.; SOUZA, M. C. A. M.; OLIVEIRA, R. N.; CRUZ, F. P. N.; MARRELLI, M. T. Análise da mudança da cobertura e uso da terra dos municípios de Jacareí e Santa Branca - SP como subsídio ao estudo das ocorrências de raiva transmitida por morcegos. Sociedade \& Natureza, v. 23, n. 2, 2011.

FORTUNATO; S. Community detection in graphs. Physics Reports, v. 486, no. 3-5, p. 75-174, 2010.

GEPHI. The Open Graph Viz Platform, 2017. Versão 0.9.2.

GREEN; D. M.; GREGORY; A.; MUNRO; L. A. Small- and large-scale network structure of live fish movements in Scotland. Preventive Veterinary Medicine, v. 91, no. 2-4, p. 261-269, 2009.

GRISI FILHO, J. H. H. Caracterização de circuitos pecuários com base em redes de movimentação de animais. 2012. 30 f. Tese (Doutorado em Ciências) - Faculdade de Medicina Veterinária e Zootecnia, Universidade de São Paulo, São Paulo, 2012.

HAYES; M. A.; PIAGGIO; A. J. Assessing the potential impacts of a changing climate on the distribution of a rabies virus vector. PIoS ONE. 2018.

KUNZ; T. H.; FENTON; M. B. Bat ecology. The University of Chicago Press. Chicago, 2003.

MEDINA A. M., HARVEY C. A., MERLO D. S., VÍLCHEZ S., HERNÁNDEZ B. Bat Diversity and Movement in an Agricultural Landscape in Matiguas, Nicaragua. Biotropica, v. 39(1), p. 120-128, 2007. 
Ministério da Agricultura, Pecuária e Abastecimento (MAPA). Controle da raiva em herbívoros: manual técnico. Brasília: MAPA, 2009.

MIALHE, P. J. Preferential prey selection by Desmodus rotundus (E. Geoffroy, 1810, Chiroptera, Phyllostomidae) feeding on domestic herbivores in the municipiality of São Pedro - SP. Brazilian Journal of Biology, v. 74, n. 3, p. 579584, 2014.

NEUWEILER, G. The biology of bats. Oxford University Press. New York, New York, 2000.

NEWMAN; M. E. J. Modularity and community structure in networks. PNAS, v. 103, no. 23, p. 8577-8582, 2006.

POLO; G.; MERA ACOSTA; C.; FERREIRA; F.; DIAS; R. A. Location-Allocation and Accessibility Models for Improving the Spatial Planning of Public Health Services. PLoS ONE, 10(3), 2015.

QGIS Desktop, 2017. Version 2.18.7.

R. Version 3.4.3, 2017.

RADKE; J.; MU; L. Spatial Decompositions, Modeling and Mapping Service Regions to Predict Access to Social Programs. Geographic Information Sciences, v. 6, i. 2, p. 105-112, 2009.

REEM, D. The geometric stability of Voronoi diagrams with respect to small changes of the sites. Proceedings of the 27th Annual ACM Symposium on Computational Geometry, p. 254-263, 2011.

U. S. GEOLOGICAL SURVEY. U. S. Department of the Interior. Disponível em: https://earthexplorer.usgs.gov/ . Acessado em: 18 de julho de 2018. 
VOIGT C. C.; KELM D. H. Host preference of the common vampire bat (Desmodus rotundus; Chiroptera) assessed by stable isotopes. Journal of Mammalogy, v. 87, i. 1, p. 1-6, 2006.

WILKINSON; G. S. The social Organization of the common vampire bat I: pattern and cause of association. Behaviol Ecology and Sociobiology, v. 17, n. 2, p.111-121, 1985.

WILKINSON; G. S.; CARTER; G. G.; BOHN; K. M.; ADAMS; D. M. Non-kin cooperation in bats. Phil. Trans. R. Soc. B, v. 371, 2016.

ZHOU, T.; REN, J.; MEDO, M.; ZHANG, Y. Bipartite network projection and personal recommendation. Physical Review E, v. 76, i. 4, 2007. 


\section{CONSIDERAÇÕES FINAIS}

Iniciamos o trabalho avaliando e testando as possibilidades de uso da telemetria não apenas a nível da vigilância da transmissão da raiva, mas sobretudo dos aspectos biológicos do morcego Desmodus rotundus.

Os achados e hipóteses levantadas com o trabalho de telemetria evidenciaram a relação entre topografia com a escolha das propriedades rurais a serem utilizadas como fontes de alimentação, além de evidenciar questões comportamentais sobre a diminuição da competição no forrageamento, havendo escalonamento de morcegos de um mesmo abrigo no forrageio em uma dada propriedade rural.

Estes achados sedimentaram toda a base de premissas utilizadas para construção dos modelos de rede, juntamente com as informações disponíveis na literatura e dos dados de vigilância, que demonstrou como determinantes geográficos e topográficos influenciam a dinâmica territorial do $D$. rotundus.

A incorporação futura de determinantes biológicos da raiva e sua relação com determinantes ecológicos dos morcegos hematófagos poderão gerar um modelo matemático com maior nível de detalhamento, que abarque a dinâmica da transmissão e dispersão do vírus da raiva entre populações de $D$. rotundus e destes para populações de herbívoros de interesse econômico.

Apesar de todo o conhecimento empírico e científico construído após muitos anos de trabalho sobre a raiva, ainda há lacunas na compreensão sobre como a ecologia dos transmissores e do agente infeccioso estão diretamente ligados ao ambiente que coabitam com o homem e os animais domésticos, em parte, sanadas pelo presente trabalho.

\section{REFERÊNCIAS}

AMELON, S. K.; DALTON, D. C.; MILLSPAUGH, J. J.; WOLF, S. A. Radiotelemetry. Kunz, H.; Parsons, S. Ecological and behavioral methods for the study of bats, 2 ed., Johns Hopkins University Press, Baltimore, Maryland, 2009. 
BAQUERO, O. S.; MARQUES, F. S. EpiDynamics: Dynamic Models in Epidemiology. R package version 0.3.0.

BELOTTO, A.; LEANES, L. F.; SCHNEIDER, M. C.; TAMAYO, H.; CORREA, E. Overview of rabies in the Americas. Virus Research, v. 111, n. 4, p. 5-12, 2005.

BELWOOD, J. J.; MORTON, P.A. Vampires: The real story. Viruses, v. 6, p. 1911-1928, 2014.

BLACKWOOD, J. C.; STREICKER, D. G.; ALTIZER, S.; ROHANI, P. Resolving the roles of immunity, pathogenesis, and immigration for rabies persistence in vampire bats. Proc. Natl. Acad. Sci. U S A, v. 110 (51), p. 20837-20842, 2013.

BLONDEL, V.; GUILLAUME, J.; LAMBIOTTE, R.; MECH, E. Fast unfolding of communities in large networks. J Stat Mech, Theory Exp, 2008. Disponível em: http://findcommunities.googlepages.com.

BRAGA, G. B.; GRISI-FILHO, J. H. H.; LEITE, B. M.; SENNA, E. F.; DIAS, R. A. Predictive qualitative risk model of bovine rabies occurrence in Brazil. Prev Vet Med, v. 113, p. 536-546, 2014.

BRASIL. Instrução normativa 5, de 01 de março de 2002. Aprova normas técnicas para o controle da raiva de herbívoros. Diário Oficial [da] União, Brasília, 04 mar. 2002, Seção 1.

BRASIL. Portaria SDA 168, de 27 de setembro de 2005. Aprova o manual técnico normas técnicas para o controle da raiva de herbívoros. Diário Oficial [da] União, Brasília, 29 dez. 2005, Seção 1.

BRASIL. Ministério da Agricultura, Pecuária e Abastecimento, Secretaria de Defesa Agropecuária. Controle da Raiva em Herbívoros. Brasília, DF, 2009.

BREDT, A.; ARAUJO, F. A.; CAETANO, J. R. J.; RODRIGUES, M. G. R.; YOSHIKAWA, M.; SILVA, M. M. S. Morcegos em áreas urbanas e rurais: 
Manual de manejo e controle. Brasilia: Ministerio da Saude, Fundação Nacional de Saude, p. 72, 1998.

CALISHER, C.; CHILDS, J.; FIELD, H.; HOLMES, K.; SCHOUNTZ, T. Bats: important reservoir hosts of emerging viruses. Clin Microbiol Rev, v. 19(3), p. 531-545, 2006.

CAMPBELL, A. L.; NAIK, R. R.; SOWARDS, L.; STONE, M. O. Biological infrared imaging and sensing. Micron, v. 33, p. 211-225, 2002.

CARINI, A. Sur une grande epizootie de rage. Annales Institut Pasteur Paris, v. 25, p. 843-856, 1911.

CARTER, G.; LEFFER, L. Social grooming in bats: are vampire bats exceptional? PloS ONE, 2015.

CARTER, G. G.; LOGSDON, R.; ARNOLD, B. D.; MENCHACA, A.; MEDELLIN, R. A. Adult Vampire Bats Produce Contact Calls When Isolated: Acoustic Variation by Species, Population, Colony, and Individual. PIoS ONE, 2012.

CARTER, G. G.; FORSS, S.; PAGE, R. A.; RATCLIFFE, J. M. Younger vampire bats (Desmodus rotundus) are more likely than adults to explore novel objectives. PloS ONE, v. 13, i. 5, 2018.

CONDORI-CONDORI, R. E.; STREICKER, D. G.; CABEZAS-SANCHEZ, C.; VELASCO-VILLA, A. Enzootic and epizootic rabies associated with vampire bats, Peru. Emerging Infectious Diseases, v. 24, n. 5, 2018.

CONSTANTINE, D. G. Activity patterns of the Mexican free-tailed bat. University of New Mexico Publications in Biology, v. 7, p. 1-79, 1967.

CONSTANTINE, D. G.; TIERKEL, E. S.; KLECKNER, M. D.; HAWKINS, D. M. Rabies in New Mexico cavern bats. Public Health Reports, v. 83, p. 303-316, 1968. 
CRICHTON, E. G.; KRUTZSCH, P. H. Reproductive biology of bats. Academic Press, 2000.

DELPIETRO, H. A.; RUSSO, R. G.; CARTER, G. G.; LORD, R. D.; DELPIETRO, G. L. Reproductive seasonality, sex ratio and philopatry in Argentina's common vampire bats. R. Soc. open sci, v. 4, 2017.

DIAS, R. A.; NOGUEIRA FILHO, V. S.; GOULART, C. S.; TELLES, I. C. O.; MARQUES, G. H. F.; FERREIRA, F.; AMAKU, M.; FERREIRA NETO, J. S. Modelo de risco para a circulação do vírus da raiva em herbívoros no Estado de São Paulo, Brasil. Rev Panam Salud Publica, v. 30(4), p. 370-376, 2011.

EARTHEXPLORER. U. S. GEOLOGICAL SURVEY, U. S. Department of the Interior. Disponível em: https://earthexplorer.usgs.gov/. Acessado em: 18 de julho de 2018.

FENTON, M. B. Questions, ideas and tools: lessons from bat echolocation. Animal Bahaviour, v. 85, p. 869-879, 2013.

FERRARI, J. J. F.; BARROS, M. A.; GOMES, M. N.; SOUZA, M. C. A. M.; OLIVEIRA, R. N.; CRUZ, F. P. N.; MARRELLI, M. T. Análise da mudança da cobertura e uso da terra dos municípios de Jacareí e Santa Branca - SP como subsídio ao estudo das ocorrências de raiva transmitida por morcegos. Sociedade \& Natureza, v. 23, n. 2, 2011.

FORTUNATO, S. Community detection in graphs. Physics Reports, v. 486, no. 3-5, p. 75-174, 2010.

FREITAS, M. B.; QUEIROZ, J. F.; DIAS GOMES, C. I.; COLLARES-BUZATO, C. B.; BARBOSA, H. C.; BOSCHERO, A. C.; GONÇALVES, C. A.; PINHEIRO, E. $C$. Reduced insulin secretion and glucose intolerance are involved in the fasting susceptibility of common vampire bats. General and Comparative Endocrinology, v. 183, p. 1-6, 2013. 
GEPHI. The Gephi Consortium, versão 0.9.2, 2017.

GOMES, M. N.; UIEDA, W. Abrigos diurnos, composição de colônias, dimorfismo sexual e reprodução do morcego hematófago Desmodus rotundus (E. Geoffroy) (Chiroptera, Phyllostomidae) no Estado de São Paulo, Brasil. Rev. Bras. Zool. v. 21, n. 3, 2004.

GREEN, D. M.; GREGORY, A.; MUNRO, L. A. Small- and large-scale network structure of live fish movements in Scotland. Preventive Veterinary Medicine, v. 91, no. 2-4, p. 261-269, 2009.

GREENHALL, A. M. Feeding behavior. In: Greenhall A. M., Schmidt U. (eds) Natural history of vampire bats. CRC Press. Florida, p. 111-131, 1988.

GRISI FILHO, J. H. H. Caracterização de circuitos pecuários com base em redes de movimentação de animais. 2012. 30 f. Tese (Doutorado em Ciências) - Faculdade de Medicina Veterinária e Zootecnia, Universidade de São Paulo, São Paulo, 2012.

HAYES, M. A.; PIAGGIO, A. J. Assessing the potential impacts of a changing climate on the distribution of a rabies virus vector. PIoS ONE. 2018.

KUNZ, T. H.; FENTON, M. B. Bat ecology. The University of Chicago Press. Chicago, 2003.

KUNZ, T. H.; HODGKISON, R.; WEISE, C. D. Methods of capturing and handling bats. Kunz H., Parsons S. (eds.). Ecological and behavioral methods for the study of bats, 2 ed., Johns Hopkins University Press, Baltimore, Maryland, 2009.

MACEDO, C. I.; CARNIELI JR., P.; BRANDÃO, P. E.; ROSA, E. S. T.; OLIVEIRA, R. N.; CASTILHO, J. G.; MEDEIROS, R.; MACHADO, R. R.; OLIVEIRA, R. C.; CARRIERI, M. L.; KOTAIT, I. Diagnosis of human rabies cases by polymerase chain reaction of neck-skin samples. The Brazilian Journal of Infectious Diseases, v. 10, n. 5, p. 341-345, 2006. 
MCCRACKEN, G. F.; WILKINSON, G. S. Bat mating system. In: CRICHTON, E. G.; KRUTZSCH, P. H. Reproductive biology of bats. Academic Press, 2000. cap. 8, p 321-357.

MEDINA, A. M.; HARVEY, C. A.; MERLO, D. S.; VÍLCHEZ, S.; HERNÁNDEZ, B. Bat Diversity and Movement in an Agricultural Landscape in Matiguas, Nicaragua. Biotropica, v. 39(1), p. 120-128, 2007.

MIALHE, P. J. Preferential prey selection by Desmodus rotundus (E. Geoffroy, 1810, Chiroptera, Phyllostomidae) feeding on domestic herbivores in the municipiality of São Pedro - SP. Brazilian Journal of Biology, v. 74, n. 3, p. 579584, 2014.

Ministério da Agricultura, Pecuária e Abastecimento (MAPA). Controle da raiva em herbívoros: manual técnico. Brasília: MAPA, 2009.

NEUWEILER, G. The biology of bats. Oxford University Press. New York, New York, 2000.

NEWMAN, M. E. J. Modularity and community structure in networks. PNAS, v. 103, no. 23, p. 8577-8582, 2006.

Package ‘Rmark'. R Code for Mark Analysis, versão 2.2.4, 2017.

PEDROSA, F.; SALERNO, R.; PADILHA, F. V. B.; GALETTI, M. CUrrent distribution of invasive feral pigs in Brazil: economic impacts and ecological uncertainty. Brazilian Journal of Nature Conservation, v. 13, p. 84-87, 2015

PIAGGIO, A. J.; RUSSEL, A. L.; OSORIO, I. A.; RAMÍREZ, A. J.; FISCHER, J. W.; NEUWLAD, J. L.; TIBBLES, A. E.; LEUCONA, L.; MCCRACKEN, G. F. Genetic demography at the leading edge of the distribution of a rabies virus vector. Ecology and Evolution, v. 7, p. 5343-5351, 2017. 
POLO, G.; MERA ACOSTA, C.; FERREIRA, F.; DIAS, R. A. Location-Allocation and Accessibility Models for Improving the Spatial Planning of Public Health Services. PLoS ONE, v. 10, n. 3, 2015.

POLLOCK, K. H.; ALPIZAR-JARA, R. Classical Open-population CaptureRecapture Models. Amstrup S. C., McDonald T. L., Manly B. F. J. (eds.). Handbook of capture-recapture analysis, Princeton University Press, Princeton, New Jersey, 2005.

QGIS Desktop. QGIS Project, versão 2.18.7, 2017.

R. The R Foundation, versão 3.4.3, 2017.

RADKE; J.; MU; L. Spatial Decompositions, Modeling and Mapping Service Regions to Predict Access to Social Programs. Geographic Information Sciences, v. 6 , i. 2 , p. $105-112,2009$

REEM, D. The geometric stability of Voronoi diagrams with respect to small changes of the sites. Proceedings of the 27th Annual ACM Symposium on Computational Geometry, p. 254-263, 2011.

REIS, N. R.; PERACCHI, A. L.; PEDRO, W. A.; LIMA, I. P. Morcegos do Brasil. Universidade Estadual de Londrina. Londrina, 2007.

RISKIN, D. K; PARSONS, S.; SCHUTT, W. A.; CARTER, G. G.; HERMANSON, J. W. Terrestrial locomotion of the New Zealand short-tailed bat Mystacina tuberculata and the common vampire bat Desmodus rotundus. The Journal of Experimental Biology, v. 209, p. 1725-1736, 2006.

SÁNCHEZ-HERNÁNDEZ, C.; ROMERO-ALMARAZ, M. L.; WOOTEN, M. C.; SCHNELL, G. D.; KENNEDY, M. L. Speed in flight of common vampire bats (Desmodus rotundus). The Southwestern Naturalist, v. 51, n. 3, p. 422-425, 2006. 
SEMINÁRIO DE VIGILÂNCIA E CONTROLE DA RAIVA NO ESTADO DE SÃO PAULO. 10 ed. 2017. São Paulo. Situação Epidemiológica da Raiva no Brasil. Disponível em: $\quad$ http://www.saude.sp.gov.br/resources/institutopasteur/pdf/wrd/2017/palestras/situacaoepidemiologicadaraivanobrasil2017andreperes02out17.pdf. Acessado em 24 de Abril de 2018.

SILVIS, A.; FORD, W. M.; BRITZKE, E. R.; JOHNSON, J. B. Association, roost use and simulated disruption of Myotis septentrionalis maternity colonies. Behavioural processes, v. 103, p. 283-290, 2014.

SHADMEHR, R.; HUANG, H. J.; AHMED, A. A. A representation of effort in decision-making and motor control. Current Biology, n. 26, p. 1929-1934, 2016.

UIEDA, W. Morcegos hematófagos e a raiva em herbívoros no Brasil. Anais do seminário de Ciências da Faculdades Integradas de Uberaba nov 5-9. Uberaba, Brazil, Minas Gerais: FIUBE. P. 13-29, 1987.

VOIGT, C. C.; KELM, D. H. Host preference of the common vampire bat (Desmodus rotundus; Chiroptera) assessed by stable isotopes. Journal of Mammalogy, v. 87, i. 1, p. 1-6, 2006.

WILKINSON, G. S. The social Organization of the common vampire bat I: pattern and cause of association. Behaviol Ecology and Sociobiology, v. 17, n. 2, p.111-121, 1985.

WILKINSON, G. S.; CARTER, G. G.; BOHN, K. M.; ADAMS, D. M. Non-kin cooperation in bats. Phil. Trans. R. Soc. B, v. 371, 2016.

WHO Expert Consultation on Rabies, 2 ed. WHO Technical Report Series, no. 982. World Health Organization, 2013.

ZHOU, T.; REN, J.; MEDO, M.; ZHANG, Y. Bipartite network projection and personal recommendation. Physical Review E, v. 76, i. 4, 2007. 